\title{
Conversion of Environmental Data to a Digital-Spatial Database, Puget Sound Area, Washington
}

By Mark A. Uhrich and Timothy S. McGrath

\section{U.S. GEOLOGICAL SURVEY}

Open-File Report 95-359

Prepared in cooperation with the

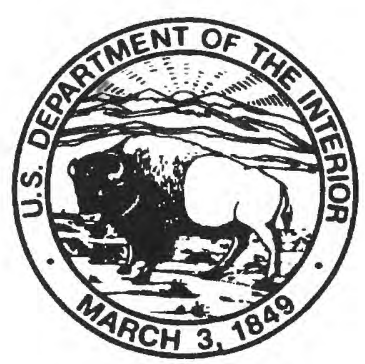
PUGET SOUND WATER QUALITY AUTHORITY 


\title{
U. S. DEPARTMENT OF THE INTERIOR BRUCE BABBITT, Secretary
}

\author{
U.S. GEOLOGICAL SURVEY \\ GORDON P. EATON, Director
}

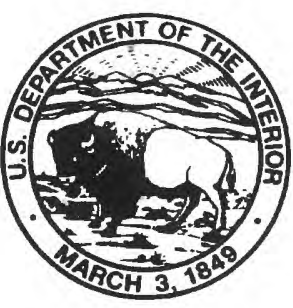

Any use of trade, product, or firm names in this publication is for descriptive purposes only and does not imply endorsement by the U.S. Government.

For additional information write to:

District Chief

U.S. Geological Survey, WRD 10615 S.E. Cherry Blossom Drive Portland, OR 97216
Copies of this report can be purchased from:

U.S. Geological Survey Branch of Information Services Box 25286, Federal Center Denver, CO 80225 


\section{CONTENTS}

Abstract

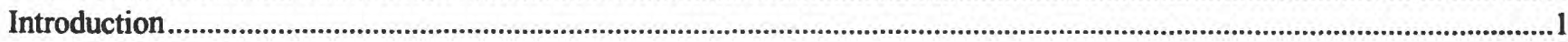

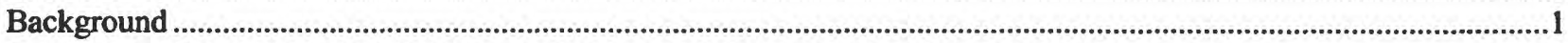

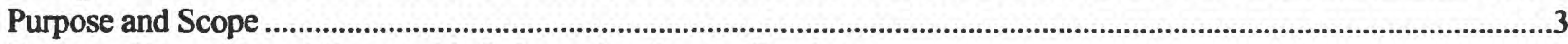

Design of Puget Sound Geographic Information System Database ....................................................................................3

Data Layers from Sources Other Than the Puget Sound Environmental Atlas ..........................................................................4

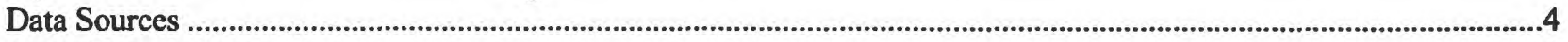

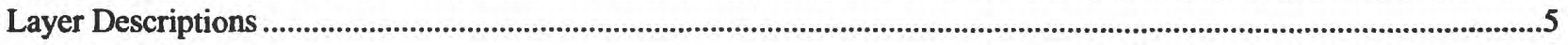

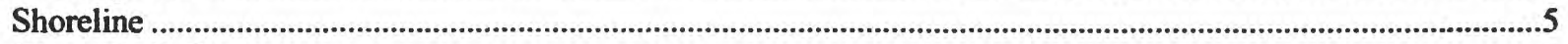

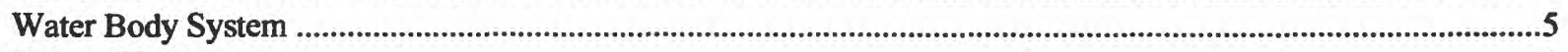

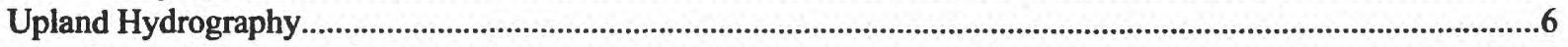

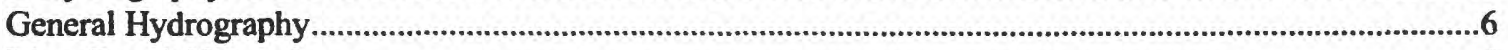

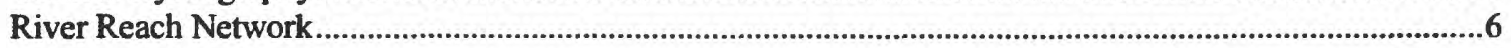

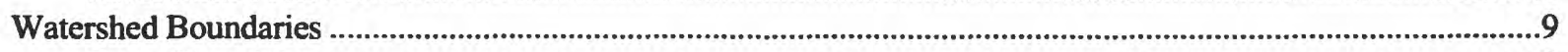

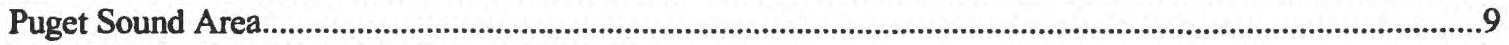

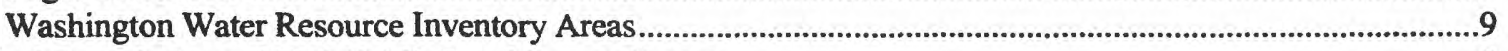

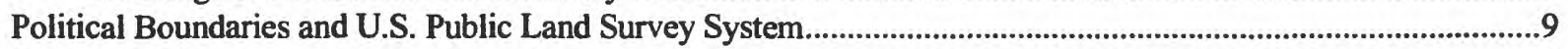

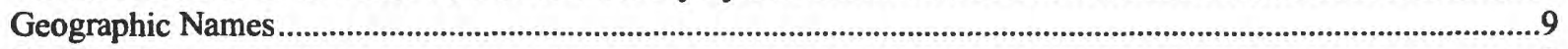

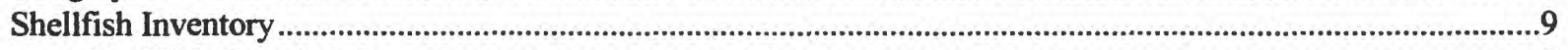

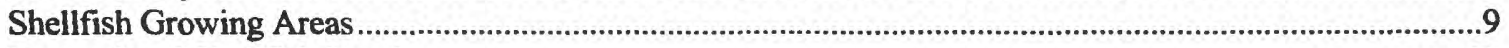

Recreational Shellfish Beaches ................................................................................................................... 13

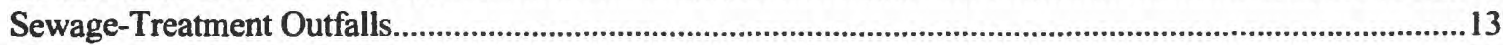

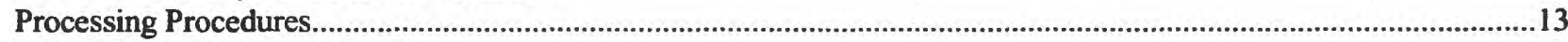

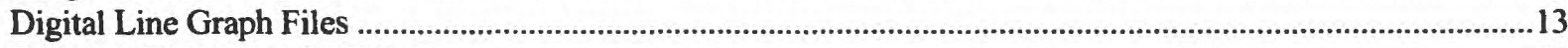

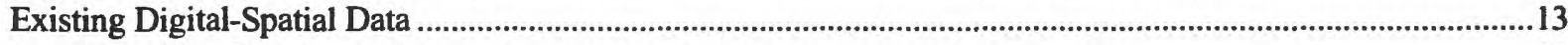

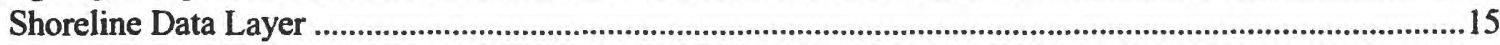

Upland Hydrography Data Layer.............................................................................................................15

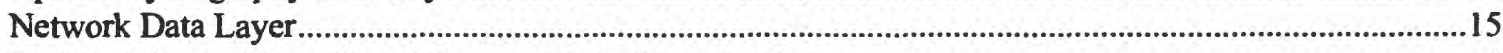

Data Digitized for the Puget Sound Geographic Information System ...............................................................15

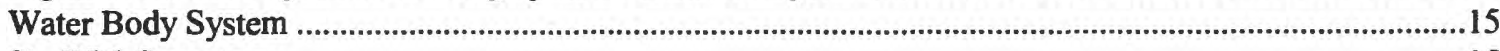

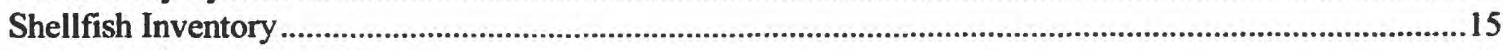

Puget Sound Environmental Atlas Data Layers............................................................................................................16

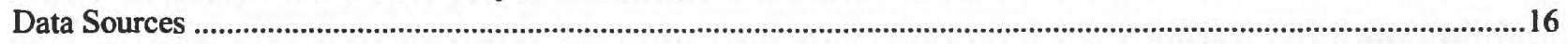

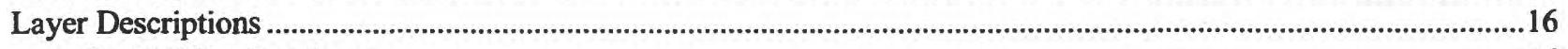

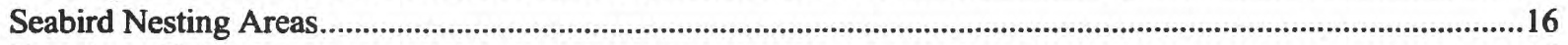

Nearshore Habitat

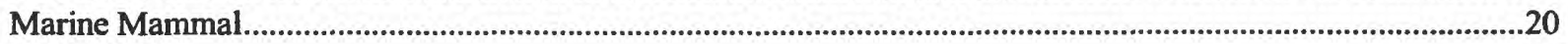

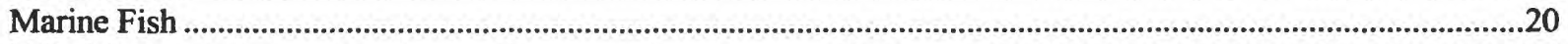

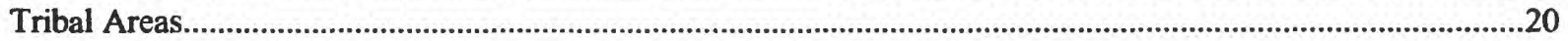

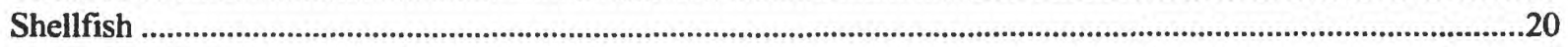

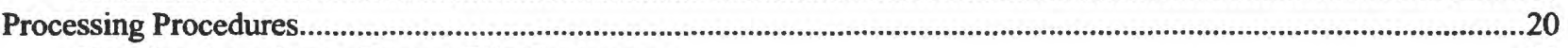

Drawing Interchange Format File Conversion................................................................................................20

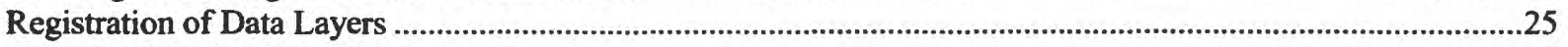

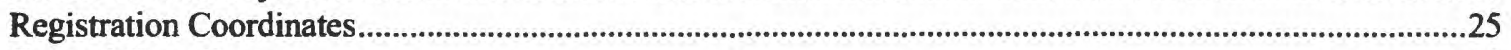

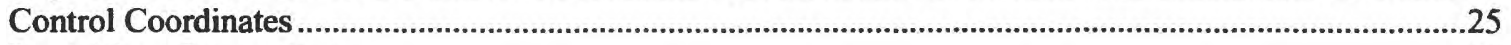

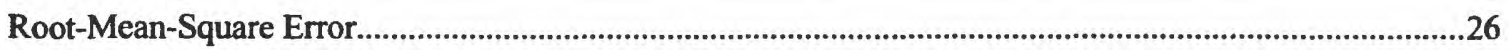

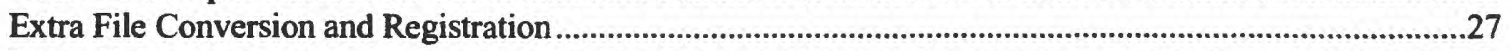

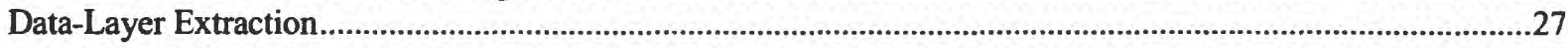

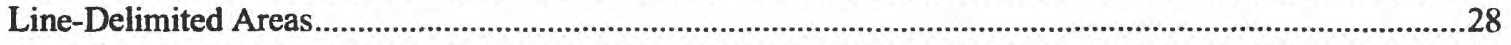

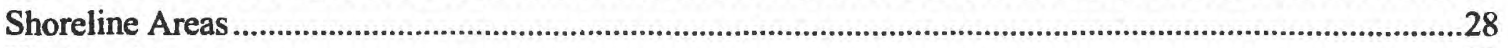

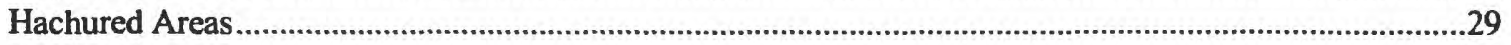

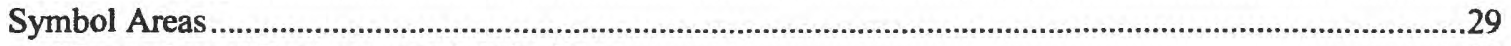

Compilation of Puget Sound Environmental Atlas Data ........................................................................................29 


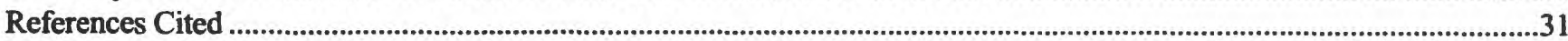

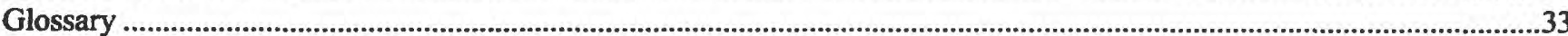

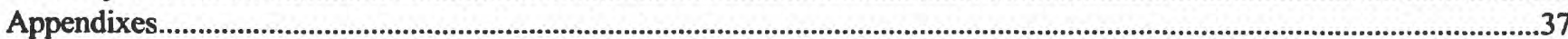

Appendix A: Data-Layer Dictionary of Environmental Data for the Puget Sound Area from Sources

Other Than the Puget Sound Environmental Atlas. .41

Appendix B: Data-Layer Dictionary of the Puget Sound Environmental Atlas .............................................................67

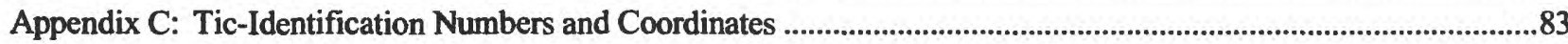

Appendix D: Root-Mean-Square Error for Base and Extra Drawing Interchange Format File Conversion ..................89

Appendix E: ARC/INFO Hachure Processing Commands.

\section{FIGURES}

1.- 13. Maps showing:

1. Location of the Puget Sound project area. .2

2. Puget Sound shoreline and embayments from digital data .......................................................................................

3. General hydrography data layer with the Puget Sound shoreline.....................................................................8

4. U.S. Geological Survey hydrologic unit boundaries for the Puget Sound area...................................................10

5. Washington Department of Ecology water-resource inventory areas for the Puget Sound Basin .......................11

6. Shellfish growing areas from the Washington Department of Health 1990 Shellfish Inventory ........................112

7. Sewage-treatment outfalls and recreational shellfish beaches from the Washington Department of Health 1990 Shellfish Inventory

8. Digitized locations of seabird nesting areas for selected species ........................................................................18

9. Digitized locations of kelp and eelgrass beds larger than one acre ....................................................................19

10. Marine mammal digital points for selected species...........................................................................................21

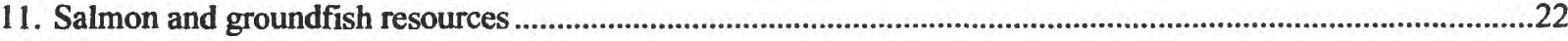

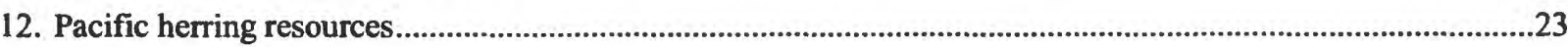

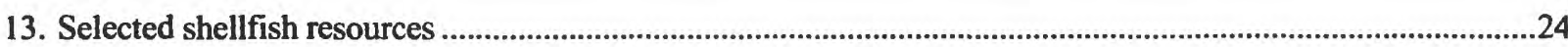

14. Graph showing root-mean-square error for Base and Extra DXF (Drawing Interchange Format)

file transformation

\section{TABLES}

1. Data sources other than the Puget Sound Environmental Atlas used for the Puget Sound Geographic Information System.

2. List of Puget Sound Basin 1:100,000-scale U.S. Geological Survey topographic maps . .5

3. Resource name, source agency, and date of data that were collected for the Puget Sound Geographic Information System from sources other than the Puget Sound Environmental Atlas.

4. Data layers, resource layers, and definitions of the Puget Sound Environmental Atlas

5. Root-mean-square error, in meters, for data transformation to three projection systems in the Puget Sound Environmental Atlas, Regions 5 and 6

6. Root-mean-square error, in meters, for latitude/longitude tics on Puget Sound Environmental Atlas regional maps 


\title{
Conversion of Environmental Data to a Digital-Spatial Database, Puget Sound Area, Washington
}

\author{
By Mark A. Uhrich and Timothy S. McGrath
}

\section{Abstract}

Data and maps from the Puget Sound Environmental Atlas, compiled for the U.S. Environmental Protection Agency, the Puget Sound Water Quality Authority, and the U.S. Army Corps of Engineers, have been converted into a digitalspatial database using a geographic information system. Environmental data for the Puget Sound area, collected from sources other than the Puget Sound Environmental Atlas by different Federal, State, and local agencies, also have been converted into this digital-spatial database. Background on the geographic-information-system planning process, the design and implementation of the geographic information-system database, and the reasons for conversion to this digital-spatial database are included in this report.

The Puget Sound Environmental Atlas data layers include information about seabird nesting areas, eelgrass and kelp habitat, marine mammal and fish areas, and shellfish resources and bed certification. Data layers, from sources other than the Puget Sound Environmental Atlas, include the Puget Sound shoreline, the water-body system, shellfish growing areas, recreational shellfish beaches, sewage-treatment outfalls, upland hydrography, watershed and political boundaries, and geographic names. The sources of data, descriptions of the data layers, and the steps and errors of processing associated with conversion to a digital-spatial database used in development of the Puget Sound Geographic Information System also are included in this report. The appendixes contain data dictionaries for each of the resource layers and error values for the conversion of Puget Sound Environmental Atlas data.

\section{INTRODUCTION}

\section{Background}

The Puget Sound Environmental Atlas (PSEA), published by the U.S. Environmental Protection Agency, the Puget Sound Water Quality Authority, and the U.S. Army Corps of Engineers, provides a common source of collected maps and a cartographic base for natural and human-made features that define or affect available marine and nearshore aquatic and avian resources in the Puget Sound area, Washington (EvansHamilton, Inc., and D.R. Systems, Inc., 1987). The PSEA was prepared in digital format and compiled using CAD/CAM software. However, the graphic files produced are not directly usable with a geographic information system (GIS) because each file is independent of the other files and, therefore, cannot be combined for analyses or used in a relational database.

The Puget Sound is located in the northwestern United States, between latitudes $47^{\circ} \mathrm{N}$ and $49^{\circ} \mathrm{N}$, and longitudes $124^{\circ} \mathrm{W}$ and $122^{\circ} \mathrm{W}$. The PSEA divides the Puget Sound into 12 geographic regions, each displayed as a separate set of maps for the various resources. Four scales were used for these regional maps. Additionally, only the estuarine areas of the Puget Sound were covered by the PSEA. A generalized map of the project area, which includes the drainage boundary and hydrography of the Puget Sound area, is shown on figure 1 . 


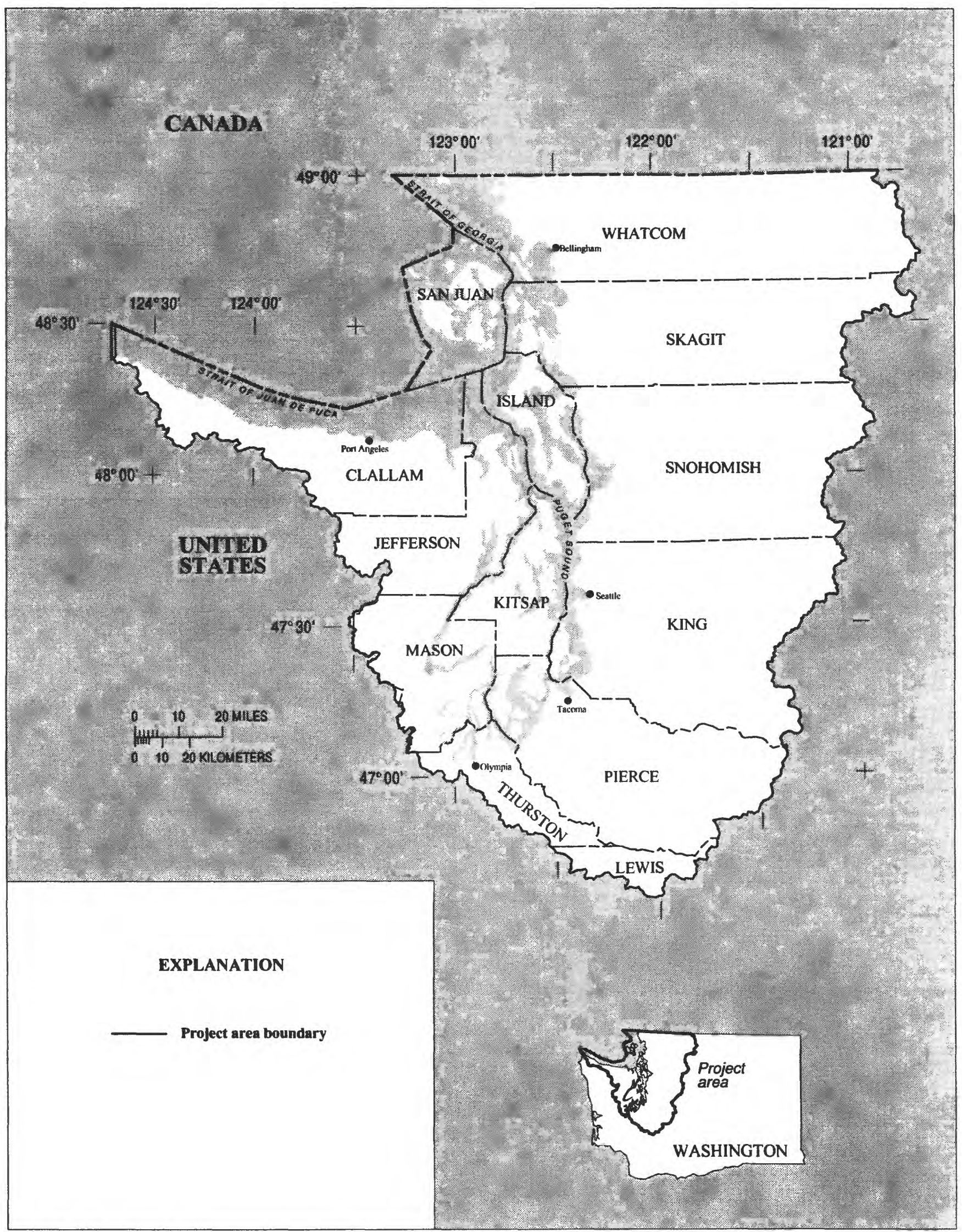

Base map from U.S. Geological Survey

1:100,000 Digital Line Graphs, 1989a.

Figure 1. Location of the Puget Sound project area. 
The Puget Sound Water Quality Authority adopted a recommendation (Puget Sound Water Quality Authority, 1990) to create a Puget Sound Geographic Information System (PSGIS). On the basis of that recommendation, a Puget Sound Water Quality Authority work group was formed to assess the user needs and potential applications of the available GIS data. To address the need for an integrated GIS, the U.S. Geological Survey, in cooperation with the Puget Sound Water Quality Authority, developed a digital-spatial database and converted appropriate PSEA data into a GIS-compatible format. Additional upland hydrography, basin and resource boundaries, and environmental data for the Puget Sound area from sources other than the PSEA were added to the PSGIS database. This expanded database provided those agencies responsible for managing the water resources of Puget Sound (Puget Sound Water Quality Authority, 1991) a versatile, digital-spatial database of common reference for analyzing geographic information. This report documents the methods used for developing the PSGIS digital-spatial database.

\section{Purpose and Scope}

This report documents the methods used to develop the PSGIS digital-spatial database. It describes the process of converting paper planimetric maps to a digital-spatial format. The method of converting PSEA data first to CAD/CAM files and then into GIS coverages is discussed. The procedure of digitizing or acquiring data from sources other than the PSEA and converting them directly to the PSGIS projection is also described. Database development, accomplished by linking the geographic data to attribute information, is documented for each data layer.

Although the PSEA covers the entire drainage of the Puget Sound area, this report principally concerns the marine-water part of the Puget Sound. The data layers created include all elements of a spatial database, such as lines, polygons and points, as well as the tabular information (attributes) associated with each resource. In this report, the digital conversion of Puget Sound environmental data is divided into two categories: data obtained from the PSEA, and environmental data for the Puget Sound area that were obtained from other sources (non-PSEA data). Included for each category of data is a description of each layer; an index of data sources; and a description of processing and registration procedures and problems, as well as projection errors. Data-layer dictionaries and attribute definitions appear in Appendix A for non-PSEA data and in Appendix B for PSEA data.

\section{Design of Puget Sound Geographic Information System Database}

Representatives from Federal and State agencies, private firms, and Native American Indian Tribes in the area participated in the design of the PSGIS database. These representatives met several times during the pilot phase of the project to discuss priorities of data types, as well as issues of design and implementation. Initially, parts of the original CAD/CAM database were converted from Intergraph software format into ARC/INFO format - the software chosen for the PSGIS database. Data were edited to conform with the data requirements specified by the Puget Sound Water Quality Authority and the U.S. Geological Survey (Puget Sound Water Quality Authority, 1990).

The PSGIS database was designed to conform to a 1:100,000-scale resolution $(100 \mathrm{~K})$ in a Universal Transverse Mercator (UTM) State Plane, Zone 10, coordinate system. Conversion limitations resulted from coordinate transfer and registration of data layers originally in Intergraph format to data layers in ARC/INFO format. Those conversion limitations have been documented in this report (see "Processing Procedures"). Transformation and conversion problems were insignificant and within National Mapping Accuracy Standards for other than PSEA data and were not addressed. The sources and dates of data are listed for both PSEA and non-PSEA categories.

Another aspect of the PSGIS design was to create a database in which data layers could be updated easily by the agency responsible for that information. For example, the Shellfish Inventory data layer is updated annually by the Washington Department of Health Shellfish Programs (Washington Department of Health, 1990). One method used to facilitate PSGIS database updates was the use of attribute names that correspond to each classification status within the Shellfish Inventory. By choosing that attribute name, each classification status layer easily could be selected and edited. Also, the Puget Sound Water Quality Authority requested additional attribute names that could be populated at a later date for resource-management options. 
These additional attribute names, COMMERCIAL, RECREATIONAL, POTENTIAL_COM, NONE, and UNKNOWN, were added to the marine and shellfish data layers to facilitate future updates. Finally, all the PSGIS data layers were designed to match the topological representations in the PSEA.

The PSGIS project was developed in two phases. In the pilot phase, database organization and the conversion of data sources within Region 6 of the PSEA were tested. The pilot phase involved converting designated layers of PSEA data, editing map features and attributes, and creating a database using converted PSEA data and non-PSEA data.

The second phase was designed to evaluate the prototype database developed by the joint Puget Sound Water Quality Authority and GIS work group. The data layers for the remaining 11 PSEA regions were converted and additional non-PSEA data were incorporated to create the PSGIS.

\section{DATA LAYERS FROM SOURCES OTHER THAN THE PUGET SOUND ENVIRONMENTAL ATLAS}

The PSGIS database includes seven categories of data layers from non-PSEA sources. These seven categories constitute a diverse group of information, which reflects the wide participation by Puget Sound area agencies and provides a complete background of all Puget Sound environmental resources. Fifteen digital coverages were created, 13 of which are described in this report. These 13 digitized layers include data for the Puget Sound shoreline, the Washington Department of Ecology embayments, the status and use of shellfish areas and recreational beaches, and data for sewage-treatment outfalls. The PSEA also includes layers of upland hydrography, watershed boundaries, political boundaries, and geographic names.

The final data-set products and attribute-field definitions were created with the DOCUMENT command, a user-contributed function to the ARC/INFO library (D.D. Nebert, U.S. Geological Survey, written commun., 1991). All documentation of sources used for the "Data-Layer Dictionary of Environmental Data for the Puget Sound Area from Sources Other Than the Puget Sound Environmental Atlas" is contained in Appendix A.

\section{Data Sources}

A wide variety of non-PSEA information sources also were used to establish the PSGIS database. Primary information sources, those individual agencies that originated and generated non-PSEA data, are listed in table 1 . In some cases, non-PSEA data layers were

Table 1. Data sources other than the Puget Sound Environmental Atlas used for the Puget Sound Geographic Information System

\begin{tabular}{|c|c|c|c|}
\hline $\begin{array}{l}\text { Agency } \\
\text { number }\end{array}$ & $\begin{array}{l}\text { Agency } \\
\text { label }\end{array}$ & $\begin{array}{l}\text { Agency } \\
\text { name }\end{array}$ & $\begin{array}{l}\text { Data } \\
\text { type }\end{array}$ \\
\hline 1 & NOAA-data & $\begin{array}{l}\text { National Oceanic and Atmospheric } \\
\text { Administration }\end{array}$ & Bathymetric survey \\
\hline 2 & NOAA-chart & $\begin{array}{l}\text { National Oceanic and Atmospheric } \\
\text { Administration }\end{array}$ & Nautical chart \\
\hline 3 & USGS-NMD & $\begin{array}{l}\text { U.S. Geological Survey, } \\
\text { National Mapping Division }\end{array}$ & Digital line graphs \\
\hline 4 & USGS-WRD & $\begin{array}{l}\text { U.S. Geological Survey, } \\
\text { Water Resources Division }\end{array}$ & $\begin{array}{l}\text { River-reach } \\
\text { digital data }\end{array}$ \\
\hline 5 & WDNR & $\begin{array}{l}\text { Washington Department of } \\
\text { Natural Resources, Aquatic Resources }\end{array}$ & $\begin{array}{l}\text { Water Resource } \\
\text { Inventory Areas }\end{array}$ \\
\hline 6 & WDOE & Washington Department of Ecology & Water body system \\
\hline 7 & WDOH & Washington Department of Health & Shellfish inventory \\
\hline
\end{tabular}


obtained from a secondary source because that data layer information already was available in ARC/INFO format, as was the case with the Geographic Name Information System and the River Reach data.

The original $100 \mathrm{~K}$-scale topographic maps, from which the hydrography, boundary, and U.S. Public Land Survey System data were scanned or digitized to create the Digital Line Graph (DLG) files, are listed in table 2. A list of non-PSEA agencies, resources and respective data-layer names, and the dates or ranges of dates indicating the original period of information are shown in table 3.

\section{Layer Descriptions}

\section{Shoreline}

The Puget Sound shoreline data layer, an essential part of the PSGIS database, functions as a reference data layer and template for other data layers, such as embayments and usual and accustomed Tribal fisheries, and includes some data layers from the Washington Department of Health Shellfish Inventory.

The U.S. Geological Survey National Mapping Division 100K-scale hydrography in DLG format (U.S. Geological Survey, 1989a) was projected in UTM and used as the source for the shoreline. The shoreline data layer covers the Puget Sound and the
Strait of Juan de Fuca coastline (fig. 2), but does not extend into Canada. The lines delineating the shoreline are a mean high-tide line from the $100 \mathrm{~K}$-scale topographic maps.

The shoreline data were extracted from the Pacific Northwest River Reach data set (Fisher, 1996). The U.S. Environmental Protection Agency River Reach Data (250K Trace Files) attributes were assigned to the $100 \mathrm{~K}$-scale DLG hydrography. The Pacific Northwest River Reach data were used because the DLG pieces were already paneled together. For more detailed information, refer to non-PSEA processing steps, Appendix A.

\section{Water Body System}

As part of the Clean Water Act (Section 305 [b]), the U.S. Environmental Protection Agency and the Washington Department of Ecology have delimited a set of water bodies in Washington State. This water body system in the Puget Sound, which includes 69 significant embayments and estuarine areas, was enclosed with artificial closure lines and digitized into a shoreline coverage of the Puget Sound. Each embayment was assigned a label, and the area of the embayment identified by that label was calculated in square miles. A plot of both the digital shoreline and embayments is shown in figure 2 .

Table 2. List of Puget Sound Basin 1:100,000-scale U.S. Geological Survey topographic maps

[With GIS (geographic information system) abbreviation and date of last revision]

\begin{tabular}{|c|c|c|c|c|c|}
\hline Map name & GIS name & Date & Map name & GIS name & Date \\
\hline Bellingham & bell & 1975 & Robertson Mountain & robi & 1979 \\
\hline Cape Flattery & flat & 1981 & Roche Harbor & roch & 1981 \\
\hline Centralia & cent & 1980 & Sauk River & sauk & 1978 \\
\hline Chehalis River & cheh & 1979 & Seattle & seat & 1975 \\
\hline Mount Baker & mbak & 1979 & Shelton & shel & 1979 \\
\hline Mount Olympus & moly & 1979 & Skykomish River & skyk & 1975 \\
\hline Mount Rainier & rain & 1978 & Snoqualmie Pass & snoq & 1978 \\
\hline Port Angeles & pang & 1979 & Tacoma & taco & 1978 \\
\hline Port Townsend & ptow & 1975 & Twisp & twis & 1978 \\
\hline
\end{tabular}


Table 3. Resource name, source agency, and date of data that were collected for the Puget Sound Geographic Information System from sources other than the Puget Sound Environmental Atlas

[NOAA, National Oceanic and Atmospheric Administration; USGS, U.S. Geological Survey; NMD, National Mapping Division; USGS, U.S. Geological Survey; WRD, Water Resources Division of the USGS; WDNR, Washington Department of Natural Resources; WDOE, Washington Department of Ecology: WDOH, Washington Department of Health; WWRIA, Washington Water Resource Inventory Areas; DLGs, Digital Line Graphs]

\begin{tabular}{|c|c|c|c|c|c|c|c|c|}
\hline \multirow[b]{2}{*}{ Resource name } & \multirow[b]{2}{*}{ Data-layer name } & \multicolumn{7}{|c|}{ Agency number and label } \\
\hline & & $\begin{array}{c}1 \\
\text { NOAA } \\
\text { data }\end{array}$ & $\begin{array}{c}2 \\
\text { NOAA } \\
\text { chart }\end{array}$ & $\begin{array}{c}3 \\
\text { USGS } \\
\text { NMD }\end{array}$ & $\begin{array}{l}4 \\
\text { USGS } \\
\text { WRD }\end{array}$ & $\begin{array}{c}5 \\
\text { WDNR }\end{array}$ & $\begin{array}{c}6 \\
\text { WDOE }\end{array}$ & $\begin{array}{c}7 \\
\text { WDOH }\end{array}$ \\
\hline Shoreline ${ }^{1,2}$ & sound & & & $1974-81$ & 1990 & & & \\
\hline Water Body System ' & embayments & & $1989-90$ & & & & 1990 & \\
\hline Hydrography general 1,2 & hy.'gis name' & & & $1974-81$ & 1990 & & & \\
\hline Hydrography network 1,2 & hydro'1-21'.utm & & & $1974-81$ & 1990 & & & \\
\hline Hydrologic Units & ps_huc & & & 1984 & 1990 & & & \\
\hline Puget Sound Basin & ps_basin & & & & 1990 & & & \\
\hline WWRIA & ps_wria & & & & & 1988 & & \\
\hline Political Boundaries & bound & & & $1974-81$ & & & & \\
\hline Public Land Survey & nd_'gis name' & & & $1974-81$ & & & & \\
\hline Geographic Names & wagz_ps & & & $1974-81$ & & & & \\
\hline Shellfish Inventory 1 & doh_shell;sew;rec & & $1987-88$ & $1974-81$ & & & & 1990 \\
\hline Bathymetry data $^{3}$ & bathy & $1935-87$ & & & & & & \\
\hline Grain Size data ${ }^{3}$ & psamp & $1935-87$ & & & & & & \\
\hline
\end{tabular}

I Multiple sources are listed when the data layer was derived from a combination of sources. For example, the respective State agencies responsible for the embayment boundaries and the shellfish inventory data used NOAA nautical charts as base maps. Frequently, data were composited onto NMD DLG shoreline data.

2 Individual 1:100,000 USGS Quadrangle DLGs used; dates are for NMD data (published topographic map).

3 Not described in this report.

\section{Upland Hydrography}

\section{General Hydrography}

The Pacific Northwest River Reach files for the general upland hydrography of Puget Sound were provided in two separate coverages. The first coverage contained centerlines, including the original singlestranded stream reaches, whose width was digitized as a single arc. Wider reaches, such as reservoirs and braided streams, were digitized as a single arc representing a hydrologic centerline connection through these features. The second coverage contained polygons representing lakes and double-banked streams. These two data layers were recombined and edited to produce the general hydrography data layer consisting of a $100 \mathrm{~K}$-scale quadrangle boundary tile structure having a total of 18 tiles that were stored in a UTM Zone 10 projection.

The marine shoreline and centerlines from the Pacific Northwest River Reach data layers were not included in the general hydrography data layer. The original U.S. Geological Survey $100 \mathrm{~K}$-scale DLGs were not used for two reasons: (1) the coverage lacked attributes such as stream name and U.S. Environmental Protection Agency-RF2 codes (Horn, 1986), and (2) edgematching the adjacent quadrangles and paneling the 64 pieces of $100 \mathrm{~K}$-scale DLGs had already been done for the Pacific Northwest River Reach project. The $100 \mathrm{~K}$-scale quadrangle maps were projected to UTM from an Albers Equal Area map projection. A plot of the general hydrography, including the shoreline, is shown in figure 3.

\section{River Reach Network}

In addition to the general hydrography layer, the PSGIS project also includes data transport layers called River Reach Networks for which GIS routing processes can be used and in which the double-banked streams and reservoirs have been centerlined. These layers were obtained from the Pacific Northwest River Reach study in April 1990 and were tiled by U.S. Geological Survey hydrologic unit code (HUC). The Puget Sound shoreline was deleted from each layer and the tile renamed to correspond to its respective HUC. The tile was projected to UTM from an Albers Equal Area map projection. 




Base map from U.S. Geological Survey

1:100,000 Digital Line Graphs, 1989a.

Figure 2. Puget Sound shoreline and embayments from digital data. 


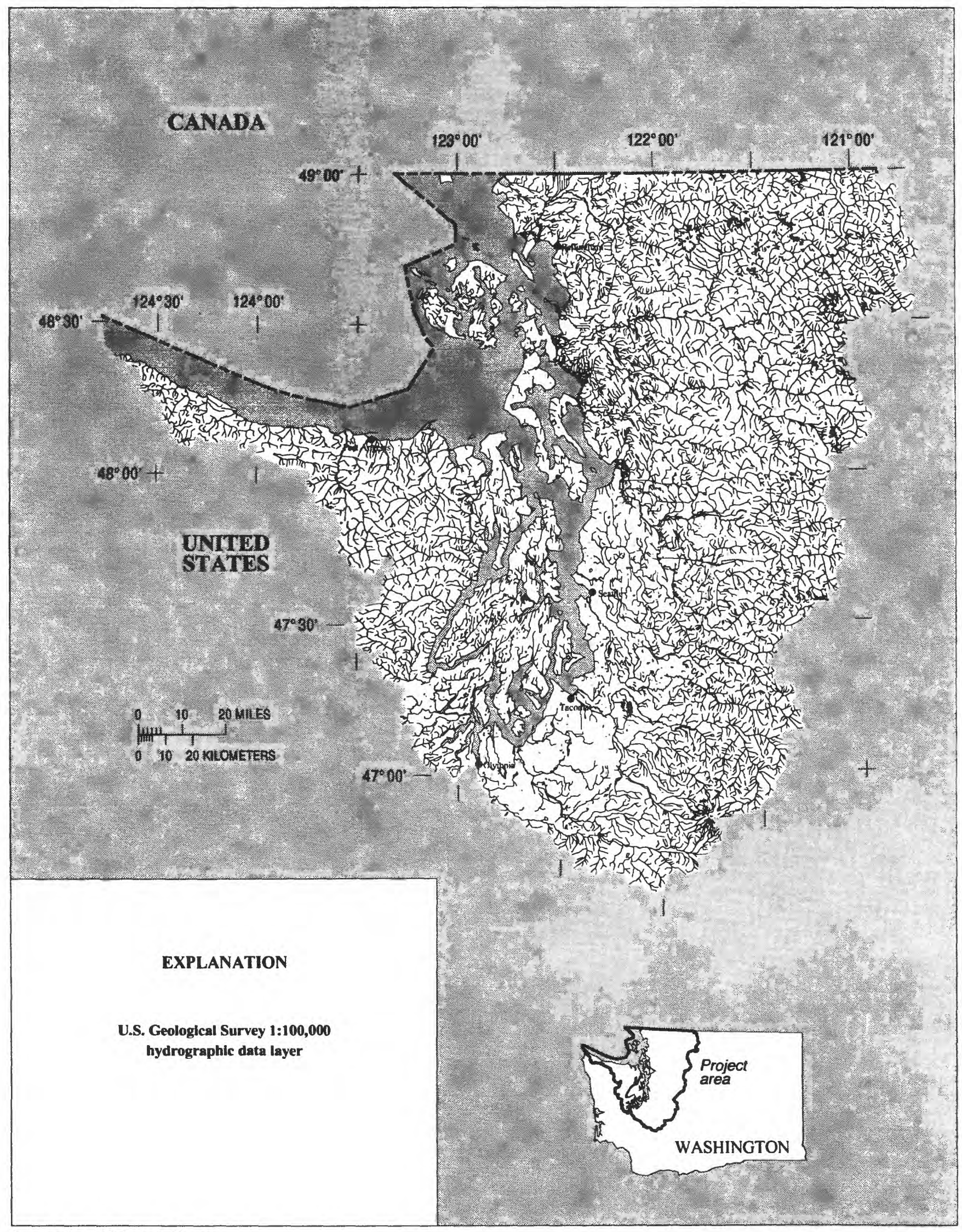

Base map from U.S. Geological Survey 1:100,000 Digital Line Graphs, 1989a.

Figure 3. General hydrography data layer with the Puget Sound shoreline. 


\section{Watershed Boundaries}

\section{Puget Sound Area}

The PSGIS data layer of the Puget Sound area (HUC 17110000, which includes 21 subbasins-HUCs 17110001 through 17110021 [fig. 4]), was created as a reference layer for other data layers, such as the hydrography and Washington Water Resource Inventory Areas. The watershed boundary coverage for HUC 17110000 was obtained from the U.S. Geological Survey National Mapping Division as a generalized 1:2.5-million- scale coverage that was redelineated to capture headwater and lower reaches at $100 \mathrm{~K}$ scale as part of the Pacific Northwest River Reach project. In order to create the Puget Sound Area data layer, all of the subbasin HUC boundaries under regional boundary 17 and subregional boundary 11 were eliminated. The resulting data layer consists of one outer boundary (HUC 17110000); the inner boundaries (accounting [00] and cataloging [01-21] units) have been removed.

\section{Washington Water Resource Inventory Areas}

The Washington Department of Ecology has delineated watershed areas, called Washington Water Resource Inventory Areas, that are similar to the U.S. Geological Survey HUCs (Washington Department of Ecology, 1986). The boundaries of the Washington Water Resource Inventory Areas differ from U.S. Geological Survey HUC boundaries by the additional subdivision of some subbasins, particularly subbasins at the Canadian border. In addition, only a few of the Washington Water Resource Inventory Areas follow the legal description of an area, which may not be entirely based on hydrology, as are the U.S. Geological Survey HUC boundaries. These Washington Water Resource Inventory Areas are the basis for the Washington Department of Ecology's water-management policies and are provided as an index and reference layer for the PSGIS. The digitized Washington Water Resource Inventory Areas were obtained from the Washington Department of Natural Resources, Division of Aquatic Resources, and the resulting data layer was projected from a Washington State Plane coordinate (south zone) to UTM Zone 10 projection. Washington Water Resource Inventory Areas that are not within the Puget Sound area (HUC 17110000) were removed from the original statewide data layer received from the Washington Department of Natural Resources. A map of the Puget Sound Washington Water Resource Inventory Areas is shown in figure 5.

\section{Political Boundaries and}

\section{U.S. Public Land Survey System}

The data layers containing political unit boundaries and U.S. Public Land Survey System features were obtained from the U.S. Geological Survey National Mapping Division 100K-scale DLGs. The boundary DLG data layer includes Federal and Tribal lands information and State and county Federal Information Processing Standard (FIPS) codes. The coverage of counties in the Puget Sound area was created by selecting the county FIPS code contained in the major and minor attributes and clipping with the Puget Sound boundary (U.S. Geological Survey, 1989a). DLGs of the U.S. Public Land Survey System contain township and range section lines, benchmark monument locations, surveyed section corners, and other surveyed data (refer to Appendix A for additional processing steps).

\section{Geographic Names}

The Geographic Names data layer, obtained from the Washington State Department of Fish and Wildlife, is a point data layer developed from the U.S. Geological Survey, National Mapping Division, Geographic Names Information System file for the State of Washington. The data layer was converted from the Washington State Plane coordinate system (south zone) to UTM Zone 10 projection. The point data layer was clipped to match the extent of the Puget Sound area and includes 7,941 point locations for cities, towns, landmarks, and geographic and hydrologic features.

\section{Shellfish Inventory}

\section{Shellfish Growing Areas}

The location of commercial growing areas, obtained from the 1990 Shellfish Inventory produced by the Washington Department of Health Shellfish Programs (Washington Department of Health, 1990), was digitized. The official classification status for harvesting and growing of commercial shellfish in the area of the Puget Sound is identified in the 1990 Shellfish Inventory. Each polygon or growing area was assigned an attribute for classification status. This classification status is divided into five categories: Commercial Area, Approved, Conditionally Approved, Restricted, and Prohibited. Several status areas overlapped and were assigned an attribute with a combined double name, such as Commercialprohibited. A map of the digitized 1990 Shellfish Inventory is shown in figure 6. Further processing procedures are detailed in Appendix A. 




Base map from U.S. Geological Survey

1:100,000 Digital Line Graphs, 1989a.

Figure 4. U.S. Geological Survey hydrologic unit boundaries for the Puget Sound area. 


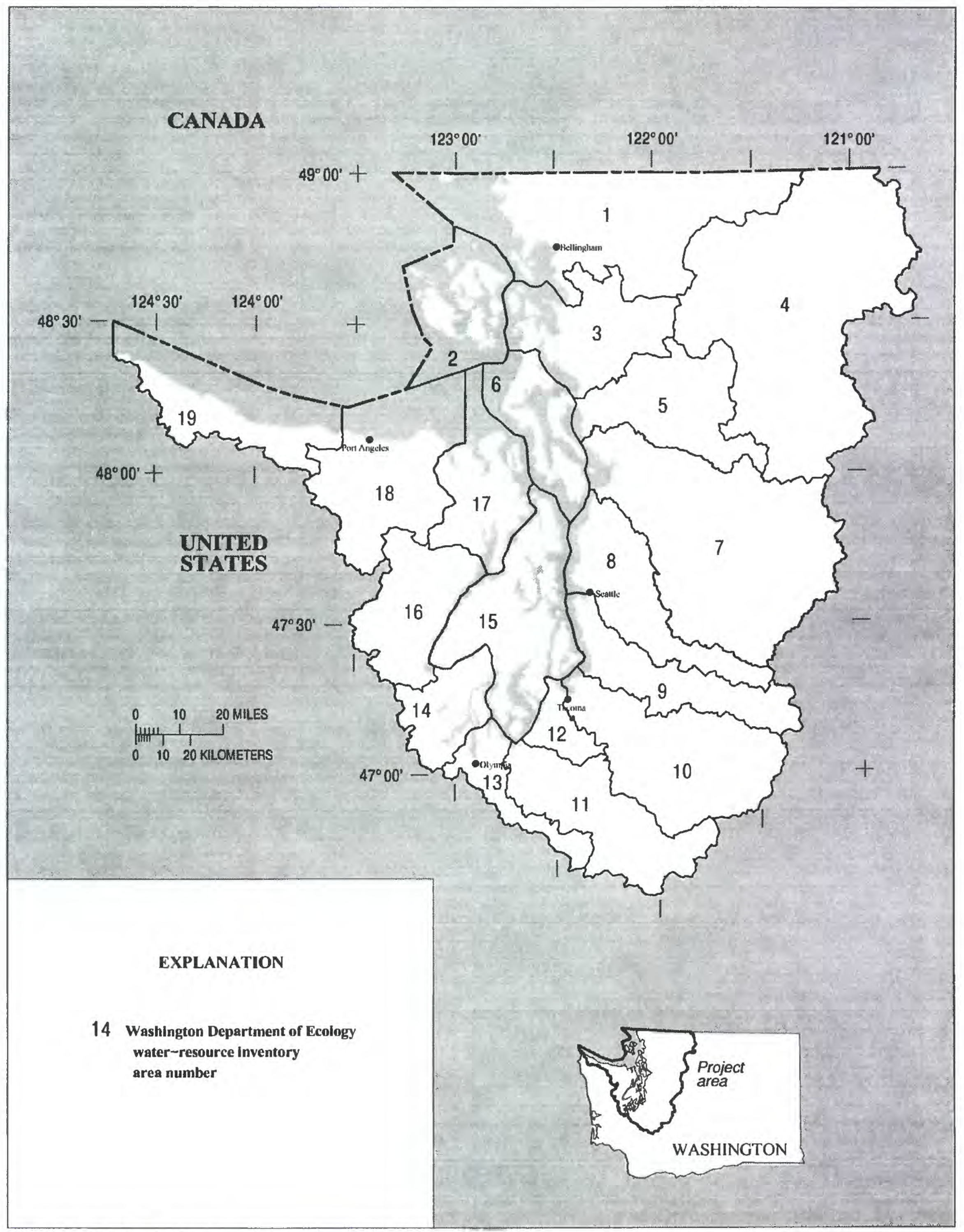

Base map Irom U.S. Geological Survey

1:100,000 Digital Line Graphs, 1989a.

Figure 5. Washington Department of Ecology water-resource inventory areas for the Puget Sound Basin. 


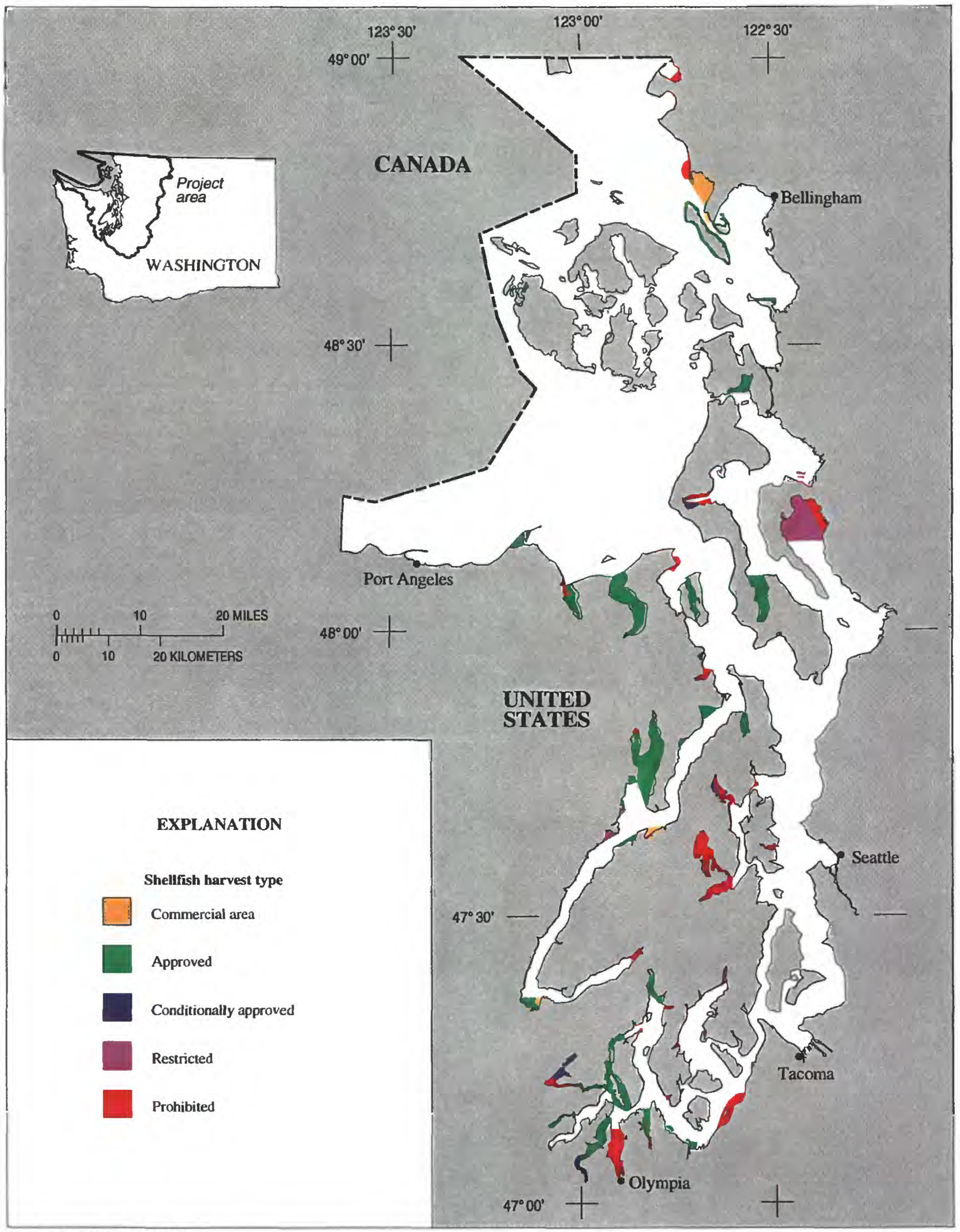

Base map from U.S. Geological Survey

1:100,000 Digital Line Graphs, 1989a.

Figure 6. Shellfish growing areas from the Washington Department of Health 1990 Shellfish Inventory. 


\section{Recreational Shellfish Beaches}

The location of recreational shellfish beaches, shown in the 1990 Shellfish Inventory (Washington Department of Health, 1990), was digitized as a point coverage. The 1990 Shellfish Inventory depicts recreational shellfish beaches in State, Washington Department of Natural Resources, and county parks. Symbols and numbers denote the agency responsible for maintaining the beach or park and the beach or park name. Attributes were included to indicate this information (see Appendix A for more information).

\section{Sewage-Treatment Outfalls}

The location of municipal sewage-treatment outfalls, shown in the 1990 Shellfish Inventory (Washington Department of Health, 1990), also was digitized as a point coverage. Municipal sewage-treatment outfall locations are represented by a triangular symbol. A point coverage was created by digitizing the approximate center point of the triangle. Because the 1990 Shellfish Inventory maps did not have precise coordinates for the outfalls, the triangles and their centers should be considered as cartographic representations of real-world data; exact latitude/longitude coordinates for the points digitized were not known and were approximated. An attribute for the name of the sewagetreatment outfall was included. The recreational shellfish beaches and sewage-treatment outfalls are shown in figure 7.

\section{Processing Procedures}

Processing procedures for non-PSEA data varied widely. An effort was made during the pilot phase to identify existing sources of digital data, such as DLG files. Whenever possible, the data were acquired from an agency that already had the information in ARC/INFO format. When existing digital data were not available, the resource-layer maps were digitized.

Quality assurance for resolution and registration errors was performed after processing the data. National Map Accuracy Standards (U.S. Geological Survey, $1989 \mathrm{~b}$ ), were used in the quality assurance process. As an example, for $100 \mathrm{~K}$-scale data layers, the map precision in ground units is $\mathbf{5 0 . 9}$ meters. This quality inspection varied for different data themes and sources.

For instance, because the 1990 Shellfish Inventory areas were transferred manually to a base of higher precision and then digitized, the shape, location, and attributes of the data were rigorously checked. However, in the case of the U.S. Public Land Survey System data, in which DLGs from the National Mapping Division of the U.S. Geological Survey were imported to ARC/INFO format, only the edgematching of adjacent panels underwent quality checks (Nebert, 1989).

\section{Digital Line Graph Files}

DLGs from the National Mapping Division of the U.S. Geological Survey, the initial source for the shoreline and upland hydrography data layers, also were converted to ARC/INFO format for the Puget Sound boundary and the U.S. Public Land Survey System data layers. The $100 \mathrm{~K}$-scale DLG data are ordered by quadrangle sheet $(30 \times 60$-minute series $)$ and divided into from 4 to 32 sections, depending on the data type, for each east and west half of the quadrangle sheet. The DLGs were processed using the ARC/TNFO command: DLGARC ${ }^{\prime}$. All of the data (line, area, label, node) contained in the DLGs were imported into ARC/INFO. For the U.S. Public Land Survey System data, this meant that some quadrangle sheets had two final data layers. One data layer contained line, polygon, and label data; a second data layer contained point data, such as benchmarks and surveyed monuments.

\section{Existing Digital-Spatial Data}

Processing required for data layers formatted in ARC/INFO ranged from basic projection of a data layer into the PSGIS-UTM-coordinate system to extensive manual editing and manipulation of a data layer to achieve the desired resolution and naming convention. The hydrography, including the shoreline, existed in ARC/INFO format as Pacific Northwest River Reach data sets. The Pacific Northwest River Reach product consists of a topologically linked, network data layer with centerlines replacing double-banked streams and water bodies, and a polygon, banks data layer of these double-banked streams and water bodies. From these two products, the PSGIS derived three data sets: a Puget Sound shoreline, a cartographic-general hydrography, and a linked-network hydrography.

${ }^{1}$ All ARC/INFO commands in this report are capitalized and use software version 5.0.1; refer to Environmental Systems Research Institute, Inc., 1989, for a complete explanation. 


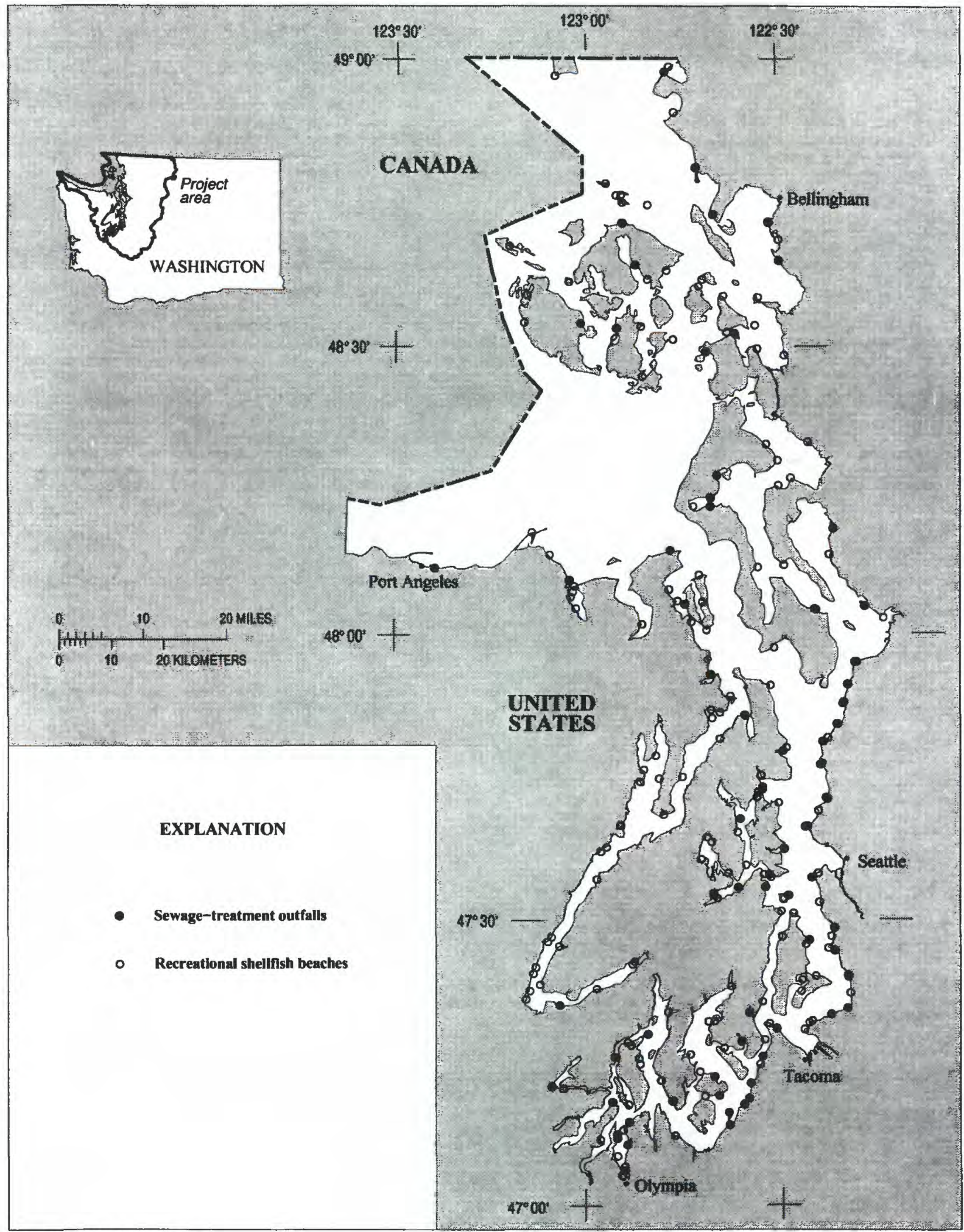

Base map from U.S. Geological Survey 1:100,000 Digital Line Graphs, 1989a.

Figure 7. Sewage-treatment outfalls and recreational shellfish beaches from the Washington Department of Health 1990 Shellfish Inventory. 


\section{Shorelline Data Layer}

To create the Puget Sound shoreline data layer, arcs were extracted from the banks data layer. For Puget Sound shoreline pieces missing from the banks data layer coverage, the network data layers of each subbasin (HUCs 17110001 through 171 10021) in the Puget Sound area were used. Where double-banked streams entered the Puget Sound, an arc was added to close off the mouth of the stream. These arcs were given a COVER-ID equal to 9999 as a flag for later reference. The closures were added to create a topologically correct coverage where the water body of Puget Sound is contained in a single polygon. These closures were not field located at the beginning of an estuary or determined by head-of-tide zones but were hand digitized by visual alignment with the existing shoreline. These closures may require modification for certain applications. A section of the San Juan Island data set, which was missing from the Pacific Northwest River Reach data set, also was digitized.

\section{Upland Hydrography Data Layer}

The general upland hydrography cartographic data layer was created by merging the network and banks data layers together and eliminating the centerlines. This process is detailed in Appendix A. The Puget Sound subbasins (HUCs 17110001 through 17110021 ) were merged at the boundaries of the $100 \mathrm{~K}$ scale quadrangles. The hydrography was clipped into the tiles chosen by the multi-agency PSGIS design work group.

\section{Network Data Layer}

The linked-network hydrography is a final product of the Pacific Northwest River Reach project. This coverage is a topological network with an extended database; routing up or down from a given reach is possible either with the spatial network or within the tabular database. There are items within this extended database to relate the topological network to the $250 \mathrm{~K}$ scale U.S. Environmental Protection Agency River Reach files (Horn, 1986), the U.S. Environmental Protection Agency STORET Data Base, and the Northwest Environmental Data Base (Bonneville Power Administration, 1990). A provisional network data layer was acquired for the PSGIS in March of 1990. Since that time, the final product has been modified to remove the pseudo nodes that broke the stream network at $100 \mathrm{~K}$-scale quadrangle, 24K-scale quadrangle, and county boundary lines. However, because the Puget
Sound Water Quality Authority wanted to retain these pseudo-node features, the earlier version of the PSGIS network data layer was used instead of the modified version (Fisher, 1996).

\section{Data Digitized for the Puget Sound Geographic Information System}

Data that were digitized included the Washington Department of Ecology Water Body System delineation and the Washington Department of Health 1990 Shellfish Inventory.

\section{Water Body System}

The embayment delineation and numbering system was depicted on six National Oceanic and Atmospheric Administration nautical chart base maps. Five of these base maps were in unique Mercator projections at a scale of $1: 80,000$ and one was in a Polyconic projection at $1: 40,000$. The Puget Sound shoreline data layer was used as a template and was transformed into the same projection as each nautical chart base map. The shoreline template was overlaid on the shoreline of each nautical chart base map, and the delimiting embayment boundaries were digitized and joined to a copy of the shoreline data layer. Attributes were added to indicate the Washington Department of Ecology embayment number and area in square miles.

\section{Shellifish Inventory}

The 1990 Shellfish Inventory maps from the Washington Department of Health were created by delineating the status areas on four National Oceanic and Atmospheric Administration nautical chart base maps in Mercator or Polyconic projection, which were later reproduced by commercial photocopy. This photocopy process produced maps of poor quality that could not be registered within accepted tolerances (root-mean-square [RMS] errors must be less than 0.003 ) and, therefore, the photocopied maps could not be used as a source for digitizing. In addition, information necessary to the accurate replication of data, such as scale, projection, and date of the base map, were blanked out from the National Oceanic and Atmospheric Administration nautical chart base map by the 1990 Shellfish Inventory map legend and by other text.

The photographic negatives used to create the photocopies were acquired. Although the photographic negatives are a stable base, the 1990 Shellfish Inventory status areas had been identified using zip-atone on mylar. Because the patterns were difficult to 
distinguish and there were 16 separates, the photographic negatives were not digitized. Instead, the four maps were hand traced onto a plot of the shoreline data layer projected to Mercator or Polyconic. Using this plot of the shoreline data layer as a template, the handtraced status areas were digitized by overlaying the 1990 Shellfish Inventory shoreline onto the shoreline data layer. The final product joined a copy of the shoreline data layer with the hand-traced status areas and was projected back to UTM. With this method, no additional resolution, registration, or projection errors would be introduced because all layers would contain identical shorelines.

The 1990 Shellfish Inventory contains additional information about recreational shellfish beaches and sewage-treatment outfalls. This information also was digitized and placed into separate ARC/INFO data layers. Refer to information about DOHREC and DOHSEWAGE attributes in Appendix A.

\section{PUGET SOUND ENVIRONMENTAL ATLAS DATA LAYERS}

\section{Data Sources}

The PSEA was originally compiled by EvansHamilton, Inc., for the Puget Sound Water Quality Authority. Digital cartographic files were created by D.R. Systems of Vancouver, British Columbia, Canada (Evans-Hamilton, Inc., and D.R. Systems, Inc., 1987). These digital files were archived by the U.S. Army Corps of Engineers in Seattle, Washington. The archived files are Intergraph design files in VAX backup format and were written to magnetic tape as "Base" and "Extra" file data. Base and Extra are project-specific nomenclature for the design files. Base refers to the first items included on the base map and Extra to items added onto the base (Environmental Systems Research Institute, Inc., 1988). The Bonneville Power Administration, which has both Intergraph and ARC/INFO capability, converted the design file format to AutoCAD Drawing Interchange Format (DXF). The AutoCAD DXF could then be imported to ARC/INFO. The conversion to AutoCAD was completed by Bonneville Power Administration for all 12 regions of the PSEA. Two DXF files were created from 2 Intergraph files for each of the 12 PSEA regions: a DXF Base file contained 90 percent of the desired PSGIS data; a DXF Extra file contained the kelp and eelgrass data, as well as other information.

\section{Layer Descriptions}

Data topics from the PSEA were composited in logical groups to form PSGIS data layers that included seabirds, habitat type, marine mammals and fish, as well as shellfish resources and bed type. Because location of many of the resources are coincident (clams and oysters can occupy the same beds), many of the data fields created in the PSGIS are simple presence/absence flags, in which the particular resource attribute is given a value equal to 1 if present and 0 if not present. The simplicity of this data structure allows the coincident location of resources to be described in a single, composited data layer. In addition, the original, uncomposited species and resources data in each of the data layers are provided as separate coverages. The individual coverages that constitute the composited data layer are listed in table 4. The final data-set products and attribute-field definitions are documented in Appendix B.

\section{Seabird Nesting Areas}

The PSEA contains information on the location of seabird nesting sites in the Puget Sound area. Seabird species represented in this data set include glaucouswinged gull, double-crested cormorant, pelagic cormorant, pigeon guillemot, tufted puffin, rhinoceros auklet, black oystercatcher, and arctic tern. The seabird data layer in the PSGIS is a reproduction, presented in digital form, of PSEA information and associated database files. The digitized locations of many of the seabird nesting areas, by species, are shown in figure 8 .

\section{Nearshore Habitat}

Habitat data compiled in the PSEA includes an "Eelgrass, Kelp beds" map sheet for each of the 12 PSEA regions. The PSEA also contains information on Habitat Management Areas, National Estuarine Sanctuaries, Nature Preserves, and National Wildlife Refuges. Only the eelgrass and kelp bed data were converted and composited into the nearshore-habitat data layer. The polygon label points of the digitized kelp and eelgrass beds throughout the Puget Sound area are shown in figure 9. Because of their small size and similarity to the shoreline data layer, polygons of the eelgrass and kelp bed areas were not plotted. Instead, to increase the visibility of the kelp and eelgrass bed areas, symbols were used for the label points. 
Table 4. Data layers, resource layers, and definitions of the Puget Sound Environmental Atlas

[ID\#, data-layer identification number, GIS, geographic information system]

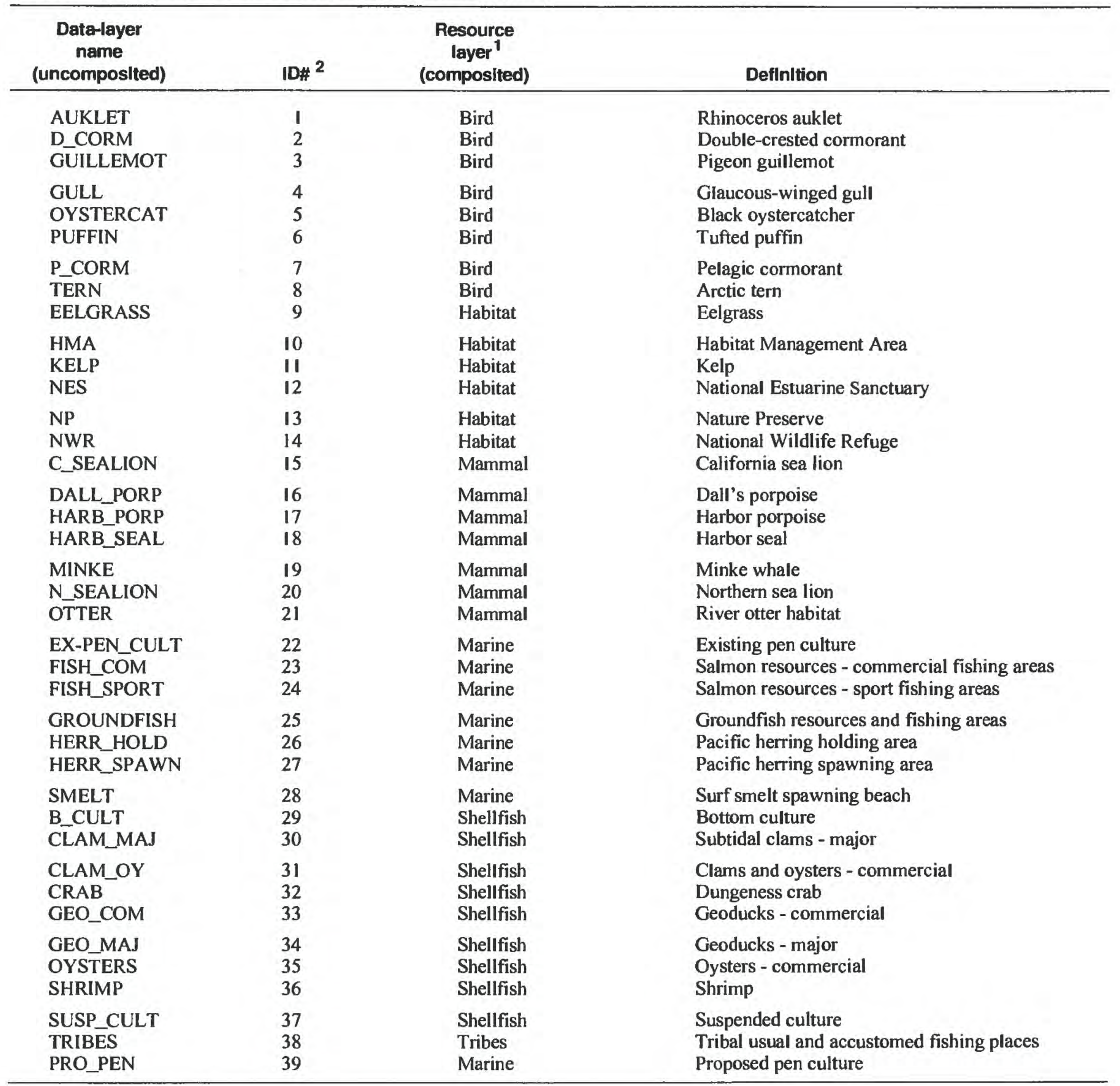

1 These resource layer names are the digital-data names used in the GIS processing and correspond to the following composite of data-layers in text.

\begin{tabular}{ll} 
Digital name & \multicolumn{1}{c}{ Heading in text } \\
\hline Bird & Seabird nesting areas \\
Habitat & Nearshore habitat \\
Mammal & Marine mammal \\
Marine & Marine fish \\
Shellfish & Shellfish \\
Tribes & Tribal areas
\end{tabular}

2 The ID\#'s are the coverage-ID's in the INFO database assigned to each data layer in the Puget Sound Geographic Information System. Cover-ID's are the integer numbera in the feature attribute table that are used to identify arcs, polygons, points, and nodes. 


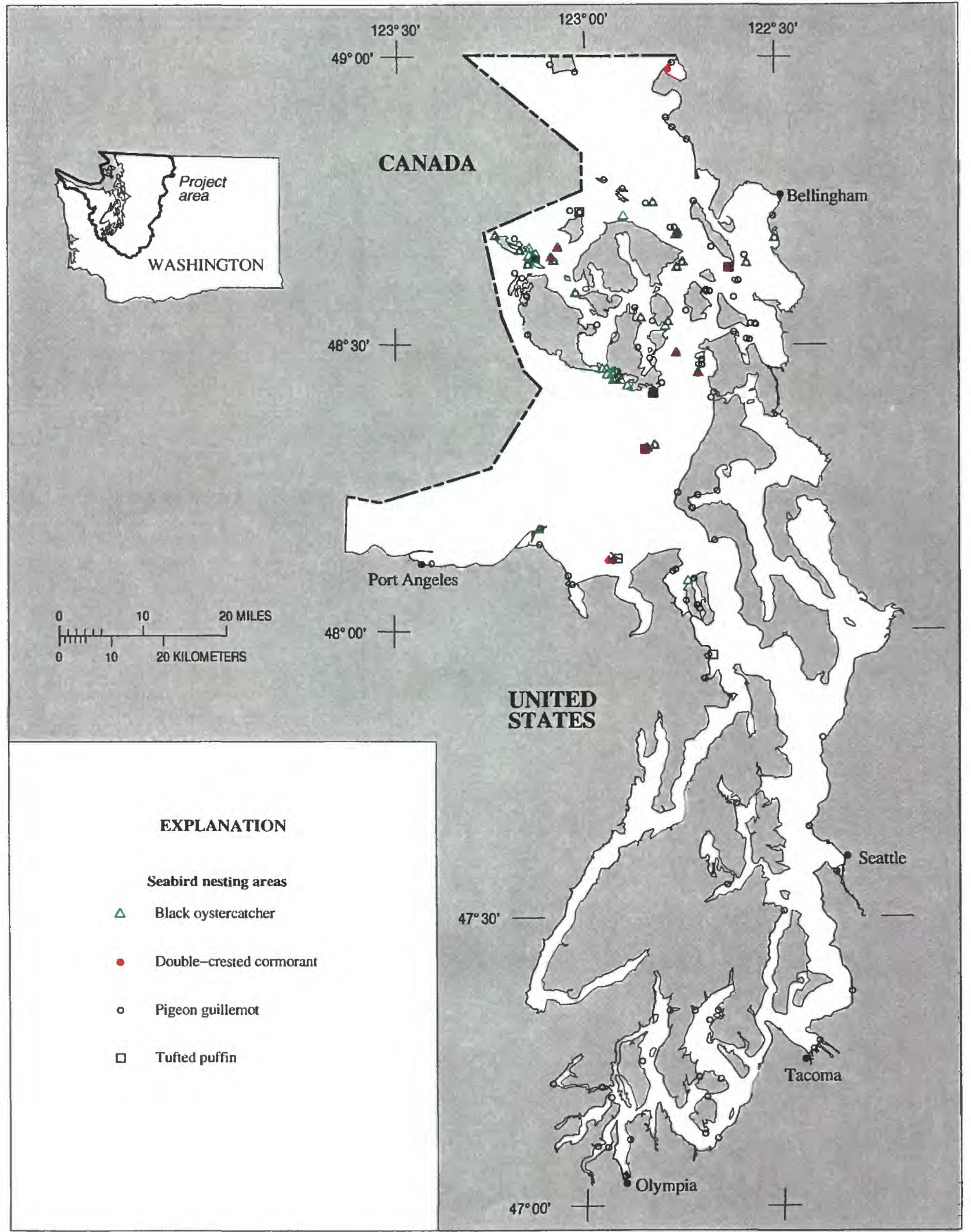

Base map from U.S. Geological Survey 1:100,000 Digital Line Graphs, 1989a.

Figure 8. Digitized locations of seabird nesting areas for selected species. 


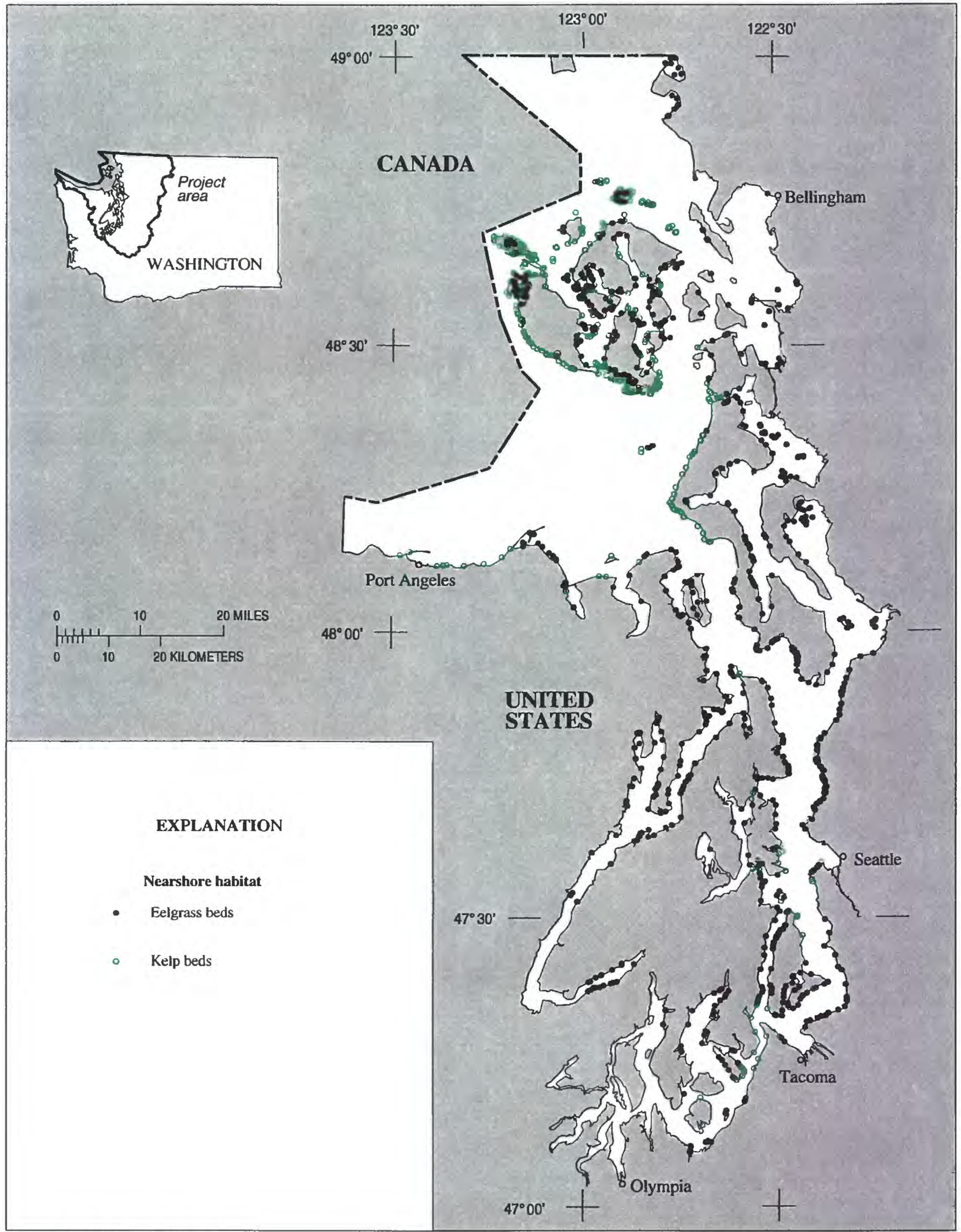

Base map Irom U.S. Geological Survey

1:100,000 Digital Line Graphs, 1989a.

Figure 9. Digitized locations of kelp and eelgrass beds larger than one acre. 


\section{Marine Mammal}

Data on marine mammals, compiled in the PSEA and converted to PSGIS, consists of haul-out locations and confirmed sightings. Species at haul-out sites include harbor seal, northern sea lion, and California sea lion. Species sighted included Dall's porpoise, harbor porpoise, and minke whales. Habitat also was delineated for the river otter. Some of the data portrayed in the PSEA for Regions 4, 5, and 6 were not available in the digital data files and some were digitized from original PSEA mylars. A plot of the digitized locations for selected marine mammals, except for minke whales, is illustrated in figure 10 .

\section{Marine Fish}

The marine fish data layer in PSGIS consists of information from PSEA map sheets on Aquaculture, Salmon Resources, and Marine Fish Resources. Species and location information in the marine fish data layer includes existing and proposed pen aquacultures; salmon resources commercial and sport fishing areas; marine fish resources - groundfish resource and fishing areas, Pacific herring holding and spawning areas, and surf smelt spawning beaches. The digitized salmon and groundfish resources are shown in figure 11 and the Pacific herring areas in figure 12.

\section{Tribal Areas}

Separate information from the PSEA map sheets was compiled for Tribal names and areas. Information on Tribal areas was contained on the same map sheet as the Salmon Resources and was listed as Usual and Accustomed Fishing Places; the specific Tribal designation also was included. Like the water body data layer, the lines delimiting Tribal areas were digitized and added to a copy of the shoreline data layer. Attributes for a Tribal name were assigned to respective Tribal areas, and a data layer for named Tribes was created.

\section{Shellfish}

The shellfish layer consists of data from PSEA map sheets of Shellfish Resources and Aquaculture/ Shellfish Bed Certification Status. Attribute items included the species present (clams, oysters, shrimp, Dungeness crab, and geoducks) and area-use type, such as commercial or potential commercial. Aquaculture information includes data on suspended and bottom cultures.
Because of the many species in the Shellfish Resources maps, there are overlaps between data layers. For instance, the crab data layer contains numerous combinations of the other data layers at certain locations. When each species layer is plotted, a mottled pattern of overlapping results making it difficult to discern the actual area in which a species may be present. For this reason, crab and shrimp areas were depicted separately (figure 13). The bottomdwelling species — clams, geoducks, and oysterswere grouped with bottom and suspended cultures.

\section{Processing Procedures}

The processing of the PSEA data layers consisted of three steps. First, the Intergraph files were converted to ARC/INFO format. Second, the data layers were correctly registered to a world-coordinate system with a low RMS error. Third, each resource type was extracted as a unique data layer.

\section{Drawing Interchange Format File Conversion}

The DXF file is in a compatible exchange format between Intergraph and ARC/INFO software. The Intergraph design files contain 35 separate levels of graphic data which directly correspond to AutoCAD DXF layers. The DXF format is an ASCII file and contains information about line types, annotation, color, as well as the coordinate values for the line data. The DXF files are large. As an example, the primary file (BASE6.EHI) for PSEA Region 6 was 6.8 megabytes. Shorelines were digitized in stream mode, which increased the number of vertices per arc (line) and added to the size of the DXF file. These unneeded vertices were deleted after the DXF file was converted to an ARC/INFO data layer.

Each DXF file was converted to a composite $\mathrm{ARC} / \mathrm{INFO}$ data layer with the ARC command DXFARC (\$REST ALL options). It was determined during the pilot phase of the project that it was easier to transform all of the data at a single time to a worldcoordinate system during the registration process rather than to transform each layer separately. Topology was then constructed using the BUILD command with the LINE option. When the layers were converted, the attributes from DXFARC were contained in an INFO “.ACODE" file (Environmental Systems Research Institute, Inc., 1989). The ACODE file was merged with the coverage Arc Attribute Table (.AAT) to associate the attributes to their corresponding arcs. 


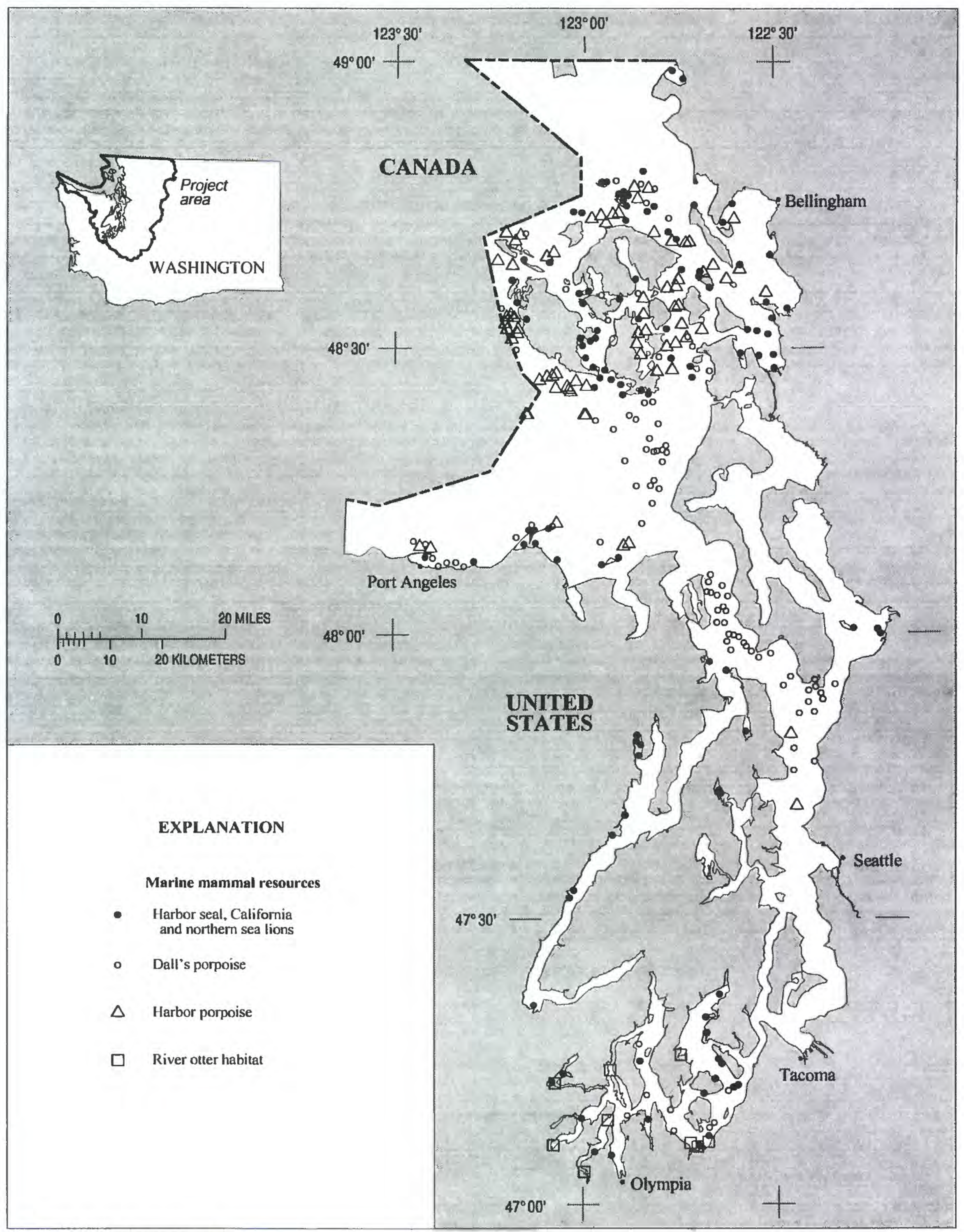

Base map Irom U.S. Geological Survey

1:100,000 Digital Line Graphs, 1989a.

Figure 10. Marine mammal digital points for selected species. 


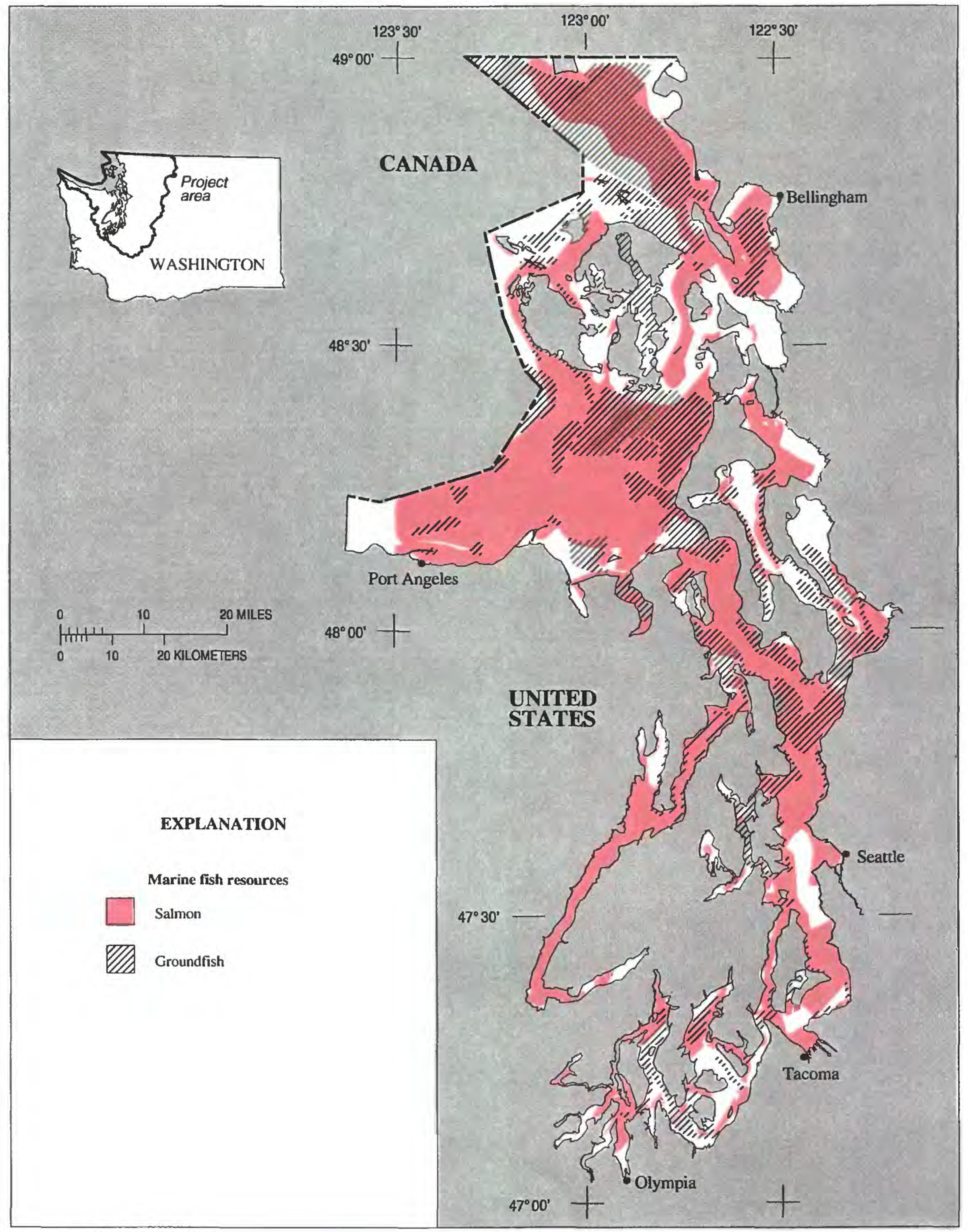

Base map from U.S. Geological Survey

1:100,000 Digital Line Graphs. 1989a.

Figure 11. Salmon and groundfish resources. 


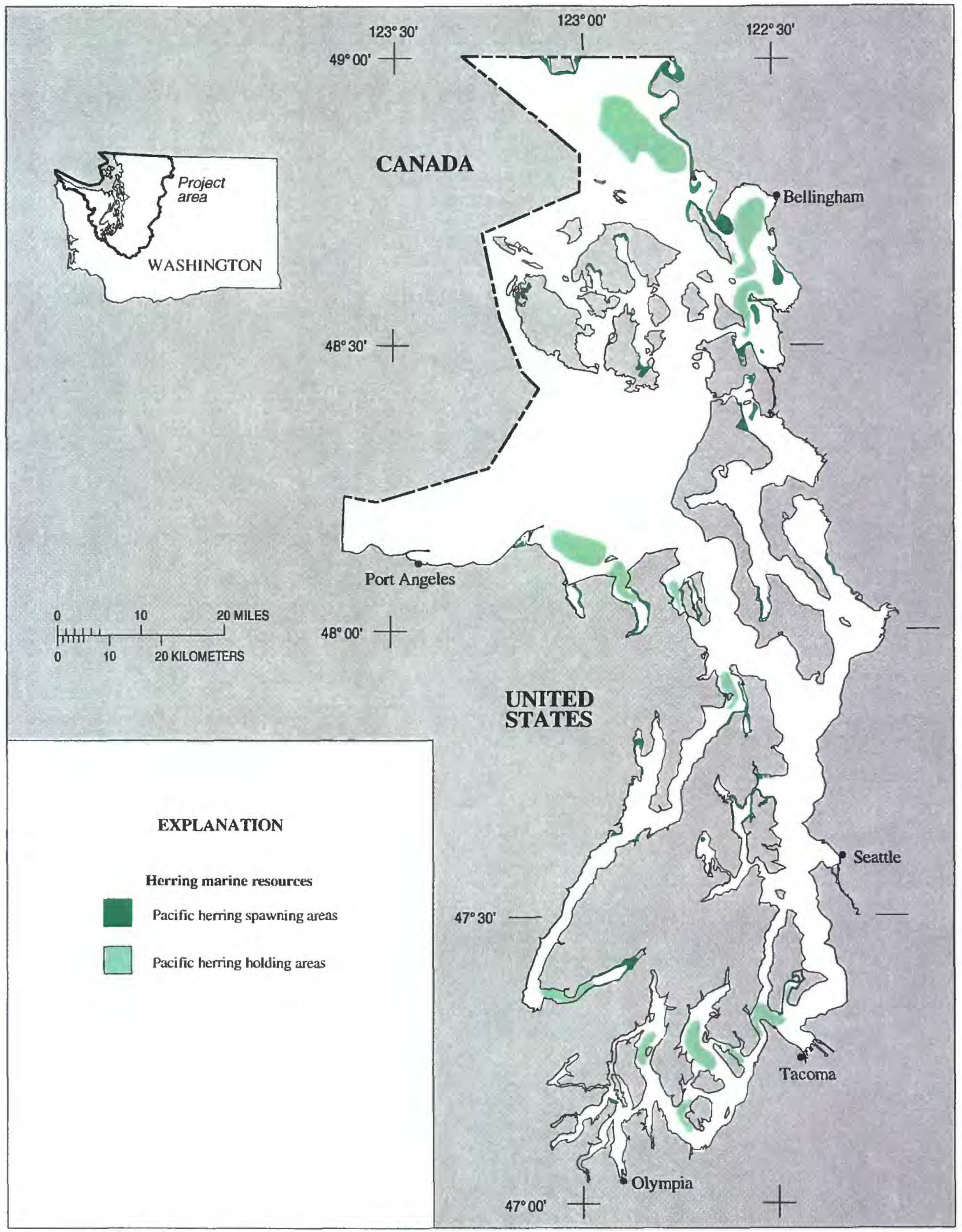

Base map trom U.S. Geological Survey

1:100,000 Digital Line Graphs, 1989a.

Figure 12. Pacific herring resources. 


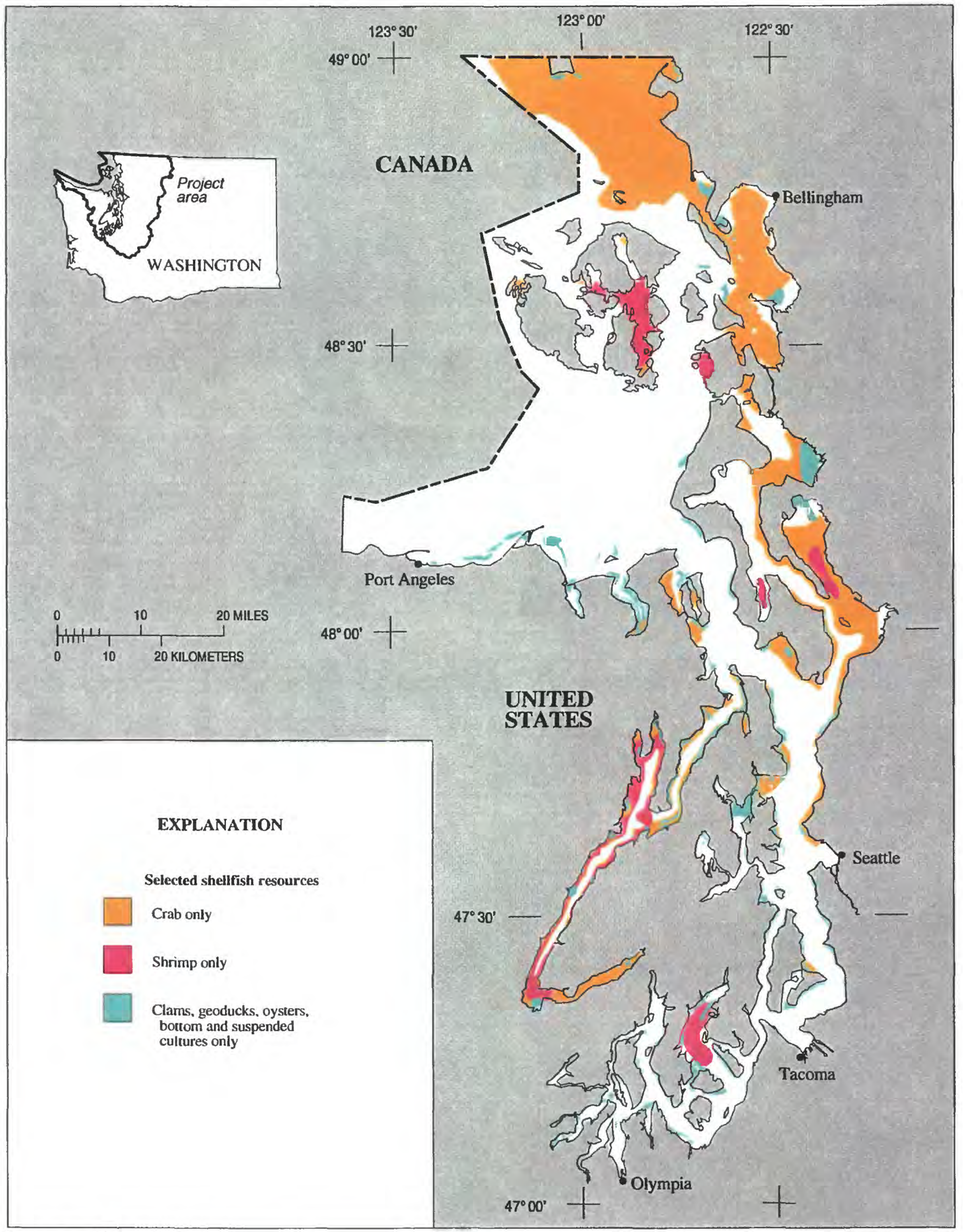

Base map Irom U.S. Geological Survey 1:100,000 Digital Line Graphs, 1989a.

Figure 13. Selected shellfish resources. 
The JOINITEM command was used to merge data fields. The data layers were now ready to be extracted into separate resource data layers using the ARC RESELECT command.

\section{Registration of Data Layers}

The Intergraph design files and subsequent DXF files were not in a known, world-coordinate system. The native coordinate system for the Intergraph design files should use millimeter coordinates in a Polyconic projection. Thus, if the data were plotted at a $24 \mathrm{~K}$ scale, they would overlay a U.S. Geological Survey $24 \mathrm{~K}$-scale quadrangle sheet. The DXF Base and DXF Extra files received by the U.S. Geological Survey used at least three different origin locations and were not always in millimeter coordinates. Because the coordinates were not always the same, the DXF Base and DXF Extra files for each PSEA region did not always precisely overlay each other.

\section{Registration Coordinates}

A set of latitude/longitude grid tics were contained in layer 58 of the DXF Base files. These grid tics were used as geographic controls in the transformation process to register the DXF Base and DXF Extra files. This DXF layer was extracted from the composite ARC/NFO data layer using the ARC RESELECT command. The layer consisted of short lines around the edges of a PSEA region that indicated latitude/longitude line locations. Tics were created at the intersection of these lines but were not attributed. Lines were added to connect these tics and to create a latitude/longitude grid in the native-coordinate system. The intersections of the latitude/longitude grid became the control points for the transformation into a worldcoordinate system.

The latitude/longitude grid was extracted to create a separate data layer, and the ARC NODEPOINT command was used to create points at the latitude/longitude intersections. The transformation process requires that each geographic control point be uniquely identified. The INFO internal ID values were used as unique identifiers, instead of renumbering manually. Each PSEA region had from 21 to 55 control points, depending on the size of the region. The ID values for the point data layers were modified to uniquely identify each point in a region and each point in all the combined regions.
The formula used in the calculation was (in INFO syntax using PSEA Region 12 as an example):

CALC B12_DXFTIC-ID $=1200+$ B12_DXFTIC-ID

This method was used to create a uniquely numbered set of points for the extent of the PSEA area. The points were converted to ARC/INFO tics with the POINT-TIC.AML (S.W. McKillop, U.S. Geological Survey, written commun., 1990). The four arbitrary tics created with the ARC command DXFARC were deleted with the ARC DELETETIC command and the new latitude/longitude tics were substituted into each data layer.

\section{Control Coordinates}

The next step was the creation of a matching geographic-control data layer, in a world-coordinate system. To create this data set, the latitude/longitude for each of the PSEA tic-intersection points was entered into a file as units of degrees, minutes, and seconds. The file coordinates were converted to decimal-degree coordinates with the ARC/NNFO PROJECT command. ID numbers matching the corresponding coordinates in the DXF data layers were given to the new data set and a point data layer was created with the ARC/INFO GENERATE command. ARC/INFO tics were created from the points in each PSEA region with the POINTTIC.AML. All of the tics were then appended into one data layer covering the entire area into a tic coverage called RALL_TIC. These tic IDs and the latitude/longitude coordinates in degrees, minutes, and seconds are listed in Appendix C.

The DXF files are not in a known projection system but when plotted will overlay the U.S. Geological Survey 7-1/2-minute (24K-scale) quadrangle sheets (Environmental Systems Research Institute, Inc., 1988). A Lambert Conformal Conic or Polyconic projection is used for the $24 \mathrm{~K}$-scale quadrangles in the study area, yet each has its own unique projection parameters. A Lambert Conformal Conic projection that covers the same area as the PSEA regions would not have exactly the same parameters as each $24 \mathrm{~K}$-scale quadrangle sheet, but the differences should be small (Snyder, 1987). The State Plane coordinate system also can be in Lambert Conformal Conic. For States such as Washington that have a predominant east-west expanse, Lambert Conformal Conic has the advantage of using only one set of projection parameters; such was the case for the entire Puget Sound area of Washington (Snyder, 1987). 
Ideally, an accurate transformation to a worldcoordinate system would be made with the same projection as the original base map from PSEA. In this case, the DXF coverages were transformed into either a Lambert Conformal Conic or Polyconic projection. Paper copies of these world coordinate, control data layers were generated in Lambert Conformal Conic, State Plane Zone 5626, and UTM and were named RALL_TIC.LAM, RALL_TIC.SP, and RALL_TIC .UTM, respectively. The three projections were used in the early transformation stages to determine the most accurate and the easiest method of registering the DXF coverages.

\section{Root-Mean-Square Error}

There exists inherent error in all transformations of digital data. RMS values are used to quantify this error by performing a mathematical operation on the original and the transformed data. Regions 5 and 6 of the PSEA were used to test the transformation process. The desired end projection was UTM, the projection for the PSGIS and DLG data. The DXF coverages were converted to UTM coordinates by three methods: transformation to Lambert Conformal Conic coordinates and projection to UTM coordinates, transformation to State Plane coordinates and projection to UTM coordinates, and transformation directly into UTM. The RMS error was compared for all three methods. The mathematical formula used to compute the RMS errors and the values calculated are shown in table 5 .
That two-step process of conversion first to Lambert Conic Conformal or State Plane before conversion to UTM did not significantly improve the RMS error when compared with direct transformation to UTM (table 5), although the RMS error remained high despite the direct conversion to UTM. As a result, a shift occurred between the converted DXF and PSGIS shoreline data layers. This shift was visible as two distinct data layers, when both shoreline data layers were viewed on a CRT display at full zoom. The resulting error was not anticipated, because the original data were created in a highly accurate CAD/CAM system.

Different transformation processes of the DXF files to world coordinates were used to decrease this registration error. Early transformation of the PSEA data used only four control points per PSEA region. The final PSGIS tic-data set totaled 312 control points and produced an RMS error greater than 60 meters.

A second iteration transformed each DXF file into a tic set that approximately matched 1 of the 12 corresponding PSEA regional tic sets. That is, instead of using a combined tic set for all 12 PSEA regions, the DXF files for each region were transformed one at a time using their own unique tic set and then combined into one data set. This stepwise transformation of each DXF region into the combined data set also reduced, but did not eliminate, the visible shift and resulting RMS error. As a final test, original Puget Sound Water Quality Authority mylar base maps were acquired and

Table 5. Root-mean-square error, in meters, for data transformation to three projection systems in the Puget Sound Environmental Atlas, Regions 5 and 6

[DXF. Drawing Interchange Format; UTM, Universal Transverse Mercator; measurements given are in meters; RMSE', root-mean-square error]

$\begin{array}{llll}\text { Region DXF coverage name Sambert } & \text { State plane }\end{array}$

5

6

(B5ALL)

(B6ALL)
53.267

43.076
175.050

(2)
53.224

43.030

I Root-mean-square error is a statistical method to determine correlation between two sets of data. The equation for root-mean-square error is:

$$
\begin{aligned}
\text { RMSE } & =\sqrt{\Sigma \frac{(x-y)^{2}}{n}} \\
\text { where } \quad \mathrm{x} & =\text { DXF value } \\
\mathrm{y} & =\text { new projection value } \\
\mathrm{n} & =\text { total number of values }
\end{aligned}
$$

${ }^{2}$ State Plane coordinate system was not used due to the high root-mean-square error for Region 5 of the Puget Sound Environmental Atlas. 
digitized for DXF files lacking data, which included the marine bird and mammal files. When the mylars were registered on the digitizer to the latitude/longitude intersection tics, RMS error values identical to direct transformation to UTM coordinates resulted. Therefore, it was assumed the cause of the shift was incorrect location of the latitude/longitude tics on the published and the digitized PSEA maps. A list of the PSEA regions and the corresponding RMS errors are in table 6.

Individual tic-coordinate error, in both the $\mathrm{x}$ and $y$ directions, is displayed with the ARC TRANSFORM command. The coordinate error records for this transformation are in Appendix D. The range and distribution of individual errors are summarized in figure 14 for both the $\mathrm{x}$ and $\mathrm{y}$ directions.

\section{Extra File Conversion and Registration}

The Extra DXF files for each region contain the kelp and eelgrass information for the habitat data layer of the PSGIS. Although the DXF Extra and DXF Base file conversion process to composite data layers is identical, there are differences in the registration process.

The latitude/longitude grid tics (layer 58) present in the Base DXF data layers were missing from the Extra DXF data layers, resulting in a northward offset for specific Extra data layers when overlaid onto Base data layers.
In addition, three Extra data layers had coordinates that were different from those in the Base data layers. For those three Extra data layers, layer 62 was used for registration because layer 58 was missing. Layer 62 contained cross-hair tics in the upper-left and lower-right corners that were used to create grid-tic lines for correct registration of the Extra data layers to the Base data layers. Once registered, the control tics from the Base data layers were substituted for the tics in the Extra data layer and the transformation process continued in the same manner as for the Base composite data layer.

Data layers for PSEA Regions 2, 3, and 4 did not have plotting grid tics and virtually no geographic controls to register to the Base data layers or to transform to UTM coordinates. Those data layers were transformed to UTM coordinates by substituting the Base data layer control tics without matching the Extra data layer to the Base data layer. Once in UTM, the desired data layers for kelp and eelgrass were manually fitted by visually placing the beds on the corresponding UTM Base data layer. Although there is no method to measure the accuracy of this placement, it was the only alternative for PSEA Regions 2, 3, and 4 of the Extra files.

\section{Data-Layer Extraction}

The registered PSEA data layers, now in ARC/ INFO format with UTM coordinates, contained cartographic representations of the Puget Sound area resources.

Table 6. Root-mean-square error, in meters, for latitude/longitude tics on Puget Sound Environmental Atlas regional maps [RMSE ${ }^{(1)}$, root-mean-square error]

\begin{tabular}{cccccc}
\hline Region & RMSE & Region & RMSE & Region & RMSE \\
\hline 1 & 27.073 & 5 & 53.224 & 9 & 13.448 \\
2 & 36.650 & 6 & 43.030 & 10 & 12.324 \\
3 & 30.897 & 7 & 13.647 & 11 & 61.771 \\
4 & 12.174 & 8 & 11.846 & 12 & 12.295 \\
\hline
\end{tabular}

' Root-mean-square error is a statistical method to determine the correlation between two sets of data. The equation for root-mean-square error is:

$$
\begin{aligned}
R M S E & =\sqrt{\Sigma \frac{(x-y)^{2}}{n}} \\
\text { where } \quad \mathrm{x} & =\text { Drawing Interchange Format (DXF) value } \\
\mathbf{y} & =\text { new projection value } \\
\mathbf{n} & =\text { total number of values }
\end{aligned}
$$




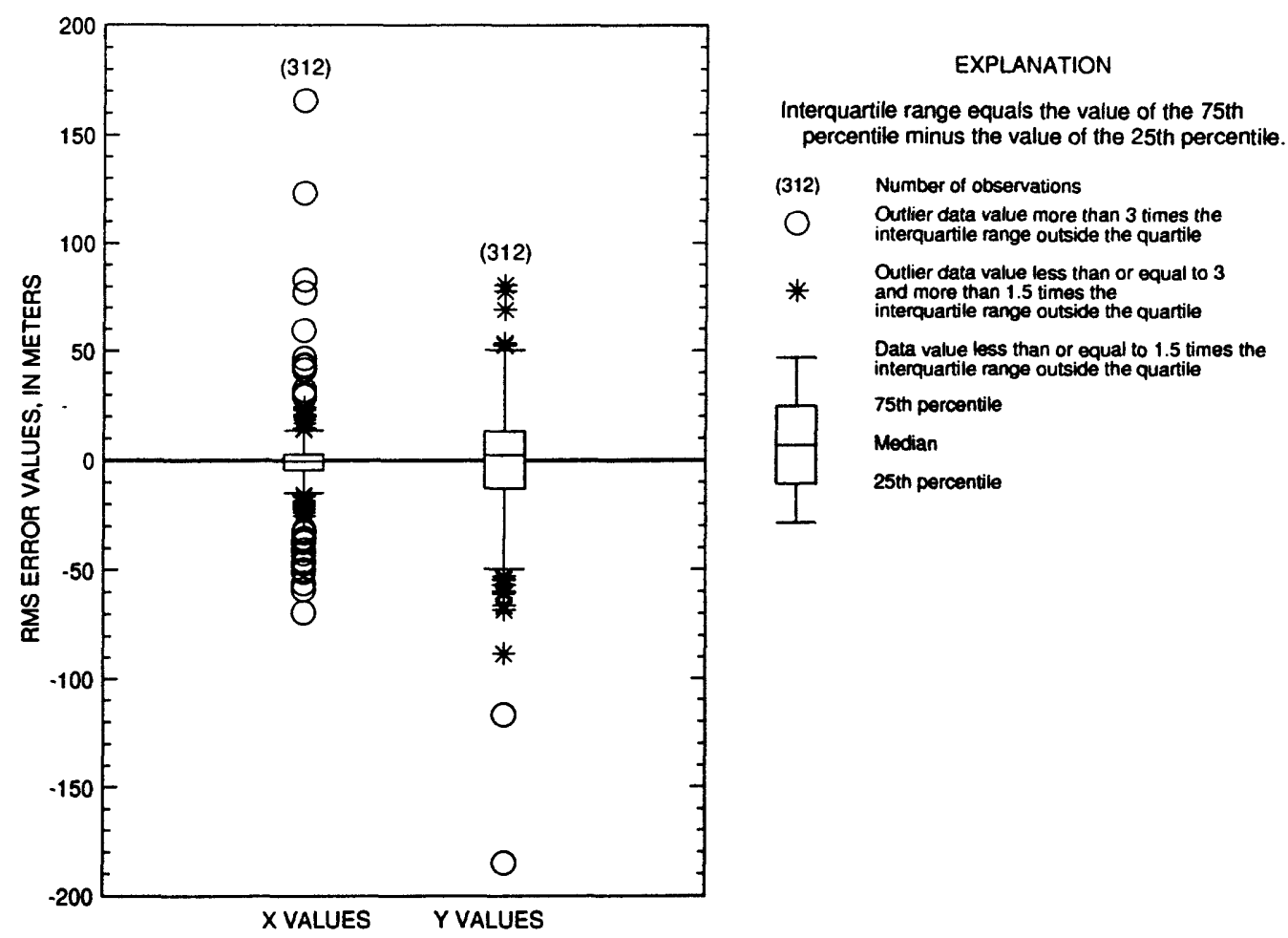

Flgure 14. Root-mean-square error for Base and Extra DXF (Drawing Interchange Format file transformation).

The digital data were a representation of a published PSEA map sheet. For example, an area depicting the location of Dungeness crab resources was filled with angled hachure lines. In a vector GIS environment, this area is represented by a polygon. Once the polygon has been created and topology constructed (gaps are closed, sliver polygons and dangling arcs eliminated), attributes can be assigned for that particular area. The creation of the PSGIS data layers from the PSEA required taking the cartographic representations of areas - such as lines (unbroken and dashed), hachured areas, and symbols — and creating topologically correct, polygon data layers for the desired resources.

PSEA resources were extracted from the composite DXF data layer using the DXF-LAYER INFO item and the ARC RESELECT command to create single, resource data layers. For example, the features with a DXF-LAYER value of 46 contained the cartographic representations of clam, oyster, and geoduck resource areas. Each resource was then extracted into its own data layer for further editing and attribution. There were four possible types of areas that could be extracted from each DXF layer. The following is a description of those areas and the methods used for extraction.

\section{Line-Delimited Areas}

The areas of the PSEA Shellfish Resources maps showing geoduck resources are examples of linedelimited areas. Areas made up of unbroken lines in the PSEA files were easy to select manually (using a CRT display in ARCEDIT) and place into new coverages with the PUT command. Other areas - represented with broken or dashed lines required manual connection before polygon topology could be created. Usually, the dashed lines were selected and put into a new coverage before final editing.

\section{Shoreline Areas}

Beaches where surf smelt spawning occurs are examples of shoreline areas that are indicated by a thick line along the shore with short perpendicular branches pointing landward to distinguish the area from the regular shoreline. To assure feature coincidence with the $100 \mathrm{~K}$ shoreline DLG, a segment of the PSGIS shoreline data layer that matched the geographic extent of the PSEA surf smelt spawning beach was used. These lines were placed into a separate data layer and buffered by 20 meters to create polygons. 
The 20-meter radius was chosen because a smaller radius tended to collapse into lines during later processing. This data layer, now in a GIS with calculated areas, was added to the final Marine resource layer of the PSGIS.

\section{Hachured Areas}

Hachured areas (relief features indicated on a map by short, parallel lines) were the most complex representations in the PSEA data sets. Often, as in layer 46, multiple PSEA resources were represented by hachures of varying angles and separation distances to distinguish resources from one another. Hachure lines indicating the extent of polygons in the data layer can be manipulated by setting up geographic-coordinate relations that give the hachures unique association to resources. Hachure lines for a given resource all run in the same direction. The ARC TURNTABLE command will create a .TRN file in INFO for all of the nodes in the data layer. One of the attributes in the .TRN file is the azimuth of the arcs. This attribute can be used to associate each hachure with a resource. In ARCEDIT, a RELATE was established between the .AAT file and the .TRN file to determine the azimuth of all the arcs of a particular set of hachure lines; that is, all of the arcs for a resource were represented by those hachures. A detailed explanation of that process, in ARC and INFO commands from DXF layer 41 (Dungeness crab areas), is given in Appendix $\mathrm{E}$.

Once individual resource hachures are selected out and placed into their own data layers, a bounding polygon is placed around the area indicated by each set of hachures. An AML (LINEPOLY.AML) procedure was developed to automate this task. LINEPOLY .AML buffered the hachure lines with a buffer distance slightly greater than half the distance between hachures, and then snapped the resulting delimiting polygon back to the nodes at the end points of the hachures. This automatically created a polygon that corresponded to the area represented by the hachures.

\section{Symbol Areas}

Seabird nesting areas, and marine mammal haulout sites and sightings are represented in the PSEA as circles with a number in the center that identifies a particular species in the legend. When converted into real-world coordinates, the circles symbolizing nesting areas become large areas. Because the original information, including the precise coordinates on nesting sites was unavailable, the data were digitized directly from the PSEA. Points were digitized at the center of the circle to represent the nesting site. Additional sites in the PSEA were identified with a pointer line from the circle to a point on the shore. In these cases, a point was created at the end of the pointer line to represent the site. Individual species data layers were created for each PSEA region, and each species was given unique identifiers to facilitate creation and attribution of the final composite.

Because the PSEA resource layers were primarily polygonal features, it was determined that the seabird and marine mammal resources would better match the rest of the PSEA data if polygons were created to represent the information. The points identifying nesting or haul-out sites were buffered with a radius of 20 meters. A label point was maintained in the center of each polygon.

In some instances, the PSEA information represented a length of shoreline, usually indicating a colony - such as pigeon guillemot or harbor seal. The specified shoreline segment was extracted from the 100K-scale Puget Sound Area data layer. This line feature was buffered with a 20 -meter radius to create a polygon feature. Attributes were then assigned to the polygons. The separate bird or mammal data layers were composited together with the ARC UNION command to form the seabird and mammal resource data layer.

\section{Compilation of Puget Sound Environmental Atlas Data}

Individual resource data layers were created and managed in a directory structure organized by PSEA region. Resource data layers within each of the 12 regional directories were assigned the same name. This type of organization facilitates automation of as much of the final editing and attributing as possible. The final coverage ID in the .PAT and .AAT files was attributed with a unique code indicating the resource and the PSEA region. Refer to table 4 for the unique resource ID numbers and data-layer names and definitions.

Unique ID values were calculated by multiplying the region number by 100 , and adding the resource ID number to the product. For example, the following formula would be used to attribute the shrimp data layer in the PSEA region 12 directory: 


\section{CALC SHRIMP-ID $=(12 * 100)+36=1236$}

After the data layers in the PSEA regional directories were completed and checked, the data layers were copied to a resource directory, such as shellfish, and composited into Puget Sound area-wide resource data layers with the UNION command. The UNION command paneled the adjacent PSEA regions together. The ARC DISSOLVE command was applied to the unioned data layer to eliminate the borders of polygons that were located in more than one PSEA region. The dissolved data layers were then composited, again with the UNION command, to produce the final PSGIS resource layer from PSEA data. Based on the unique IDs, attribute fields were added to the composite and then populated. When attribution was complete, unneeded data fields were dropped from the .PAT files. The final products do not have line topology, but if built with the LINE option, the IDs would reflect the origin resource of each line.

The separate uncomposited data layers, used to construct these final composited resource layers, also are provided. Attributes for these individual data layers are the standard Arc Attribute Tables (.AAT) and/or the Polygon Attribute Tables (.PAT), and include a unique item-name matching that of the data layer. For example, the groundfish data layer, as part of the marine fish composited resource layer, has an item in the .PAT called GROUNDFISH which is equal to 25, the unique ID number from table 4.

\section{SUMMARY}

Data from the Puget Sound Environmental Atlas have been converted to the Puget Sound Geographic Information System using the ARC/INFO software. Each data layer is available as a graphic coverage (ARC) with associated tabular data (INFO database), as an individual data layer, and as a composited resource layer composed of these corresponding data layers. Additional environmental data layers, not contained in the Puget Sound Environmental Atlas, also are included in the Puget Sound Geographic Information System. The processing methods used to convert the data layers to a geographic information system are discussed. Sources of error, inherent with any conversion of cartographic data to a geographic information system, also are addressed. The Appendixes contain data dictionaries for data from the Puget Sound Environmental Atlas and other sources, root-meansquare error values for atlas data, tic-coordinate error values, and a detailed list of commands used to manipulate the hachure atlas data. Data can be retrieved by contacting the State of Washington Department of Natural Resources (Division of Aquatic Resources) or the U.S. Geological Survey. 


\section{REFERENCES CITED}

Bonneville Power Administration, 1990, Northwest environmental data base-Long-term data management plan: Portland, Oregon, U.S. Department of Energy, $44 \mathrm{p}$.

Environmental Systems Research Institute, Inc., 1988, An analysis of the Puget Sound environmental atlas: Olympia, Washington, $16 \mathrm{p}$.

1989, ARC/INFO command references: Redlands, California, Volume 2, Version 5.0.1, Appendix D.

1992, Glossary, in Understanding GIS-

The ARC/INFO method: Redlands, California, p. Xxvii-Ixxiii.

Evans-Hamilton, Inc., and D.R. Systems, Inc., 1987, Puget Sound environmental atlas_-Volumes I and II: Seattle, Washington, U.S. Environmental Protection Agency, Puget Sound Water Quality Authority, and U.S. Army Corps of Engineers.

Fisher, B.J., 1996, Methodology used to produce an encoded 1:100,000-scale digital hydrographic data layer for the Pacific Northwest: U.S. Geological Survey WaterResources Investigations Report 94-4043, 84 p.

Horn, C. R., 1986, River-reach file manual (Draft): U.S. Environmental Protection Agency, Washington, D.C., 50 p. [Available from U.S. Environmental Protection Agency, 401 M St. SW, Washington, D.C. 20460]
Nebert, Douglas D., 1989, Review of edgematching procedures for digital cartographic data used in geographic information systems (GIS): U.S. Geological Survey, Open-File Report 89-597, 12 p.

Puget Sound Water Quality Authority, 1990, Implementation plan for the Puget Sound geographic information system: Seattle, Washington, $51 \mathrm{p}$.

1991, Puget Sound water quality management plan: Seattle, Washington, 344 p.

Snyder, John P., 1987, Map projections-A working model: U.S. Geological Survey Professional Paper 1395, 383 p.

U.S. Geological Survey, 1989a, Digital line graphs from 1:100,000-scale maps_-Data users guide 2: Reston, Virginia, $88 \mathrm{p}$.

1989b, Map accuracy: Earth Science Information Center, Reston, Virginia, 2 p.

Washington Department of Ecology, 1986, Water-resources inventory areas subbasins, Washington Administrative Code, Title 173-500-990: Olympia, Washington, p. $490-492$.

Washington Department of Health, 1990, Third annual inventory of commercial and recreational shellfish areas in the Puget Sound: Olympia, Washington, Environmental Health Program, Office of Shellfish Programs, 10 p., 4 maps. 


\section{GLOSSARY}

Albers Equal Area. A conical map projection system with two standard parallels (lines of latitude) along which there is no distortion. The first parallel is at the top of map and the second parallel on the bottom. A central meridian (a true vertical line of longitude usually in the middle of a map) also is used. Areas with predominant east-west expanse are best portrayed.

AML. ARC Macro Language that is modeled after the PRIME ${ }^{2}$ Computer's Command Procedure Language. The AML provides fourth generational programming capabilities and tools using an independent processor. These capabilities include a set of directives and inline functions used interactively or in programs, logical branching and loops, macro- and menu-building tools, and mathematical operations.

Arc. A string of $x, y$ coordinate pairs called vertices that begin at one location and end at a different location. Connecting the vertices creates a line. An arc may represent a linear feature or polygon boundary. A single line feature may contain many arcs.

Arc Attribute Table (.AAT). An INFO (a relational database manager) data file containing the feature attributes for lines (arcs) in a digital map (coverage). These data files also may hold all thematic data for the arc features of a coverage.

ARCEDIT. The graphics (locational) and database (descriptive) editor for the ARC/(INFO) environment. ARCEDIT provides map-digitizing capabilities using computer-aided design functions; allows for editing of features, attributes, and map annotation; and includes commands for rubber sheeting and map-sheet edgematching.

ARC/INFO. A geographic information system and registered trademark of the Environmental Systems Research Institute of Redlands, California. ARC/INFO provides automation, manipulation, analysis and display of geographic data in digital form. The main programming environment (ARC) provides the graphic functions, file management, error check, and verification commands. ARC is combined with INFO-the database manager of the tabular data associated with the geographic information.

ASCII. American Standard Code for Information Interchange. Individual alphanumeric codes represent each of a specific set of 128 numerals, letters, and control characters. Text files created with a text editor of a computer system commonly are referred to as ASCII files.

\footnotetext{
${ }^{2}$ For a more detailed description of terms, see Environmental Systems Research Institute, Inc., 1992.
}

attribute. A descriptive characteristic of a geographical feature, usually stored in a tabular format and linked to that feature by a relational database. The attribute can be numeric, text, or image.

AutoCAD. A computer-aided design program developed by Autodesk, Inc., of Sausalito, California, that is used for automated computer-aided design and drafting functions. The resulting Drawing Interchange Format files are, in turn, used to store and convert vector data to ASCII or binary files.

base map. A map having essential outlines and features of the project area. Additional geographical or topographical data may be overlaid for comparison or correlation.

benchmark. Used in land surveying as a surface point inscribed on a permanent monument to provide a fixed reference control of elevation above a specified datum plane, such as mean sea level.

binary file. A file containing data or program instructions in a computer-readable format. Only the digits 0 and 1 are used.

buffer. Automated procedure to artificially expand a line or point coverage a specified distance in order to create a polygon coverage.

CAD/CAM. Computer-Aided Drafting/Computer-Aided Manufacturing. Several CAD/CAM systems include major features for a geographic information system and automated design, drafting, mapping, and display of graphically oriented information.

cartographic base. Term for planimetric base maps that show the correct horizontal position of natural resource features.

centerlines. A feature or process (centerlining) used for routing purposes in which cartographic features, such as the banks of a lake or large stream are replaced by a single line. The procedure can be automated with a resulting line at the calculated center of the lake or stream or hand-edited to approximate the center route position of the feature.

clip. An ARC/INFO process used to extract spatial features from one coverage that reside within the boundary of another coverage known as the clip cover. Clipping works much like a cookie cutter.

coincident. Lines or arcs that occur as cartographic duplicates of each other. Usually, one set of arcs is deleted.

coordinate. A pair of measurements, used from a planimetric system denoting horizontal $(x)$ and vertical (y) locations, usually defined by a particular map projection, datum, central meridian, or standard parallel. 
coverage. A digital version of a map forming the basic unit of vector-data storage in ARC/INFO.

COVER-ID. A user-assigned INFO integer item, found in feature attribute tables such as .AAT or .PAT files, that identifies arc or polygon features in the coverage.

CRT display. The screen of a cathode-ray tube in a computer monitor that is used to view alphanumeric and graphic output.

dangling arcs. An arc with the identical polygon on its left and right side and with at least one node not connected to another arc. Usually the arc is short in length and results from overshoots during digitizing.

design file. Interactive graphics design software file that contains information about $\mathrm{CAD}$ processing parameters such as level, color, element type, and line style and weight.

digitize. To encode map features as $\mathrm{x}, \mathrm{y}$ coordinates in a digital form by using an electron-digitizing tablet. Features are encoded using a digitizing cursor that registers spatial position, thereby defining the shape or location of a feature.

double-banked. Describes larger streams in the Pacific Northwest River Reach data layer that digitally occur as two separate sides or lines. Although dependent on resolution of data, smaller streams generally occur as single lines or arcs. Lakes, when digitally connected to larger streams, also are considered double-banked.

DXF. Drawing Interchange Format. A format for storing vector data in ASCII or binary files that is used by AutoCAD and may be converted to ARC/NNFO coverages.

edgematching. A procedure to digitally link adjacent quadrangle maps by adjusting selected features along a common map edge. Usually executed before map sheets are joined in order to create a smooth and continuous final product.

export. An ARC command that converts an ARC/INFO coverage or file to an interchange file for transfer to another platform running $\mathrm{ARC} / \mathrm{INFO}$.

FIPS codes. Federal Information Processing Standard integer codes for identifying a State or county.

grid tic lines. A coverage generated using longitude and latitude values to identify intersections and connecting lines.

hachures. A series of several, short parallel representing a resource feature.

hydrologic unit code (HUC). A coding system, developed by the U.S. Geological Survey, that uses an 8-digit integer comprised of regional, subregional, accounting, and cataloging unit numbers to identify drainage basins. import. An ARC command that converts an ARC/INFO interchange file (usually an exported coverage) into an ARC/INFO coverage and associated INFO data files.

Intergraph. Is a geographic information system AutoCAD software program and a registered trademark of Intergraph Corporation of Huntsville, Alabama.

label point. An ARC/INFO feature used to represent either a point feature or to identify a polygon. The point is stored as a single $x, y$ location with assigned identification numbers and other attributes. When identifying polygons, the point can occur anywhere within the polygon.

Lambert Conformal Conic. A conical map projection in which parallels are unequally spaced and meridians equally spaced. Distances are true only along standard parallels. Lambert Conformal Conic is widely used for many U.S. Geological Survey topographic maps and is used best for areas with a predominant east-west expanse. Distortion of shapes and areas is minimal.

map projection. A mathematical model that transforms locations from the surface of the Earth, a threedimensional spheroid, to locations on a planar twodimensional surface. The three basic types of map projection are cylindrical, azimuthal, and conic.

megabytes. A byte is a group of binary digits, usually eight, stored as memory and data units which measure file size. A megabyte is 1 million bytes and contains values of 0 to 255 .

Mercator. A cylindrical map projection with true distances only along the Equator with distortion increasing substantially toward the poles. Because of the distance from the equator, areas and shapes of large regions are distorted. Used in equatorial navigation maps with rhumb lines (lines of constant direction) for direction.

networks. A linear data layer of interconnected arcs, representing possible paths or routes for the movement of resources from one location to another.

node. The digital start or end of an arc. A node is the point where three or more arcs connect, is topologically linked to all arcs that meet at the same point, and is the point at which lines connect in a polygon network or a triangular irregular network.

paneling. A geographic information system process that appends contiguous digital map files into a single map coverage. The $100 \mathrm{~K}$ Digital Line Graphs from National Mapping Division are distributed as a series of 32 contiguous map files. A macro program called DLGPANEL processes these map files into a single coverage by using the ARC DLGARC, APPEND, and MATCHNODE commands. Paneling is a colloquial term used to describe this process. 
planimetric map. A map indicating only the horizontal positions of features without regard to elevation, in contrast with a topographic map that indicates both horizontal and vertical positions.

Polyconic. A conical map projection, used for largescale maps of the United States until the 1950's, with distances true only along each parallel and the central meridian. Because direction is true only at the central meridian, the best application of polyconic map projection is in areas with a north-south expanse.

polygon. A multisided, closed figure that represents an area on a map. An areal feature defined by the arcs that make up the polygon boundary. Every polygon contains one label point inside its boundary.

pseudo nodes. An ARC/INFO term that describes the location where only two lines or arcs intersect, or where a single arc connects with itself.

registration. An ARC/INFO process where a coverage is either created or edited using a digitizer.

Tic-identification numbers and locations (at least 4) must first be entered at the digitizer and a root-meansquare error calculated. If the root-mean-square error is within acceptable tolerances, features can then be added or edited.

relational database. A collection of information that is structured as tables that can logically interrelate to other tables by shared attributes. If the name of the table, the attribute name, and the value of the related item are known, any data element can be found in a relational database.

RMS error. Root-Mean-Square (RMS) error is used primarily in the ARC/INFO geographic information system for tic registration and represents the amount of error between the original and new coordinate locations. The general rule is to keep the RMS error below 0.004 when digitizing.

routing. A process whereby ordered collections of arcs or parts of arcs are used to represent linear features. A single line coverage can contain many route systems,

such as a river or highway network. For example, stream or road quality features or events can be positioned along routes and later located by attributes such as distance measurements.

shellish. An aquatic animal, such as mollusks (clams and geoducks) or crustacean (crabs and shrimp) that possesses a shell or shell-like exoskeleton.

sliver polygons. A small areal feature frequently occurring along polygon boundaries when two or more coverages are overlain. The boundaries may not match exactly because of resolution or registration differences occurring during coverage generation. snapping. An ARC/INFO process of moving a featuresuch as a node or arc - to coincide exactly with coordinates of another feature, thereby connecting the two features. A connecting distance is usually specified. Snapping can occur on any of the features-arc, node, label, tic, and annotation.

State Plane coordinate system. A defined set of coordinate systems that vary from State to State. They are not themselves map projections, and are normally used only in conjunction with certain types of map projections. Each State is divided into zones and each zone has different sets of parameters, such as the central meridian and origin of coordinates. States with an east-west expanse use Lambert Conformal Conic projection. States with a north-south orientation use Universal Transverse Mercator projection.

STORET. A STOrage and RETrieval database for waterquality information established and maintained by the U.S. Environmental Protection Agency.

stream mode. A technique used with some digitizing hardware that allows continuous input of data points by constant depression of the cursor button instead of manually entering each point (intermittent-mode). The rate (in points per second) at which data points are entered usually can be selected.

tics. A geographic control point used in ARC/INFO coverages that represents known locations on the surface of the Earth. Map sheets are registered to tics and then firmly affixed to a digitizing table. The digitizer units are transformed to coverage units, usually the projection units, thereby providing a common reference system for all coverage features.

tile. A spatial unit by which geographic data is stored and organized. The structure can be regular, as with the 100K-scale quadrangle Digital Line Graphs or irregular, as with the U.S. Geological Survey hydrologic unit codes.

topological method. The method in which geographic features, such as arcs, nodes, polygons, and points, are linked together to define the spatial relation between connecting and adjacent features. This method includes the from- and to-nodes, and the left and right polygons of an arc. Redundant coordinates, such as an arc coordinate used as both a linear and a polygon feature, are deleted when topology is developed. These spatial relations are often complex and are defined mathematically as area, connectivity, and contiguity.

transformation. A process by which the coordinates of a single data layer are converted from one system to another. Transformation is commonly used to convert a coverage in digitizer units (usually inches) to a map projection system, such as Universal Transverse 
Mercator meters. The ARC/INFO TRANSFORM method uses scaling; rotation; $\mathbf{x}, \mathbf{y}$ shifts; polynomials for warping images; and root-mean-square errors to calculate and convert to a new coordinate system.

Universal Transverse Mercator (UTM). A coordinate system defined by the Transverse Mercator projection (cylindrical type) and a set of zones and offsets.

Distortion of the coordinate system increases away from the central meridian. This system is used in USGS $250 \mathrm{~K}$-scale quadrangle maps; UTM is not used for large areas. Puget Sound is within Zone 10. Zone 10 ranges in longitude from $126^{\circ} \mathrm{W}$ to $120^{\circ} \mathrm{W}$; the central meridian is $123^{\circ} \mathrm{W}$.

VAX. Geographic information system work station from the Digital Equipment Corporation. vector. A data structure represented by linear map features ordered by a set of $x, y$ coordinates. Another data structure, called raster, is cell-based. A vector-coordinate system assigns attributes to features, whereas a rastercoordinate system assigns grid cells to the attributes.

weeded. An ARC/INFO processing term that eliminate vertices along an arc within a specified distance.

zone. The relation of a section or region of the Earth, the United States, or a State of the United States to a particular map projection. Universal Transverse Mercator map projections divide the entire world into 60 zones; State Plane zones are assigned to each state, and larger states are divided into more than one zone. For example, Washington has two State Plane Zones (north-5601 and south-5626). 
APPENDIXES 


\section{APPENDIXES}

The appendixes are generated by the DOCUMENT Command, a user contributed ARC library function (D.D.Nebert, U.S. Geological Survey, written commun., 1991). These appendixes provide additional information about individual data layers and are specific in content. Such information may include a detailed list of processing steps used in generating a data layer, attribute item names used, persons and telephone numbers to contact for additional information, map projection, and scale and resolution used. In some cases, portions of the appendixes acquired from the document.aml may be edited or deleted if information is duplicated from the main body of the report. For example, processing steps that are previously covered in the main text may either be reclarified or eliminated from the appendixes.

Much of what follows is output from the INFO data base, the header information is normally abbreviated and is explained below. This header listing is identical for all INFO files used in this report:

COLUMN: The column in which data-field begins.

ITEM NAME: The name given to the attribute, can be user or INFO derived.

WIDTH: $\quad$ Number of spaces or columns for storing item values.

OUTPUT

WIDTH: $\quad$ Number of spaces or columns to display item values.

TYPE: The item types used in this report are:

$F=$ internal floating point, $B=$ binary, $I$ = integer, $\mathrm{N}=$ real number, $\mathrm{C}=$ character

NUMBER OF

DECIMALS: The number of decimal spaces for numeric items.

DEFINITION: This category added to clarify items, not INFO derived. 
The standard INFO files for Arc Attribute Tables (.AAT) and the Polygon/Point Attribute Tables (.PAT) are identical for many of the data layers in this report. In order to save text space, these standard INFO. .AAT or . PAT files are not listed. The banner "STANDARD .AAT or .PAT FILE" appears in its place. The standard INFO .AAT and. PAT files are listed below. The name COVERAGE is used in place of the actual coverage or data layer name. If items in addition to the standard items are present they will occur after the banner.

STANDARD . AAT FILE

\begin{tabular}{|c|c|c|c|c|c|}
\hline COL & ITEM NAME & WDTH & OPUT & TYP & N.DEC DEFINITION \\
\hline 1 & FNODE\# & 4 & 5 & B & Internal number of from-node \\
\hline 5 & TNODE\# & 4 & 5 & B & Internal number of to-node \\
\hline 9 & LPOLY\# & 4 & 5 & B & $\begin{array}{l}\text { Internal number of polygon to } \\
\text { left of arc }\end{array}$ \\
\hline 13 & RPOLY\# & 4 & 5 & B & $\begin{array}{l}\text { Internal number of polygon to } \\
\text { right of arc }\end{array}$ \\
\hline 17 & LENGTH & 4 & 12 & F & Length of arc in meters \\
\hline 21 & COVERAGE\# & 4 & 5 & B & Internal feature number \\
\hline 25 & COVERAGE - ID & 4 & 5 & $\mathrm{~B}$ & - User-assigned feature number \\
\hline
\end{tabular}

STANDARD . PAT FILE

(Polygon/Point)

\begin{tabular}{rlccccc}
\hline COL & ITEM NAME & WDTH & OPUT TYP N.DEC DEFINITION \\
1 & AREA & 4 & 12 & F & 3 & $\begin{array}{c}\text { Area of polygon in square } \\
\text { meters }\end{array}$ \\
5 & PERIMETER & 4 & 12 & F & 3 & $\begin{array}{c}\text { Perimeter of polygon in meters } \\
9\end{array}$ \\
COVERAGE\# & 4 & 5 & B & - & Internal feature number \\
13 & COVERAGE-ID & 4 & 5 & B & - User-assigned feature number
\end{tabular}

9 (Area and Perimeter for point coverages equal zero) 


\section{APPENDIX A \\ Data-Layer Dictionary of Environmental Data for the Puget Sound Area from Sources Other Than the Puget Sound Environmental Atlas}

\section{Shoreline}

DOCUMENTATION FOR DATA LAYER: Shoreline, coverage name; SOUND SOURCE REFERENCE: U.S. Geological Survey-National Mapping Division (USGS-NMD) 1:100,000-scale Digital Line Graphs MAP PROJECTION: UTM, Zone 10

PRECISION: Single

TOLERANCES: Fuzzy $=.001$ Dangle $=1.0$

THEME: Puget Sound Shoreline

DESCRIPTION: The Puget Sound Shoreline was extracted from the

Pacific Northwest (PNW) River Reach data set.

CONTACT PERSON/S: Mark Uhrich

CONTACT INSTRUCTIONS: Uhrich 503-251-3292

ORGANIZATION: U.S. Geological Survey (USGS)

LOCATION DESCRIPTION: Northwest Washington, Puget Sound shoreline Longitude: $125^{\circ}-122^{\circ}$, Latitude : $47^{\circ}-49^{\circ}$

RESOLUTION: $167 \mathrm{ft}(50.9 \mathrm{~m})$

SCALE: $1: 100,000$

ARCHIVE LOCATIONS: Puget Sound Water Quality Authority (PSWQA); Washington Department of Natural Resources (DNR), Division of Aquatic Resources

INFO ITEM DEFINITIONS FOR SOUND.PAT FILE:

COL ITEM NAME WDTHOPUT TYP N.DEC DEFINITION

17 SOUND

$$
\text { STANDARD . PAT FILE (POlygon) }
$$

11 I - Polygons with SOUND $=1$ are embayment water bodies;

(69 polygons), polygons with sound $=0$ are land; (271 polygons)

INFO ITEM DEFINITIONS FOR SOUND. AAT FILE:

STANDARD . AAT FILE 
Abstract - The Puget Sound Shoreline was extracted from the 1:100,000-scale (100K) DLG's to provide the Puget Sound Geographic Information System (PSGIS) with a uniform shoreline data set. The Sound coverage was used as a template in a number of coverages, including embayments, tribes, and the shellfish inventory. In some Puget Sound Environmental Atlas (PSEA) data layers it was used as an erase coverage.

Processing steps- The Puget Sound shoreline layer was constructed from each of the PNW River Reach Hydrologic Unit Code (HUC) coverages (17110001-17110021). HUC coverages were created from USGS-NMD 100K Hydrology DLG's. River Reach attributes were not needed in this layer and were deleted. A flag item denoting water or land (SOUND) was added. Most all of the shoreline was acquired from the River Reach project network coverages, but some segments were missing and were found in the "banks" coverages. To ensure the entire Puget Sound was topologically one polygon required considerable editing of the shoreline arcs. The ARC log files that accompany this coverage also contain details on the ARC commands used along with additional notes entered at the time of processing.

Reference:

U.S. Geological Survey, 1989, Digital line graphs from 1:100,000-scale maps-Data users guide 2: Reston, Virginia, 88 p. 


\section{Water-Body System}

DOCUMENTATION FOR DATA LAYER: Embayments SOURCE REFERENCE:USGS-NMD, 1:100,000-Scale Digital Line Graphs MAP PROJECTION: UTM, ZONe 10

PRECISION: Single

TOLERANCES: Fuzzy $=.001$ Dangle $=1.0$

THEME: Puget Sound Embayments

DESCRIPTION: The Puget Sound was divided by the Washington Department of Ecology (DOE) into significant water bodies by adding artificial boundaries to shorelines on National Oceanic and Atmospheric Administration (NOAA) navigational maps. A series of NOAA maps were used as base maps that include the entire Puget Sound. The NOAA Map Series number is provided in the "Additional notes" section. Embayments areas uniquely define significant water-body systems and estuarine areas.

CONTACT PERSON/S: Mark Uhrich(1), or Tom Gries (2)

CONTACT INSTRUCTIONS: 1 . Uhrich 503-251-3292

2. Gries 360-407-7536

ORGANIZATION: 1.USGS 2. Washington DOE, Sediment Management Unit LOCATION DESCRIPTION: Puget Sound shoreline Longitude: $122^{\circ}-125^{\circ}$, Latitude $: 47^{\circ}-49^{\circ}$

RESOLUTION: $167 \mathrm{ft}(50.9 \mathrm{~m})$

SCALE : $1: 100,000$

ARCHIVE LOCATIONS:PSWQA; Washington DNR, Division of Aquatic Resources

INFO ITEM DEFINITIONS FOR EMBAYMENTS.PAT FILE:

COL ITEM NAME WDTH OPUT TYP N.DEC DEFINITION

$$
\text { STANDARD . PAT FILE (POlygon) }
$$

17 SQMILES $\quad 8 \quad 16 \quad$ F 2 Area of embayment polygon in square miles

25 EMBAYMENT\# $\quad 4 \quad 4 \quad$ N 1 U.S. Environmental Protection Agency (USEPA)/Washington DOE number for each Embayment polygon

29 SOUND $\quad 1 \quad 1 \quad I$ - Polygons with SOUND $=1$ are embayment water bodies (69 polygons), polygons with SOUND $=0$ are land (271 polygons)

INFO ITEM DEFINITIONS FOR EMBAYMENTS.AAT FILE: STANDARD .AAT FILE 
Abstract - The USEPA and Washington DOE delimited a water-body system for the entire Puget Sound. The system includes 69 significant embayments and estuarine areas constructed by enclosing the water bodies with artificial closure lines. These closure lines were digitized into the SOUND shoreline coverage of the Puget Sound. Labels were added to each of the embayment areas and an area value in square miles was calculated.

Processing steps- The Puget Sound shoreline layer was constructed from each of the PNW River Reach HUC coverages (17110001-

17110021). HUC coverages were created from USGS-NMD 100K Hydrology DLG's. River Reach attributes were not needed in this layer and were dropped. Items for embayment area in square miles, embayment number and a flag for water or land (SOUND) were added. Most of the shoreline was acquired from the PNW River Reach network coverages, missing segments were added from the "banks" coverages. To create a single, topologically correct polygon for the entire Puget sound required considerable editing of the shoreline arcs. The ARC log files that accompany this coverage contain more details on the ARC processing used. The artificial embayment lines were digitized from lines drawn by the Washington DOE on six NOAA nautical maps of varying map projections and scales (see "Additional notes"). Embayment lines were given -ID code $=9999$ and artificial lines drawn to close river mouths had - ID codes $=9998$. A small piece of San Juan Island (northeast corner of Port Angeles), missing from the DLG data was digitized from the $100 \mathrm{~K}$ quad sheet (-ID = 9999). The NOAA nautical maps were digitized in their respective projections, then projected into UTM before registering with the embayment shoreline coverage.

\section{Reference:}

U.S. Geological Survey, 1989, Digital line graphs from 1:100,000-scale maps-Data users guide 2: Reston, Virginia, 88 p.

Additional notes:

Name

NOAA CHART 18421

NOAA CHART 18424

NOAA CHART 18427

NOAA CHART 18441

NOAA CHART 18448

NOAA CHART 18465

$\begin{array}{lc}\text { Projection } & \text { Scale } \\ \text { Mercator } & 1: 80000 \\ \text { Polyconic } & 1: 40000 \\ \text { Mercator } & 1: 80000 \\ \text { Mercator } & 1: 80000 \\ \text { Mercator } & 1: 80000 \\ \text { Mercator } & 1: 80000\end{array}$




\section{Shellfish Inventory}

\section{Shellfish Growing Areas}

DOCUMENTATION FOR DATA LAYER: DOH_Shell

SOURCE REFERENCE: Washington Department of Health (DOH), Shellfish Inventory.

MAP PROJECTION: UTM, Zone 10

PRECISION: Single

TOLERANCES : Fuzzy $=.001$ Dangle $=1.0$

THEME: Puget Sound Shellfish Inventory and Status

DESCRIPTION: This data layer includes status definitions for shellfish resources and aquaculture harvest areas.

The four classification types as defined by the Washington DOH, Office of Shellfish Programs are: Approved, Conditionally Approved, Restricted, and Prohibited.

CONTACT PERSON/S: Mark Uhrich(1) or

Don Lennartson(2)

CONTACT INSTRUCTIONS: 1 . Uhrich 503-251-3292

2. Lennartson 360-586-8127

ORGANIZATION: 1. U.S. Geological Survey-Water Resources Division (USGS - WRD)

2. Washington $\mathrm{DOH}$

LOCATION DESCRIPTION: Puget Sound Basin

Longitude: $125^{\circ}-120^{\circ}$, Latitude: $46^{\circ} 30^{\prime \prime}-49^{\circ}$

RESOLUTION: $167 \mathrm{ft}(50.9 \mathrm{~m})$

SCALE: $1: 100,000$

ARCHIVE LOCATIONS: PSWQA; Washington DNR, Division of Aquatic Resources

INFO ITEM DEFINITIONS FOR DOH_SHELL.PAT FILE:

COL ITEM NAME WDTH OPUT TYP N.DEC DEFINITION

STANDARD .PAT FILE (Polygon)

17 AREA_STAT 2424 C - Area status (e.g., commercial, approved, restricted, conditionally approved, prohibited)

INFO NAME DEFINITIONS FOR DOH_SHELL.AAT FILE:

$$
\text { STANDARD . AAT FILE }
$$


Abstract - The Washington DOH, Shellfish Programs, 1990 Shellfish Inventory was digitized. The Inventory identifies the use areas and status for commercial and recreational shellfish beds.

Processing steps - The 1990 Shellfish Inventory Maps were created by mapping the status areas on four NOAA base maps in Mercator or Polyconic projection and later reproduced on large-format, commercial photocopies. The ARCPLOT command: MAPPROJECTION was used to convert the UTM "Clipped" portions of the SOUND coverage to match the four NOAA maps. These paper maps were used as templates from which to digitize the shellfish resources. Overlapping did occur with the commercial classification layer and other classification layers. These classifications were listed under the INFO item AREA_STAT as Commercialprohibited, Commercialconditional and Commercialrestricted. See non-PSEA processing procedures in the main text.

Reference:

Washington Department of Health, 1990, Third annual inventory of commercial and recreational shellfish areas in the Puget sound: Olympia, Washington, Environmental Health Program, Office of Shellfish Programs, 10 p., 4 maps. 


\section{Recreational Shellfish Beaches}

DOCUMENTATION FOR DATA LAYER: DOH_REC

SOURCE REFERENCE: Washington DOH, 1990 Shellfish Inventory

MAP PROJECTION: UTM, Zone 10

PRECISION: Single

TOLERANCES: Fuzzy $=.001$ Dangle $=1.0$

THEME: Puget Sound Recreational Shellfish Beaches.

DESCRIPTION: This data layer includes Recreational Shellfish

Beaches from Washington DOH, 1990 Shellfish

Inventory. State Park beaches, Washington DNR

beaches, and County beaches are included.

CONTACT PERSON/S: Mark Uhrich (1) or

Don Lennartson (2)

CONTACT INSTRUCTIONS: 1. Uhrich 503-251-3292

2. Lennartson 360-586-8127

ORGANIZATION: 1. USGS-WRD, 2. Washington DOH

LOCATION DESCRIPTION: Puget Sound Basin

Longitude: $125^{\circ}-120^{\circ}$, Latitude: $46^{\circ} 30^{\prime \prime}-49^{\circ}$

RESOLUTION: $167 \mathrm{ft}(50.9 \mathrm{~m})$

SCALE: $1: 100,000$

ARCHIVE LOCATIONS: PSWQA; Washington DNR,

Division of Aquatic Resources

INFO ITEM DEFINITIONS FOR DOH_REC.PAT FILE:

COL ITEM NAME WDTH OPUT TYP N.DEC DEFINITION

STANDARD . PAT FILE (Point)

17 BEACH\# $\quad 4 \quad 4 \quad$ C - Washington DOH Shellfish

Inventory Beach number

21 STATEPARK 11 I - Indicator flag: 1 = State park,

$0=$ Washington DNR or

County park

22 DNRPARK

11 I - Indicator flag:

1 = Washington DNR park,

0 = state or County park

23 COUNTYPARK 111 I - Indicator flag:

1 = County park, 0 = state or Washington DNR park

24 NAME

3030 C - Recreational beach or park name.

INFO NAME DEFINITIONS FOR DOH_REC.AAT FILE:

$$
\text { STANDARD . AAT FILE }
$$


COVERAGE NARRATIVE:

Abstract - The Washington DOH, Shellfish Programs, 1990 Shellfish Inventory was digitized. The Inventory depicts recreational shellfish beaches, along with the use areas and status for commercial and recreational shellfish beds.

Processing steps - Attributes were added to the beach location points to indicate the Shellfish Inventory beach number (BEACH\#), Agency responsible for the park or beach (STATEPARK, DNRPARK, COUNTYPARK, as well as the name of the park or beach (NAME).

Reference:

Washington Department of Health, 1990, Third annual inventory of commercial and recreational shellfish areas in the Puget sound: Olympia, Washington, Environmental Health Program, Office of Shellfish Programs, 10 p., 4 maps.

\section{Sewage Treatment Outfalls}

DOCUMENTATION FOR DATA LAYER: DOH_SEWAGE

SOURCE REFERENCE: Washington DOH, 1990 Shellfish Inventory

MAP PROJECTION: UTM, Zone 10

PRECISION: Single

TOLERANCES: Fuzzy $=.001$ Dangle $=1.0$

THEME: Puget Sound Shellfish Inventory and status

DESCRIPTION: This data layer identifies the 1990 washington DOH Shellfish Inventory sewage treatment plant outfall locations.

CONTACT PERSON/S: Mark Uhrich(1) or

Don Lennartson (2)

CONTACT INSTRUCTIONS: 1 . Uhrich 503-251-3292

2. Lennartson 360-586-8127

ORGANIZATION: 1. USGS-WRD, 2. Washington DOH

LOCATION DESCRIPTION: Puget Sound Basin

Longitude: $125^{\circ}-120^{\circ}$, Latitude: $46^{\circ} 30^{\prime \prime}-49^{\circ}$

RESOLUTION: $167 \mathrm{ft}(50.9 \mathrm{~m})$

SCALE: $1: 100,000$

ARCHIVE LOCATIONS: PSWQA; Washington DNR, Division of Aquatic Resources 
INFO ITEM DEFINITIONS FOR DOH_SEWAGE.PAT FILE:

COL ITEM NAME WDTH OPUT TYP N.DEC DEFINITION

STANDARD . PAT FILE (Point)

17 PLANT\# $\quad 2 \quad 2 \quad$ C $\quad$ - Municipal sewage treatment plant number

19 NAME $\quad 3030 \mathrm{C}$ - Municipal sewage treatment plant name

INFO NAME DEFINITIONS FOR DOH_SEWAGE.AAT FILE:

STANDARD . AAT FILE

COVERAGE NARRATIVE:

Abstract - The Washington DOH, Shellfish Programs, 1990

Shellfish Inventory was digitized. The Inventory identifies the outfalls for sewage treatment plants, along with use areas and status for commercial and recreational shellfish beds.

Processing steps - Attributes were added to denote the Municipal sewage treatment plant number assigned by Washington DOH (PLANT\#) and name (NAME). Sewage outfalls were mapped using a triangular symbol. Outfall positions were digitized as points at the approximate center of each symbol.

Reference:

Washington Department of Health, 1990, Third annual inventory of commercial and recreational shellfish areas in the Puget Sound: Olympia, Washington, Environmental Health Program, Office of Shellfish Programs, 10 p., 4 maps. 


\section{Upland Hydrography}

\section{General Hydrography}

DOCUMENTATION FOR DATA LAYER: HY."ABBREVIATED QUADRANGLE NAME" (See Additional Notes for Quadname abbreviations) SOURCE REFERENCE: USGS-NMD 1:100,000-scale Digital Line Graphs MAP PROJECTION: UTM

PRECISION: Single

TOLERANCES: Fuzzy $=.001$ Dangle $=1.0$

THEME: Puget Sound Hydrography

DESCRIPTION: Digital Hydrography for the Puget Sound Basin, $1: 100,000$ scale quadrangles (18 quads)

CONTACT PERSON/S:Mark Uhrich or Bruce Fisher

CONTACT INSTRUCTIONS: Uhrich 503-251-3292

Fisher 503-251-3228

ORGANIZATION : USGS-WRD

LOCATION DESCRIPTION: 18 100K quadrangles covering

Longitude: $125^{\circ}-120^{\circ}$, Latitude: $46^{\circ} 30^{\prime \prime}-49^{\circ}$

USGS Hydrologic Units $171100(01-21)$

RESOLUTION: $167 \mathrm{ft}(50.9 \mathrm{~m})$

SCALE : $1: 100,000$

ARCHIVE LOCATIONS: PSWQA; USGS-WRD; USEPA, Seattle

INFO ITEM DEFINITIONS FOR HY."QUADNAME".PAT FILE:

COL ITEM NAME WDTH OPUT TYP N.DEC DEFINITION STANDARD . PAT FILE (Polygon)

17 MAJOR 1

I - NMD feature classifier. Major1

$=50$ is combined hydrography category, Major1 $=170$ is transportation

23 MINOR1 616 I - NMD feature classifier. Minor1 $=412$ is stream, Minor1 $=999$ is artificial reach

29 MINOR2 $\quad 6 \quad 6 \quad$ I $\quad$ - NMD feature classifier. Minor2 $=610$ is ephemeral, Minor2 = 9999 is river mouth closure

35 MINOR3 $\quad 6 \quad 6 \quad$ I $\quad$ - NMD feature classifier. Used as a placer for some processing steps

41 HUC

$8 \quad 8$ I - USGS Hydrologic Unit Code. Puget Sound codes $=$ $17110001-17110021$

49 STR-NAME $\quad 30 \quad 30 \quad \mathrm{C} \quad$ - Stream name from NMD $100 \mathrm{~K}$ Digital Line Graphs or USEPA $250 \mathrm{~K}$ Trace files 
INFO NAME DEFINITIONS FOR HY."QUADNAME".AAT FILE:

COL ITEM NAME

29 MAJOR1

35 MINOR1

41 MINOR2

47 MINOR3

53 HUC

61 SEG

65 RMI

70 LEVEL

72 SEQNUM

83 FLAGS

88 STR-NAME

118 STATE

122 COUNTY

137 QUAD100

163 QUAD75

$188 \mathrm{RRN}$
WDTH OPUT TYP N.DEC DEFINITION

$$
\text { STANDARD . AAT FILE }
$$

$6 \quad 6$ I - NMD feature classifier. Major1 $=50$ is combined hydrography category, Major1 $=170$ is transportation

$6 \quad 6$ I - NMD feature classifier. Minor1 $=412$ is stream, Minor1 $=999$ is artificial reach

NMD feature classifier. Minor2 $=610$ is ephemera1, Minor $2=$ 9999 is river mouth closure

66 I - NMD feature classifier. Used as a placer for some processing steps

8 I - USGS Hydrologic Unit Code. Puget Sound codes = $17110001-17110021$

USEPA segment number. $\mathrm{HUC}+\mathrm{SEG}=$ unique reach id

$5 \quad 5 \quad \mathrm{~N} 2$ River mile index calculated for same numbered SEG reaches. Base reach numbers begin with 0.0

22 I - USEPA assigned stream level. Tributary is one level higher than mainstream. Uses reverse strahler order

1111 C - USEPA hydrologic sequence number. Most upstream reaches have lowest numbers

$5 \quad 5 \quad \mathrm{C}$ - USEPA item used for routing. EX: Transport reaches $=1$, shoreline $=0$

3030 C - Stream name from NMD $100 \mathrm{~K}$ Digital Line Graphs or USEPA 250K Trace files

44 C - State reach falls within

$1515 \quad \mathrm{C}$ - County reach falls within

2626 C - USGS $100 \mathrm{~K}$ quad reach falls within

2525 C - USGS 7.5 min quad reach falls within

1717 C - HUC + SEG + RMI 
COVERAGE NARRATIVE:

Abstract - The hydrography data layer provides the river, stream and channel lines (arcs) with lake and waterway boundaries (polygons) in a $100 \mathrm{~K}$ tile structure projected in UTM for Zone 10. Along with other Geographic Information System (GIS) data layers, the hydrography data layer will be used to assess the resources, demographics and environmental conditions of the Puget Sound Basin. Processing steps- The original NMD 100K Digital Line Graphs were not used for the Puget Sound general hydrography layer for two reasons: (1) the lack of attributes, such as stream-name and USEPA codes, and (2) edgematching and paneling the DLG hydrography had already been done for the River Reach project. The PNW River Reach study supplied data for the Puget Sound general hydrography by combining two separate coverages: centerlines (network) and polygons (lakes and double-banked streams). The following is a list of the processing steps used to rejoin these coverages to create the general hydrography. The ARC commands used are capitalized and referenced in Environmental Systems Research Institute, Inc., 1989; the AMLS are available upon request from the USGS, Portland, Oregon:

a. Added a blank. PAT file to the network HUC coverages. (patlinks.aml)

b. Added a blank. AAT file to the bank HUC coverages. (aatbanks.aml)

c. Executed PULLITEMs on . AAT file for necessary Puget sound items.

d. Executed IDENTIFY with banks coverages to acquire county and quad names.

e. Both network and banks coverages were projected back to UTM (Zone 10) from Albers (albtoutm.aml).

f. The network and bank coverages were APPENDed once items were identical in each.

g. The coverages were tiled to $100 \mathrm{~K}$ quads by first creating 18 separate clipcovers for the Puget Sound Basin (makeindex.aml). Next, MAPJOIN was used to piece together the necessary HUC coverages for each of the quads, using the clipcovers as a quad boundary cookie cutter. (hydrojoin.aml, hydroquad.aml)

$h$. Once the quads were reconstructed the centerlines were put into separate coverages (quad.999) and then deleted.

i. Slight differences in map projections and index coverages from the PNW River Reach to Puget Sound Geographic Information System (PSGIS) projects meant additional editing was needed to ensure segments were in their correct quad.

j. Strname was added to the banks.aat file by hand editing and by nametrans. aml.

k. A frequency AML was used as a error check on items such as STRNAME, QUAD100, QUAD75 and COUNTY. (freq.aml)

1. As an additional check, the quads were plotted and compared to the NMD $100 \mathrm{~K}$ quad map sheets. (quadplot.aml) 


\section{References:}

Environmental Systems Research Institute, Inc., 1989, ARC/INFO command references: Redlands, California, Volume 2, Version 5.0.1, Appendix D.

Horn, C. R., 1986, River-reach file manual (Draft): U.S. Environmental Protection Agency, Washington, D.C., 50 p. [Available from U.S. Environmental Protection Agency, $401 \mathrm{M}$ St. SW, Washington, D.C. 20460]

U.S. Geological Survey, 1989, Digital line graphs from 1:100,000scale maps-Data users guide 2: Reston, Virginia, 88 p.

Additional notes:

Quadname abbreviations: Quadrangle name coverage name

$\begin{array}{ll}\text { Cape Flattery } & \text { hy.flat } \\ \text { Port Angeles } & \text { hy.pang } \\ \text { Roche Harbor } & \text { hy.roch } \\ \text { Bellingham } & \text { hy.bell } \\ \text { Port Townsend } & \text { hy.ptow } \\ \text { Seattle } & \text { hy.seat } \\ \text { Tacoma } & \text { hy.taco } \\ \text { Mount Baker } & \text { hy.mbak } \\ \text { Sauk River } & \text { hy.sauk } \\ \text { Skykomish River } & \text { hy.skyk } \\ \text { Snoqualmie Pass } & \text { hy.snoq } \\ \text { Mount Rainier } & \text { hy.rain } \\ \text { Robinson Mtn. } & \text { hy.robi } \\ \text { Twisp } & \text { hy.twis }\end{array}$

River Reach Network

DOCUMENTATION FOR DATA LAYERS: HYDRO"1-21". UTM, BANKS"1-21". ID) Numbers 1-21 are the PSGIS HUC's SOURCE REFERENCE: USGS-NMD 1:100,000-scale Digital Line Graphs MAP PROJECTION: UTM, ZONe 10

PRECISION: Single

TOLERANCES: Fuzzy $=.001$ Dangle $=1.0$

THEME: Puget Sound Hydrography (centerlines)

DESCRIPTION: Topological network coverages of hydrography, with centerlined double-banked streams, reservoirs and some lakes, tiled at USGS Hydrologic Units (17110001-17110021) for the Puget Sound Basin. Does not include Puget Sound shoreline. 
CONTACT PERSON/S: Mark Uhrich or Bruce Fisher

CONTACT INSTRUCTIONS: Uhrich 503-251-3292

Fisher 503-251-3228

ORGANIZATION: USGS -WRD

LOCATION DESCRIPTION: Puget Sound Basin covering

Longitude: $125^{\circ}-120^{\circ}$, Latitude: $46^{\circ} 30^{\prime \prime}-49^{\circ}$

$18 \mathrm{NMD} 100 \mathrm{~K}$ quads

RESOLUTION: $167 \mathrm{ft}(50.9 \mathrm{~m})$

SCALE : $1: 100,000$

ARCHIVE LOCATIONS: PSWQA; USGS-WRD; USEPA, Seattle

INFO ITEM DEFINITIONS FOR HYDRO"1-21".UTM.PAT or

BANKS"1-21". ID. PAT FILES:

COL ITEM NAME WDTH OPUT TYP N.DEC DEFINITION
17 MAJOR1 $\quad 6 \quad 6 \quad$ I $\quad$ - NMD feature classifier. Major1 $=50$ is combined hydrography category, Major1 $=170$ is transportation

23 MINOR1 $\quad 6 \quad 6 \quad$ I $\quad$ - NMD feature classifier. Minor1 $=412$ is stream, Minor1 $=999$ is artificial reach

29 MINOR2 $\quad 6 \quad 6 \quad$ I $\quad$ - NMD feature classifier. Minor2 $=610$ is ephemeral, Minor $2=$ 9999 is river mouth closure

$\begin{array}{llllll}35 & \text { MINOR3 } & 6 & 6 & \text { I } & \text { - NMD feature classifier. Used }\end{array}$ as a placer for some processing steps

41 HUC $8 \quad 8$ I - USGS Hydrologic Unit Code. Puget Sound codes $=$ $17110001-17110021$

INFO NAME DEFINITIONS FOR HYDRO"1-21".UTM.AAT Or

BANKS"1-21".ID.AAT FILES :

COL ITEM NAME WDTH OPUT TYP N.DEC DEFINITION

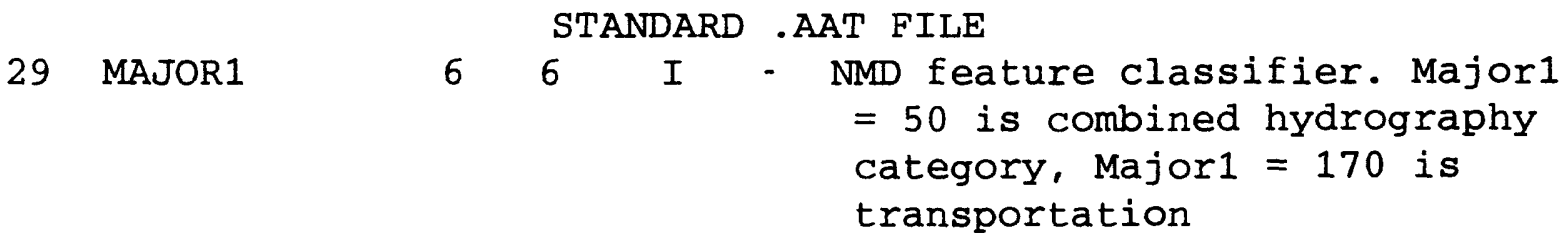




\begin{tabular}{|c|c|c|c|c|c|c|}
\hline 35 & MINOR1 & 6 & 6 & $I$ & - & $\begin{array}{l}\text { NMD feature classifier. Minor } 1 \\
=412 \text { is stream, Minor } 1=999 \\
\text { is artificial reach }\end{array}$ \\
\hline 41 & MINOR2 & 6 & 6 & $I$ & - & $\begin{array}{l}\text { NMD feature classifier. Minor2 } \\
=610 \text { is ephemeral, Minor } 2= \\
9999 \text { is river mouth closure }\end{array}$ \\
\hline 47 & MINOR3 & 6 & 6 & $I$ & - & $\begin{array}{l}\text { NMD feature classifier. Used } \\
\text { as a placer for some } \\
\text { processing steps }\end{array}$ \\
\hline 53 & HUC & 8 & 8 & $I$ & - & $\begin{array}{l}\text { USGS Hydrologic Unit Code. } \\
\text { Puget Sound codes }= \\
17110001-17110021\end{array}$ \\
\hline 61 & SEG & 4 & 4 & $I$ & - & $\begin{array}{l}\text { USEPA segment number. } \\
\text { HUC }+ \text { SEG = unique reach id }\end{array}$ \\
\hline 65 & RMI & 5 & 5 & $\mathrm{~N}$ & 2 & $\begin{array}{l}\text { River mile index calculated for } \\
\text { same numbered SEG reaches. Base } \\
\text { reach numbers begin with } 0.0\end{array}$ \\
\hline 70 & LEVEL & 2 & 2 & $I$ & - & $\begin{array}{l}\text { USEPA assigned stream level. } \\
\text { Tributary is one level higher } \\
\text { than mainstream. Uses reverse } \\
\text { Strahler order }\end{array}$ \\
\hline 72 & SEQNUM & 11 & 11 & $C$ & - & $\begin{array}{l}\text { USEPA hydrologic sequence } \\
\text { number. Most upstream reaches } \\
\text { have lowest numbers }\end{array}$ \\
\hline 83 & FLAGS & 5 & 5 & C & - & $\begin{array}{l}\text { USEPA item used for routing. } \\
\text { EX: Transport reaches }=1 \\
\text { shoreline }=0\end{array}$ \\
\hline 88 & STR-NAME & 30 & 30 & $\mathrm{C}$ & - & $\begin{array}{l}\text { Stream name from NMD } 100 \mathrm{~K} \\
\text { Digital Line Graphs or } \\
\text { USEPA 250K Trace files }\end{array}$ \\
\hline 118 & STATE & 4 & 4 & $\mathrm{C}$ & - & State reach falls within \\
\hline 122 & COUNTY & 15 & 15 & $\mathrm{C}$ & - & County reach falls within \\
\hline 137 & QUAD100 & 26 & 26 & C & - & $\begin{array}{l}\text { USGS } 100 \mathrm{~K} \text { quad reach falls } \\
\text { within }\end{array}$ \\
\hline 163 & QUAD75 & 25 & 25 & C & - & $\begin{array}{l}\text { USGS } 7.5 \text { min quad reach falls } \\
\text { within }\end{array}$ \\
\hline 188 & $\mathrm{RN}$ & 17 & 17 & $\mathrm{C}$ & - & $\mathrm{HUC}+\mathrm{SEG}+\mathrm{RMI}$ \\
\hline
\end{tabular}

COVERAGE NARRATIVE:

Abstract-In addition to the $100 \mathrm{~K}$ quad general hydrography layer, the Puget Sound GIS project also includes PNW River Reach data layers, in which the double-banked streams and reservoirs have been centerlined for routing purposes. These data layers, also referred to as network coverages, have had additional editing performed to meet the criteria of the PSWQA. The ARC $\mathrm{log}$ files of each coverage list specific ARC commands used and additional notes. 
Processing steps- The double-banked streams, reservoirs, and most lakes are put into separate "banks" coverages by the PNW River Reach project. The double-banked coverages were rejoined with the centerlined coverages for the general PSGIS hydrography layer. The coverages, acquired in April, 1990 from the PNW River Reach study were not their final product. A later revision of the River Reach Files removed the nodes created at political boundaries and added to every reach the second most predominant STATE, COUNTY, QUAD100 and QUAD75 name. These items are not included. The ARC command: PULLITEMS was used on each coverage to attain the desired PSGIS attributes.

The editing performed on the network coverages involved correcting USGS-NMD minor code attributes such as minorl = 103 for glaciers. Differences in minor 1 codes for shoreline existed in each of the coverages. Some lakes were given a code of 200, others 421. Many of the minor1 codes of 421 were recalculated to 200 to standardize the attributes. Other discrepancies were found with the River Reach data. For instance, some inland lakes were put into the banks coverages and deleted, some were put into the banks and not deleted from the network coverage. Some lakes were kept in the network coverage and not put into the banks, and still others were deleted entirely and not put into the banks. Some network coverages routed up the side of an inland lake, others used a centerline. of the network coverages routing up inland lake shorelines, some were given minorl codes $=999$, which should only have been given to artificial centerlines. Most of these problems were corrected. Check the coverage ARC log files for detailed information. The Puget Sound shoreline was put into the Sound and Embayment PSGIS data layers and deleted from the centerlined coverages. No figure of the network data was included since at a scale of $1: 2,000,000$ the plot was not significantly different than the general hydrography plot.

References:

Horn, C. R., 1986, River-reach file manual (Draft): U.S. Environmental Protection Agency, Washington, D.C., 50 p. [Available from U.S. Environmental Protection Agency, 401 M St. SW, Washington, D.C. 20460].

U.S. Geological Survey, 1989, Digital line graphs from 1:100,000-scale maps-Data users guide 2: Reston, Virginia, 88 p. 


\section{Watershed Boundaries}

\section{U.S. Geological Survey Hydrologic Unit Codes}

DOCUMENTATION FOR DATA LAYER: PS_HUC

SOURCE REFERENCE: USGS-NMD 1:100,000-scale Digital Line Graphs MAP PROJECTION: UTM, Zone 10

PRECISION: Single

TOLERANC̣ES: Fuzzy $=.001$ Dangle $=1.0$

THEME: Puget Sound Hydrography, Basin Boundary

DESCRIPTION: Basin Boundary for the Puget Sound watershed

CONTACT PERSON/S: Mark Uhrich or Bruce Fisher

CONTACT INSTRUCTIONS: Uhrich 503-251-3292

Fisher 503-251-3228

ORGANIZATION : USGS -WRD

LOCATION DESCRIPTION: Puget Sound Basin

Longitude: $125^{\circ}-120^{\circ}$, Latitude: $46^{\circ} 30^{\prime \prime}-49^{\circ}$

USGS Hydrologic Unit 171100

RESOLUTION: $167 \mathrm{ft}(50.9 \mathrm{~m})$

SCALE : $1: 100,000$

ARCHIVE LOCATIONS: PSWQA; Washington DNR,

Division of Aquatic Resources

ITEM DEFINITIONS FOR PS_HUC.PAT FILE:

COL ITEM NAME WDTH OPUT TYP N.DEC DEFINITION

17 HUC

STANDARD . PAT FILE (POIYgON)

$8 \quad 8$ I 0 USGS-WRD Hydrologic Unit Code number

INFO NAME DEFINITIONS FOR PS_HUC.AAT FILE:

$$
\text { STANDARD . AAT FILE }
$$

COVERAGE NARRATIVE:

Abstract - The Puget Sound Basin HUC coverage was used to reference other layers to it, such as the hydrography and water Resource Inventory Areas (WRIA). It consists of the Regional/Subregional USGS Hydrologic Unit Code 1711 and 21 cataloging units.

Processing steps - The $100 \mathrm{~K}$ HUC watershed boundary data layer was obtained from the PNW River Reach project

(B.J. Fisher, U.S. Geological Survey, oral commun., 1992). The HUC coverage was projected from Albers Equal Area to UTM. 
All of the subbasins that existed within the Puget Sound HUC (1711) were selected and a subset coverage was created (ps_huc).

References :

U.S. Geological Survey, 1989, Digital line graphs from 1:100,000-scale maps-Data users guide 2: Reston, Virginia, 88 p.

Horn, C. R., 1986, River-reach file manual (Draft): U.S. Environmental Protection Agency, Washington, D.C., 50 p. [Available from U.S. Environmental Protection Agency, 401 M St. SW, Washington, D.C. 20460].

\section{Puget Sound Basin}

DOCUMENTATION FOR DATA LAYER: PS_BASIN

SOURCE REFERENCE: USGS-NMD 1:100,000-scale Digital Line Graphs MAP PROJECTION: UTM, Zone 10

PRECISION: Single

TOLERANCES: Fuzzy $=.001$ Dangle $=1.0$

THEME: Puget Sound Hydrography, Basin Boundary

DESCRIPTION: Basin Boundary for the Puget Sound watershed

CONTACT PERSON/S: Mark Uhrich or Bruce Fisher

CONTACT INSTRUCTIONS: Uhrich 503-251-3292

Fisher 503-251-3228

ORGANIZATION : USGS-WRD

LOCATION DESCRIPTION: Puget Sound Basin

Longitude: $125^{\circ}-120^{\circ}$, Latitude: $46^{\circ} 30^{\prime \prime}-49^{\circ}$

USGS Hydrologic Unit 171100

RESOLUTION: $167 \mathrm{ft}(50.9 \mathrm{~m})$

SCALE: $1: 100,000$

ARCHIVE LOCATIONS: PSWQA; Washington DNR, Division of Aquatic Resources

INFO ITEM DEFINITIONS FOR PS_BASIN.PAT FILE:

STANDARD . PAT FILE (POIYgOn)

INFO NAME DEFINITIONS FOR PS_BASIN.AAT FILE:

$$
\text { STANDARD . AAT FILE }
$$

COVERAGE NARRATIVE:

Abstract - The Puget Sound Basin coverage was created as a reference layer and clip coverage. It consists of basins with the Hydrologic Unit Code 1711, (Region=17, Subregion=11) . 
Processing steps - The 100K HUC watershed boundary data layer was obtained from the PNW River Reach project. The HUC coverage was projected from Albers Equal Area to UTM. All of the subbasins that were within the Puget Sound HUC (1711) were selected and a subset coverage was created (PS_HUC). To create the Basin Boundary

coverage, all of the HUC boundaries were eliminated below the 1711 identifier. Twenty-one subbasins make up the 1711 Puget Sound Basin (17110001-17110021). These were aggregated using the ARC command DISSOLVE on the value 1711 for the item HUC of the ps_huc data layer.

\section{References :}

Horn, C. R., 1986, River-reach file manual (Draft): U.S. Environmental Protection Agency, Washington, D.C., 50 p. [Available from U.S. Environmental Protection Agency, 401 M St. SW, Washington, D.C. 20460].

U.S. Geological Survey, 1989, Digital line graphs from 1:100,000-scale maps-Data users guide 2: Reston, Virginia, 88 p.

\section{Water Resource Inventory Areas}

DOCUMENTATION FOR DATA LAYER: PS_WRIA

SOURCE REFERENCE: Washington DNR, Division of Aquatic Resources MAP PROJECTION: UTM, Zone 10

PRECISION: Single

TOLERANCES: Fuzzy $=.001$ Dangle $=1.0$

THEME: Puget Sound, WRIA

DESCRIPTION: The Washington DNR has delimited watershed areas for administrative and management purposes. This theme is provided as an index and reference layer for the PSGIS.

CONTACT PERSON/S: Elizabeth Lanzer(1), or

Elizabeth Thompson (2)

CONTACT INSTRUCTIONS: (1) Lanzer 360-902-1074

(2) Thompson 360-902-1224

ORGANIZATION: (1) Washington DNR, Division of Aquatic Resources

(2) Washington DNR, Division of Forest Practices LOCATION DESCRIPTION: Puget Sound Basin

Longitude: $125^{\circ}-120^{\circ}$, Latitude: $46^{\circ} 30^{\prime \prime}-49^{\circ}$

RESOLUTION: $167 \mathrm{ft}(50.9 \mathrm{~m})$

SCALE: $1: 100,000$

ARCHIVE LOCATIONS: PSWQA; Washington DNR, Division of Aquatic Resources 
INFO ITEM DEFINITIONS FOR PS_WRIA.PAT FILE:

COL ITEM NAME WDTH OPUT TYP N.DEC DEFINITION

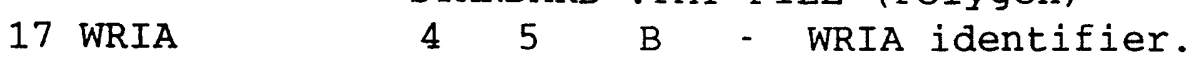

INFO NAME DEFINITIONS FOR PS_WRIA.AAT FILE:

$$
\text { STANDARD .AAT FILE }
$$

COVERAGE NARRATIVE:

Abstract - The Washington DNR has delimited watershed boundaries for management purposes throughout the state. These WRIA's were obtained from Washington DNR, Division of Aquatic Resources.

Processing steps - An ARC/INFO format coverage for the WRIA's was obtained from the Washington DNR, Aquatic Resources. The coverage was projected from State Plane south zone (5626) to UTM, Zone 10. The WRIA coverage was reduced from a statewide coverage to one within the extent of the Puget Sound Basin.

References :

Washington Department of Ecology, 1986, Water-resources inventory areas subbasins, Washington Administrative Code, Title 173-500990: Olympia, Washington, p. 490-492. 


\section{Political Boundaries and Public Land Survey System (PLSS)}

\section{Boundary Data Layer}

DOCUMENTATION FOR DATA LAYER: Name given as 100K "Quadname", datalayers in the BOUND directory, see Table 2 for quadname abbreviations SOURCE REFERENCE: USGS-NMD 1:100,000-scale Digital Line Graphs MAP PROJTECTION: UTM, Zone 10

PRECISION: Single TOLERANCES: Fuzzy $=.001$ Dangle $=1.0$

THEME: Puget Sound Political Boundaries

DESCRIPTION: Standard USGS-NMD Boundary DLG data which includes data for Federal and Tribal lands, state and County FIPS codes.

CONTACT PERSON/S: Mark Uhrich

CONTACT INSTRUCTIONS: Uhrich 503-251-3292

ORGANIZATION: USGS - WRD

LOCATION DESCRIPTION: Puget Sound Basin

Longitude: $125^{\circ}-120^{\circ}$, Latitude: $46^{\circ} 30^{\prime \prime}-49^{\circ}$

RESOLUTION: $167 \mathrm{ft}(50.9 \mathrm{~m})$

SCALE: $1: 100,000$

ARCHIVE LOCATION: PSWQA

INFO ITEM DEFINITIONS FOR BOUND/"QUADNAME".PAT FILE:

COL ITEM NAME WDTH OPUT TYP N.DEC DEFINITION

17 MAJOR 1

23 MINOR1

29 MAJOR2

35 MINOR2

41 MAJOR3

47 MINOR3

53 MAJOR4

59 MINOR4

\section{STANDARD . PAT FILE (Polygon)}

66 I - NMD feature classifier.

$6 \quad 6$ I - NMD feature classifier.

$6 \quad 6$ I - NMD feature classifier.

$6 \quad 6$ I - NMD feature classifier.

$6 \quad 6 \quad I$ - NMD feature classifier.

66 I - NMD feature classifier.

$6 \quad 6$ I - NMD feature classifier.

$6 \quad 6$ I - NMD feature classifier. 
INFO NAME DEFINITIONS FOR BOUND/"QUADNAME". AAT FILE:

COL ITEM NAME WDTH OPUT TYP N.DEC DEFINITION

\begin{tabular}{lllllll} 
& \multicolumn{6}{c}{ STANDARD } \\
29 & MAJOR1 & 6 & 6 & I & - & NMD FILE \\
35 & MINOR1 & 6 & 6 & I & - & NMD feature classifier. \\
41 & MAJOR2 & 6 & 6 & I & - & NMD feature classifier. \\
47 & MINOR2 & 6 & 6 & I & - & NMD feature classifier. \\
53 & MAJOR3 & 6 & 6 & I & - & NMD feature classifier. \\
59 & MINOR3 & 6 & 6 & I & - & NMD feature classifier. \\
65 & MAJOR4 & 6 & 6 & I & - & NMD feature classifier. \\
71 & MINOR4 & 6 & 6 & I & - & NMD feature classifier.
\end{tabular}

COVERAGE NARRATIVE:

Abstract - The Boundaries data layer is from the USGS-NMD, 1:100,000 scale Digital Line Graphs. Information contained in boundary DLG's includes county, Federal, and Tribal boundaries and others.

Processing steps - The DLG's were converted to ARC/INFO format with the DLGARC command (Environmental Systems Research Institute, Inc., 1989). The DLGs come in four pieces for each half (east and west) of a $100 \mathrm{~K}$ quadrangle sheet. The pieces were paneled together as were the east and west half of each coverage. Finally, all of the quadrangle sheet coverages were edgematched and appended into a composite, sound-wide boundary data layer. Using the county FIPS codes contained in the Major and Minor pairs, (USGS,1989), a Counties coverage was created using the DISSOLVE command on the FIPS code.

References:

Environmental Systems Research Institute, Inc., 1989, ARC/INFO command references: Redlands, California, Volume 2, Version 5.0.1, Appendix D.

U.S. Geological Survey, 1989, Digital line graphs from 1:100,000scale maps-Data users guide 2: Reston, Virginia, 88 p. 


\section{Public Land Survey System Data Layer}

DOCUMENTATION FOR DATA LAYER: Name given as 100K "Quadname", datalayers in the PISS directory, see Table 2 for quadname abbreviations SOURCE REFERENCE: USGS-NMD 1:100,000-scale Digital Line Graphs MAP PROJECTION: UTM, ZOne 10

PRECISION: Single

TOLERANÇES: Fuzzy $=.001$ Dangle $=1.0$

THEME: Puget Sound Public Land Survey

DESCRIPTION: Standard USGS-NMD PLSS DLG data which includes data for Township, Range and Section, and surveyed benchmarks.

CONTACT PERSON/S: Mark Uhrich

CONTACT INSTRUCTIONS: Uhrich 503-251-3292

ORGANIZATION: USGS-WRD

LOCATION DESCRIPTION: Puget Sound Basin

Longitude: $125^{\circ}-120^{\circ}$, Latitude: $46^{\circ} 30^{\prime \prime}-49^{\circ}$

RESOLUTION: $167 \mathrm{ft}(50.9 \mathrm{~m})$

SCALE : $1: 100,000$

ARCHIVE LOCATION: PSWQA

INFO ITEM DEFINITIONS FOR PLSS/"QUADNAME". PAT FILE:

COL ITEM NAME WDTH OPUT TYP N.DEC DEFINITION

STANDARD . PAT FILE (POlygon)

17 MAJOR1

$6 \quad 6$ I - NMD feature classifier.

23 MINOR1

29 MAJOR2

35 MINOR2

41 MAJOR3

47 MINOR3

53 MAJOR4

59 MINOR4

$\begin{array}{lllll}6 & 6 & \text { I } & \text { - } & \text { NMD feature classifier. } \\ 6 & 6 & \text { I } & \text { - } & \text { NMD feature classifier. } \\ 6 & 6 & \text { I } & \text { - } \text { NMD feature classifier. } \\ 6 & 6 & \text { I } & \text { - } & \text { NMD feature classifier. } \\ 6 & 6 & \text { I } & \text { - } & \text { NMD feature classifier. } \\ 6 & 6 & \text { I } & \text { - } & \text { NMD feature classifier. } \\ 6 & 6 & \text { I } & - & \text { NMD feature classifier. }\end{array}$

INFO NAME DEFINITIONS FOR PLSS/"QUADNAME".AAT FILE:

COL ITEM NAME WDTH OPUT TYP N.DEC DEFINITION

29 MAJOR1

35 MINOR1

41 MAJOR2

47 MINOR2

53 MAJOR3

59 MINOR3

65 MAJOR4

71 MINOR4

\section{STANDARD . AAT FILE}

$\begin{array}{lllll}6 & \text { I } & - & - & \text { NMD feature classifier. } \\ 6 & 6 & \text { I } & - & \text { NMD feature classifier. } \\ 6 & 6 & \text { I } & - & \text { NMD feature classifier. } \\ 6 & 6 & \text { I } & - & \text { NMD feature classifier. } \\ 6 & 6 & \text { I } & - & \text { NMD feature classifier. } \\ 6 & 6 & \text { I } & - & \text { NMD feature classifier. } \\ 6 & 6 & \text { I } & - & \text { NMD feature classifier. } \\ 6 & 6 & \text { I } & - & \text { NMD feature classifier. }\end{array}$


Abstract - The PLSS data layer was developed from the USGS-NMD, 1:100,000 scale Digital Line Graphs. Information contained in PLSS DLG's includes township and range section lines, benchmark monument locations, surveyed section corners, subdivision corners, ownership corners, etc.

Processing steps - The DLG's were converted to ARC/INFO format with the DLGARC command (ESRI, 1989). The DLG's come in four pieces for each half (east and west) of a $100 \mathrm{~K}$ quad sheet. The pieces were paneled together as were the east and west half of each data layer. The PLSS data were edgematched, but were not paneled into a soundwide data layer. There are two separate data layers for each $100 \mathrm{~K}$ quad that contain line and point topology, respectively. The line data layer represents the section lines, the point data layer represents the different corners. No figure of this data was included in this report as the plotting scale of $1: 2,000,000$ used for the entire Puget Sound Basin would not provide sufficient resolution to determine the individual section lines.

\section{References:}

U.S. Geological Survey, 1989, Digital line graphs from 1:100,000scale maps-Data users guide 2: Reston, Virginia, $88 \mathrm{p}$.

Environmental Systems Research Institute, Inc., 1989, ARC/INFO command references: Redlands, California, Volume 2, Version 5.0.1. Appendix D. 


\section{Geographic Names}

DOCUMENTATION FOR DATA LAYER: WAGAZ_PS

SOURCE REFERENCE: USGS-NMD

Geographic Names Information System (GNIS)

(acquired from Washington Department of Fish \& Wildlife)

MAP PROJECTION: UTM, Zone 10

PRECISION: Single

TOLERANCES: Fuzzy $=.001$ Dangle $=1.0$

THEME: Puget Sound Geographic Names

DESCRIPTION: The Puget Sound Geographic Names was extracted from

the USGS-NMD Geographic Names Information System

CONTACT PERSON/S: 1. Mark Uhrich(1) or Shelly Snyder(2)

CONTACT INSTRUCTIONS: 1. Uhrich 503-251-3292

2. Snyder 360-902-2983

ORGANIZATION: 1. USGS 2.Washington Department of Fish \& Wildiife LOCATION DESCRIPTION: Puget Sound Geographic Names

Longitude: $125^{\circ}-122^{\circ}$, Latitude: $47^{\circ}-49^{\circ}$

RESOLUTION: $167 \mathrm{ft}(50.9 \mathrm{~m})$

SCALE : $1: 100,000$

ARCHIVE LOCATIONS: PSWQA; Washington Department of Fish \& Wildlife

INFO ITEM DEFINITIONS FOR WAGAZ_PS.PAT FILE:

COL ITEM NAME WDTH OPUT TYP N.DEC DEFINITION

17 PTNAME

64 PT.NAME

111 FCLASS

121 F.CLASS

131 SCCODES

143 GCOORD

164 ELEV

170 SCOORD

186 GNISMC

$$
\text { STANDARD . PAT FILE (Point) }
$$

$\begin{array}{llll}47 & 47 & \mathrm{C} & \text { - Place name (Upper Case) }\end{array}$

4747 C - Place name (lower case)

1010 C - Feature class (Upper Case)

$1010 \mathrm{C}$ - Feature class (lower case)

1212 C - State and County FIPS codes

1616 C - Geographic coordinate in

latitude/longitude with

direction given,

Ex: (473000N12230000W)

$5 \quad 5 \quad$ C $\quad$ U.S. Board on Geographic Names decision date

66 I - Elevation in feet if published on USGS topographic map

1616 C - Source coordinate for linear feature, (stream, canyon), in same GCOORD format

2020 C - GNIS Map Code, 4 digit number refers to $7.5^{\prime}$ USGS map 


\begin{tabular}{|c|c|c|c|c|c|c|}
\hline 206 & QUADCODE $\$ 7$ & 7 & I & - & 7 & $\begin{array}{l}\text { digit number identifies } \\
\text { position of } 7.5^{\prime} \text { USGS map. }\end{array}$ \\
\hline 213 & QUADNAME & 23 & 23 & $\mathrm{C}$ & - & USGS $7.5^{\prime}$ map name \\
\hline 236 & Q100KCODE\$ & 5 & 5 & C & - & $\begin{array}{l}\text { Washington DNR mapsheet } \\
100 \mathrm{k} \text { quad belongs }\end{array}$ \\
\hline 241 & Q250KCODE\$ & 5 & 5 & C & - & $\begin{array}{l}\text { Washington DNR mapsheet } \\
250 \mathrm{~K} \text { quad belongs }\end{array}$ \\
\hline 246 & DNRCODE $\$$ & 4 & 4 & $I$ & - & $\begin{array}{l}\text { Washington DNR naming } \\
\text { convention to locate } \\
\text { quads using row and columns }\end{array}$ \\
\hline 250 & QUADCODE & 4 & 7 & B & - & Same as QUADCODE $\$$, but binary \\
\hline 254 & ITEM.NO & 7 & 7 & I & - & $=$ WAGAZ_PS-ID, has comma's \\
\hline 261 & $\mathrm{X}-\mathrm{COORD}$ & 4 & 12 & $\mathrm{~F}$ & 3 & $\mathrm{X}$ coordinate in UTM, Zone 10 \\
\hline 265 & $Y-C O O R D$ & 4 & 12 & $F$ & 3 & Y coordinate in UTM, Zone 10 \\
\hline \multicolumn{7}{|c|}{ **REDEF INED ITEMS ** } \\
\hline 64 & PRINT.NAME & 30 & 30 & C & - & $\begin{array}{l}\text { Same as PT.NAME with less } \\
\text { character spaces }\end{array}$ \\
\hline 143 & LAT & 7 & . & 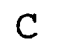 & 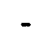 & Separate latitude from GCOORD \\
\hline 150 & LON & 8 & 8 & C & - & Separate longitude from GCOORD \\
\hline
\end{tabular}

COVERAGE NARRATIVE:

Abstract - The Geographic Names data layer was obtained from Washington Department of Fish \& Wildlife. It is a point data layer developed from the USGS-NMD GNIS file for Washington. The point coverage was clipped to match the extent of the Puget Sound Basin.

Processing steps - The point data layer was projected from Washington state plane, south zone (5626), to UTM, Zone 10 coordinates. The original point coverage (WAGAZ) covered the entire state. The projected point data layer was clipped with the Puget Sound Basin outline to produce a GNIS coverage for the PSGIS (PS_WAGAZ). No attributes were altered from the data acquired from Washington Department of Fish \& Wildlife. 


\section{APPENDIX B}

\section{Data-Layer Dictionary of the Puget Sound Environmental Atlas}

The Puget Sound Environmental Atlas (PSEA) data existed in digital form as Intergraph design files archived with the Army Corps of Engineers in Seattle, Washington. The Intergraph files were obtained and converted to Drawing Interchange Format (DXF) files by the Bonneville Power Administration in Portland, Oregon. DXF files are an Autocad file format that can be brought into ARC/ INFO. See the Conversion and Registration sections of the PSEA Data-Layer Description for additional information. The Puget Sound Environmental Atlas DXF files contain up to 63 layers (or 63 Intergraph Design File levels) of data. The PSEA was divided into 12 regions with border overlap occurring between all regions (Evans-Hamilton, Inc., and D.R. Systems, Inc., 1987). Some of the DXF layers contain data from only one resource, others contain data from several composited resources. All of the DXF file layers were converted to ARC/INFO format in one composite coverage for each of the 12 regions and registered to real world coordinates.

The converted data accurately matched the cartographic representation in the PSEA. An item in the composite data layer called DXF-LAYER could be used to RESELECT a desired layer. Appendixes I-III in "An Analysis of The Puget Sound Environmental Atlas," (Environmental Systems Research Institute, Inc., 1988) contain information on which PSEA resources are within which Intergraph design file level. The design file level and DXF layer are the same in the converted data. A number of processing steps were needed to create a topologically correct and attributed data set.

Separate coverages were created for each individual species or resource, for each PSEA region. Final editing assured topologically correct data and each species/resource was attributed with a unique - ID number to assist in compositing and attributing the final species/resource data layer. Each of the PSEA regional species/ resource data layers were then paneled together with the UNION command and DISSOLVED on the unique -ID creating a sound-wide data layer for each species or resource. Appending each of the 12 regional species/resource data layers into a sound-wide species/ resource data layer was now possible and eliminated duplication of the overlap areas occurring along the 12 regional boundaries. Based on the unique -ID's of the unioned composite, the final attributes, such as the species presence/absence flags, were populated. 


\section{Reference:}

Evans-Hamilton, Inc., and D.R. Systems, Inc., 1987, Puget Sound environmental atlas-Volumes I and II: Seattle, Washington, U.S. Environmental Protection Agency, Puget Sound water Quality Authority, and U.S. Army Corps of Engineers.

\section{Sea Bird Nesting Areas}

DOCUMENTATION FOR DATA LAYER: BIRD SOURCE REFERENCE: Puget Sound Environmental Atlas MAP PROJECTION: UTM, Zone 10

PRECISION: Single TOLERANCES: FuzzY $=.001$ Dangle $=1.0$

THEME: Puget Sound Sea Bird Nesting sites

DESCRIPTION: Sea bird nesting sites as small single polygons or linear polygonal features along a cliff or beach rookery. Attributed by species.

CONTACT PERSON/S: Mark Uhrich

CONTACT INSTRUCTIONS: Uhrich: 503-251-3292

ORGANIZATION: U.S. Geological Survey (USGS) Water Resources Division (WRD)

LOCATION DESCRIPTION: Puget Sound Basin

Longitude: $125^{\circ}-120^{\circ}$, Latitude: $46^{\circ} 30-49^{\circ}$

RESOLUTION: $167 \mathrm{ft}(50.9 \mathrm{~m})$

SCALE : $1: 100,000$

ARCHIVE LOCATION: Puget Sound Water Quality Authority (PSWQA); Washington Department of Natural Resources, Division of Aquatic Resources 
INFO ITEM DEFINITIONS FOR BIRD. PAT FILE:

COLITEM NAMEWDTH OPUT TYP N.DEC DEFINITION STANDARD . PAT FILE (POlygon)

14 AUKLET

1

1

15 D_CORMORANT

11

16 GUILLEMOT

17 GULL

$1 \quad 1 \quad I \quad-$

18 OYSTERCATCHER 1 1 I

11

I

$\sqrt{20}$

19 PUFFIN

111

20 P_CORMORANT

11

11

21 TERN
$11 I$
- Rhinoceros auklet. Presence/Absence flag ( $0=$ absent, 1 = present)

Double-crested cormorant. Presence/Absence flag $(0=$ absent, 1 = present)

Pigeon guillemot. Presence/Absence flag $(0=$ absent, 1 = present)

Glaucous-winged gull. Presence/Absence flag $(0=$ absent, 1 = present)

Black oystercatcher. Presence/Absence flag $(0=$ absent, 1 = present)

Tufted puffin. Presence/ Absence flag

$(0=$ absent, 1 = present $)$

Pelagic cormorant. Presence/Absence flag $(0=$ absent, 1 = present)

Arctic tern. Presence/Absence

flag $(0=$ absent, $1=$ present $)$

INFO ITEM DEFINITIONS FOR BIRD.AAT FILE:

STANDARD . AAT FILE 
Abstract - The PSEA contains compiled information on the location of seabird nesting sites in the Puget sound. The Seabird data layer in the Puget Sound GIS (Geographic Information System) is a reproduction of the information presented in the atlas in digital form, with associated database files which store attribute information.

Processing steps- The data layer extraction section in the main text contains the information on processing the sea bird symbols. Each species data layer from the 12 PSEA regions were composited together with the UNION command. These separate sea bird data layers were later composited, also using the UNION command, and formed the Seabird data layer (BIRD). Each sea bird species was given a unique identifier (the INFO COVERAGE-ID). These - ID numbers are listed in the table below. The unioned species data layers were given the naming convention; SPECIES_NAME.UN, e.g., AUKLET, (UN= UNIONED) .

PSEA Data Unique Feature Identification Numbers

(From INFO item SPECIES_NAME.UN-ID) :

Species ID\# Definition

$\begin{array}{lll}\text { AUKLET } & 1 & \text { Rhinoceros auklet } \\ \text { D_CORM } & 2 & \text { Double-crested cormorant } \\ \text { GUILLEMOT } & 3 & \text { Pigeon guillemot } \\ \text { GULL } & 4 & \text { Glaucous-winged gull } \\ \text { OYSTERCAT } & 5 & \text { Black oystercatcher } \\ \text { PUFFIN } & 6 & \text { Tufted puffin } \\ \text { P_CORM } & 7 & \text { Pelagic cormorant } \\ \text { TERN } & 8 & \text { Arctic tern }\end{array}$

A separate data layer was created for each species in the seabird nesting area resource-layer (BIRD). An example INFO Polygon Attribute Table (.PAT) for these unique data layers follows, the term SPECIES would be replaced by the name of the specific sea bird, e.g., P_CORM:

\begin{tabular}{lllllll}
\multicolumn{1}{c}{ COLITEM NAMEWDTH OPUT TYP N.DEC DEFINITION } \\
1 & AREA & 4 & 12 & $\mathrm{~F}$ & 3 & $\begin{array}{l}\text { Area of polygon in square } \\
\text { meters }\end{array}$ \\
5 & PERIMETER & 4 & 12 & $\mathrm{~F}$ & 3 & $\begin{array}{l}\text { Perimeter of polygon in meters } \\
9\end{array}$ \\
SPECIES\# & 4 & 5 & $\mathrm{~B}$ & - & Internal feature number \\
13 & SPECIES-ID & 4 & 5 & $\mathrm{~B}$ & - & User-assigned feature number \\
17 & SPECIES.UN-ID & 4 & 5 & $\mathrm{~B}$ & - & Unique species number
\end{tabular}




\section{Near-Shore Habitat}

DOCUMENTATION FOR DATA LAYER: HABITAT

SOURCE REFERENCE: Puget Sound Environmental Atlas

MAP PROJECTION: UTM, Zone 10

PRECISION: Single

TOLERANCES: Fuzzy $=.001$ Dangle $=1.0$

THEME: Puget Sound kelp and eelgrass features

DESCRIPTION: The scope of this project allowed only the conversion of two of the Habitat features from the PSEA: Kelp and Eelgrass.

CONTACT PERSON/S: Mark Uhrich

CONTACT INSTRUCTIONS: Uhrich: 503-251-3292

ORGANIZATION : USGS-WRD

LOCATION DESCRIPTION: Puget Sound Basin

Longitude: $125^{\circ}-120^{\circ}$, Latitude: $46^{\circ} 30-49^{\circ}$

RESOLUTION: $167 \mathrm{ft}(50.9 \mathrm{~m})$

SCALE : $1: 100,000$

ARCHIVE LOCATION: PSWQA; Washington DNR, Division of Aquatic Resources

INFO ITEM DEFINITIONS FOR HABITAT.PAT FILE (Output $=18$ ): COLITEM NAMEWDTH OPUT TYP N.DEC DEFINITION STANDARD .PAT FILE (POlygOn)

14 KELP $\quad 1 \quad 1 \quad I \quad-$ Kelp. Presence/Absence flag ( 0 =absent, 1 = present $)$

15 EELGRASS $\quad 1 \quad 1 \quad I \quad$ - Eelgrass. Presence/Absence flag $(0=$ absent, 1 = present $)$

INFO ITEM DEFINITIONS FOR HABITAT.AAT FILE:

STANDARD . AAT FILE

COVERAGE NARRATIVE:

Abstract - The PSEA contains compiled information on the location of habitat resources in the Puget Sound. The Habitat data layer in the Puget Sound GIS is a reproduction of the information presented in the atlas in digital form, with associated database files which store attribute information. 
Processing steps - The DXF files containing the data on kelp and eelgrass were the Extra files. As explained in the DXF Conversion and Registration sections of the main text, the Extra files were often registered inaccurately and did not have any reference feature to match the Base DXF file. In these cases the kelp and eelgrass data were registered manually, by visually fitting the reference features as close as possible.

Kelp and eelgrass were the only two data layers converted and were represented in the PSEA and DXF files as polygons. The delimiting polygon was selected in ARCEDIT and the PUT command was used to place the feature into a eelgrass or kelp data layer for final editing and attribution. Each eelgrass/kelp data layer from the 12 PSEA regions was composited together with the UNION command. These separate eelgrass/kelp data layers were later composited, also using the UNION command, and formed the Near-Shore Habitat data layer (HABITAT). Each habitat species or resource was given a unique identifier (the INFO COVERAGE-ID). These - ID numbers are listed below. The unioned species data layers were given the naming convention; SPECIES_NAME.UN, e.g., EELGRASS, (UN= UNIONED) .

PSEA Data Unique Feature Identification Numbers

(From INFO item SPECIES_NAME.UN-ID) :

Name ID\# Definition

$\begin{array}{lll}\text { EELGRASS } & 9 & \text { Eelgrass } \\ \text { HMA } & 10 & \text { Habitat Management Area } \\ \text { KELP } & 11 & \text { Kelp } \\ \text { NES } & 12 & \text { National Estuarine Sanctuary } \\ \text { NP } & 13 & \text { Nature Preserve } \\ \text { NWR } & 14 & \text { National Wildlife Refuge }\end{array}$

The INFO Polygon Attribute Table (.PAT) from the separate data layers created for the two species in the HABITAT resource-layer is given below. The term SPECIES is generic for either EELGRASS or KELP :

COLITEM NAMEWDTH OPUT TYP N.DEC DEFINITION

\begin{tabular}{|c|c|c|c|c|c|c|}
\hline 1 & AREA & 4 & 12 & $\mathrm{~F}$ & 3 & $\begin{array}{l}\text { Area of polygon in square } \\
\text { meters }\end{array}$ \\
\hline 9 & PERIMETER & 4 & 12 & $\mathrm{~F}$ & 3 & Perimeter of polygon in -meters \\
\hline 17 & SPECIES\# & 4 & 5 & $\mathrm{~B}$ & - & Internal feature number \\
\hline 1 & SPECIES - ID & 4 & 5 & B & - & User-assigned feature number \\
\hline 5 & SPECIES.UN-ID & 4 & 5 & B & - & Unique species number \\
\hline 29 & SPECIES & 1 & 1 & $I$ & - & Presence/Absence flag \\
\hline
\end{tabular}




\section{Marine Mammal}

DOCUMENTATION FOR DATA LAYER: MAMMAL

SOURCE REFERENCE: Puget Sound Environmental Atlas

MAP PROJECTION: UTM, ZONe 10

PRECISION: Single

TOLERANCES: Fuzzy $=.001$ Dangle $=1.0$

THEME: Marine Mammal Haulouts and sightings

DESCRIPTION: Marine Mammal haulout areas and frequent sighting locations

CONTACT PERSON/S: Mark Uhrich

CONTACT INSTRUCTIONS: Uhrich 503-251-3292

ORGANIZATION: USGS-WRD

LOCATION DESCRIPTION: Puget Sound Basin

Longitude: $125^{\circ}-120^{\circ}$, Latitude: $46^{\circ} 30-49^{\circ}$

RESOLUTION: $167 \mathrm{ft}(50.9 \mathrm{~m})$

SCALE : $1: 100,000$

ARCHIVE LOCATION: PSWQA; Washington DNR,

Division of Aquatic Resources

INFO ITEM DEFINITIONS FOR MAMMAL. PAT FILE:

COLITEM NAMEWDTH OPUT TYP N.DEC DEFINITION

\begin{tabular}{|c|c|c|c|c|c|}
\hline & & & JDARD &. $\mathrm{PAT}$ & FILE (Polygon) \\
\hline 14 & C_SEALION & 1 & 1 & I & $\begin{array}{l}\text { California sea lion. } \\
\text { Presence/Absence flag } \quad(0= \\
\text { absent, } 1=\text { present })\end{array}$ \\
\hline & DALL_PORP & 1 & 1 & I & $\begin{array}{l}\text { Dall's porpoise. } \\
\text { Presence/Absence flag }(0= \\
\text { absent, } 1=\text { present })\end{array}$ \\
\hline & HARB_PORP & 1 & 1 & I & $\begin{array}{l}\text { Harbor porpoise. } \\
\text { Presence/Absence flag }(0= \\
\text { absent, } 1=\text { present })\end{array}$ \\
\hline & HARB_SEAL & 1 & 1 & I & $\begin{array}{l}\text { Harbor seal. Presence/Absence } \\
\text { flag }(0=\text { absent }, 1=\text { present })\end{array}$ \\
\hline & MINKE & 1 & 1 & I & $\begin{array}{l}\text { - Minke whale.Presence/Absence } \\
\text { flag }(0=\text { absent, } 1=\text { present })\end{array}$ \\
\hline & N_SEALION & 1 & 1 & I & $\begin{array}{l}\text { Northern sea lion. } \\
\text { Presence/Absence flag }(0= \\
\text { absent, } 1=\text { present })\end{array}$ \\
\hline & OTTER & 1 & 1 & I & $\begin{array}{l}\text { River otter habitat. } \\
\text { Presence/Absence flag }(0= \\
\text { absent, } 1=\text { present })\end{array}$ \\
\hline
\end{tabular}

INFO NAME DEFINITIONS FOR MAMMAL.AAT FILE:

STANDARD .AAT FILE 
Abstract - The PSEA contains compiled information on the location of marine mammal sightings and haulout sites in the puget sound. The marine mammal data layer in the puget sound GIS is a reproduction of the information presented in the atlas in digital form, with associated database files which store attribute information.

Processing steps- The data layer extraction section in the main text contains the information on processing the sea mammal symbols. Each species data layer from the 12 PSEA regions was composited together with the UNION command. These separate marine mammal data layers were later composited together, also using the UNION command, to form the MAMMAL data layer. Each species was given unique identifiers (the INFO COVERAGE-ID) to aid in creation and attribution of the final composite. These numbers are 1 isted below for the coverage SPECIES.UN-ID, where SPECIES is replaced by the name of the specific mammal, e.g., C_SEALION, (UN= UNIONED).

PSEA Data Unique Feature Identification Numbers:

(From the INFO item SPECIES.UN-ID)

Species ID\# Definition

$\begin{array}{lll}\text { C_SEALION } & 15 & \text { California sea lion } \\ \text { DALL_PORP } & 16 & \text { Dall's porpoise } \\ \text { HARB_PORP } & 17 & \text { Harbor porpoise } \\ \text { HARB_SEAL } & 18 & \text { Harbor seal } \\ \text { MINKE } & 19 & \text { Minke whale } \\ \text { N_SEALION } & 20 & \text { Northern sea lion } \\ \text { OTTER } & 21 & \text { River otter habitat }\end{array}$

A separate data layer was created for each species in the MAMMAL resource-layer. An example INFO Polygon Attribute Table (.PAT) for these specific data layers follows, the item SPECIES is generic for each mammal, e.g., HARB_SEAL:

\section{COLITEM NAMEWDTH OPUT TYP N.DEC DEFINITION}

$\begin{array}{lllllll}1 & \text { AREA } & 4 & 12 & \text { F } & 3 & \begin{array}{l}\text { Area of polygon in square } \\ \text { meters }\end{array} \\ 5 & \text { PERIMETER } & 4 & 12 & \text { F } & 3 & \begin{array}{l}\text { Perimeter of polygon in meters } \\ 9\end{array} \\ \text { SPECIES\# } & 4 & 5 & \text { B } & - & \text { Internal feature number } \\ 13 & \text { SPECIES-ID } & 4 & 5 & \text { B } & - & \text { User-assigned feature number } \\ 17 & \text { SPECIES.UN-ID } 4 & 5 & \text { B } & - & \text { Unique species number }\end{array}$




\section{Marine Fish}

DOCUMENTATION FOR DATA LAYER: Marine Fish, coverage name; (MARINE) SOURCE REFERENCE: Puget Sound Environmental Atlas

MAP PROJECTION: UTM, ZONe 10

PRECISION: Single

TOLERANCES: Fuzzy $=.001$ Dangle $=1.0$

THEME: Puget Sound Marine fish resources

DESCRIPTION: This data layer includes features for a variety of marine fish resources as well as attributes for use type and harvest areas.

CONTACT PERSON/S: Mark Uhrich

CONTACT INSTRUCTIONS: Uhrich 503-251-3292

ORGANIZATION : USGS-WRD

LOCATION DESCRIPTION: Puget Sound Basin

Longitude: $125^{\circ}-120^{\circ}$, Latitude: $46^{\circ} 30-49^{\circ}$

RESOLUTION: $167 \mathrm{ft}(50.9 \mathrm{~m})$

SCALE : $1: 100,000$

ARCHIVE LOCATION: PSWQA; Washington DNR, Division of Aquatic Resources 
COLITEM NAMEWDTH OPUT TYP N.DEC DEFINITION

\begin{tabular}{|c|c|c|c|c|c|c|}
\hline & & & IDA & . PAT & FILE (Polygon) & \\
\hline 17 & SALMON & 1 & 1 & $I$ & $\begin{array}{l}\text { - Presence/Absence flag ( } 1 \\
\text { present, } 0=\text { absent) }\end{array}$ & $=$ \\
\hline 18 & GROUNDFISH & 1 & 1 & $I$ & $\begin{array}{l}\text { Presence/Absence flag ( } 1 \\
\text { present, } 0=\text { absent) }\end{array}$ & $=$ \\
\hline 19 & AREA\# & 3 & 3 & $I$ & $\begin{array}{l}\text { - Groundfish resource and } \\
\text { fishing area number }\end{array}$ & \\
\hline 22 & HERRING_HOLD & 1 & 1 & $I$ & $\begin{array}{l}\text { - Presence/Absence flag (1 } \\
\text { present, } 0=\text { absent) }\end{array}$ & $=$ \\
\hline 23 & HERRING_SPAWN & 1 & 1 & $I$ & $\begin{array}{l}\text { - Presence/Absence flag ( } 1 \\
\text { present, } 0=\text { absent) }\end{array}$ & $=$ \\
\hline 24 & SMELT & 1 & 1 & $I$ & $\begin{array}{l}\text { - Presence/Absence flag (1 } \\
\text { present, } 0=\text { absent) }\end{array}$ & $=$ \\
\hline 25 & COMMERCIAL & 1 & 1 & $I$ & $\begin{array}{l}\text { Presence/Absence flag ( } 1 \\
\text { present, } 0=\text { absent) }\end{array}$ & $=$ \\
\hline 26 & RECREATIONAL & 1 & 1 & $I$ & $\begin{array}{l}\text { Presence/Absence flag ( } 1 \\
\text { present, } 0=\text { absent) }\end{array}$ & $=$ \\
\hline 27 & POTENTIAL_COM & 1 & 1 & $I$ & $\begin{array}{l}\text { - Presence/Absence flag ( } 1 \\
\text { present, } 0=\text { absent) }\end{array}$ & $=$ \\
\hline 28 & AQUACULTURE & 1 & 1 & $I$ & $\begin{array}{l}\text { - Presence/Absence flag ( } 1 \\
\text { present, } 0=\text { absent) }\end{array}$ & $=$ \\
\hline 29 & PEN_CULTURE & 1 & 1 & $I$ & $\begin{array}{l}\text { Presence/Absence flag (1 } \\
\text { present, } 0=\text { absent) }\end{array}$ & $=$ \\
\hline 30 & NONE & 1 & 1 & $I$ & $\begin{array}{l}\text { Polygon has no fish resol } \\
\text { ( } 1=\text { no resource) }\end{array}$ & irce, \\
\hline 31 & UNKNOWN & 1 & 1 & $I$ & $\begin{array}{l}\text { Polygon fish resource un } \\
(1=\text { resource unknown) }\end{array}$ & know \\
\hline
\end{tabular}

Listed below are items from the above. PAT file that are either renamed or added to the marine resource-layer.

COMMERCIAL- Renamed FISH_COM data layer from Salmon Resources. RECREATIONAL - Renamed FISH_SPORT data layer from Salmon Resources. POTENTIAL_COM- Potential Commercial item similar to item in ATLAS Shellfish Resources. Item not populated, added for future updates.

NONE- - Limited or no resource present, item not populated, added for future updates.

UNKNOWN- - Resource unknown, item not populated, added for future updates. 


\section{STANDARD . AAT FILE}

\section{COVERAGE NARRATIVE:}

Abstract - The PSEA contains compiled information on the location of marine fish resources in the Puget Sound. The Marine fish data layer in the Puget Sound GIS is a reproduction of the information presented in the atlas in digital form, with associated database files which store attribute fields.

Processing steps - The Marine fish and Salmon resources are represented in the PSEA as hachure filled polygons or simply as a hachured areal distribution. Reselecting individual resources from the DXF composite coverage was a simple process when a single resource matched a DXF layer. However, when several resources were combined into the same layer the data needed to be separated, either manually or, if possible, automatically, before attribution and final editing.

Marine fish resources were represented cartographically in the PSEA and DXF files three basic ways: (1) Hachured areas with a bounding polygon, (2) Hachured areas without a bounding polygon, and (3) Areas delimited by a broken, or dashed, polygon. See Appendix $E$ for hachure processing steps. The data layer extraction was also conducted using three procedures. The processing of features with a bounding polygon was relatively simple. The delimiting polygon was selected in ARCEDIT and the PUT command was used to place the feature into a new resource data layer for final editing and attribution. Areas represented by hachures without bounding polygons were placed into separate data layers by resource. An AML (linepoly.aml) was used to automatically generate a delimiting polygon in a new coverage. The new coverage was then attributed. Dashed-line polygons required manually connecting the separate line segments to create a closed polygon. In a limited number of polygons, various snapping procedures could be used to automate the connection.

Based on the unique -ID's of the unioned composite, the species/ resource presence/absence flags were populated as were the rest of the final attributes. Each fish species or resource was given a unique identifier (the INFO COVERAGE - ID). The - ID numbers are Iisted below and are for the coverage SPECIES.UN-ID, where SPECIES is replaced by the name of the specific marine fish or resource, e.g., GROUNDFISH, (UN = UNIONED) . 
PSEA Data Unique Feature Identification Numbers:

(From the INFO item SPECIES.UN-ID)

Name ID\# Definition

EX-PEN_CULT 22 Existing pen culture

FISH_COM 23 Salmon resources - Commercial fishing areas

FISH_SPORT 24 Salmon resources - Sport fishing areas

GROUNDFISH 25 Groundfish resource and fishing area

HERR_HOLD 26 Pacific herring holding area

HERR_SPAWN 27 Pacific herring spawning area

SMELT 28 Surf smelt spawning beach

PRO_PEN $\quad 39$ Proposed pen culture

A separate data layer was created for each species or resource in the MARINE resource-layer. An example INFO Polygon Attribute Table (.PAT) for these specific data layers follows, the item SPECIES is generic for a specific fish or resource, e.g., FISH_COM:

COLITEM NAMEWDTH OPUT TYP N.DEC DEFINITION

1 AREA $4 \quad 12$ F 3 Area of polygon in square

5 PERIMETER $\quad 4 \quad 12 \quad$ F 3 Perimeter of polygon in meters

9 SPECIES\# $\quad 4 \quad 5 \quad$ B $\quad$ - Internal feature number

13 SPECIES-ID $4 \quad 5 \quad$ B $\quad$ - User-assigned feature number

17 SPECIES $\quad 2 \quad 2 \quad I \quad$ - Unique species number

19 AREA\# 33 I - Area number for Groundfish

data layer only 


\section{Shellfish}

DOCUMENTATION FOR DATA LAYER: SHELLFISH

SOURCE REFERENCE: Puget Sound Environmental Atlas

MAP PROJECTION: UTM, Zone 10

PRECISION: Single

TOLERANCES: Fuzzy $=.001$ Dangle $=1.0$

THEME: Puget Sound Shellfish resources

DESCRIPTION: This data layer includes features for a variety of shellfish resources, as well as attributes for use type and aquaculture harvest areas.

CONTACT PERSON/S: Mark Uhrich

CONTACT INSTRUCTIONS: Uhrich 503-251-3292

ORGANIZATION: USGS-WRD

LOCATION DESCRIPTION: Puget Sound Basin

Longitude: $125^{\circ}-120^{\circ}$, Latitude: $46^{\circ} 30-49^{\circ}$

RESOLUTION : $167 \mathrm{ft}(50.9 \mathrm{~m})$

SCALE: $1: 100,000$

ARCHIVE LOCATION: PSWQA; Washington DNR, Division of Aquatic Resources 
INFO ITEM DEFINITIONS FOR SHELLFISH.PAT FILE:

COLITEM NAMEWDTH OPUT TYP N.DEC DEFINITION

17 CLAMS

18 GEODUCKS

19 CRAB

20 SHRIMP

21 OYSTERS

22 MUSSELS

23 COMMERCIAL

24 RECREATIONAL

25 POTENTIAL_COM 11

26 AQUACULTURE 111 I

27 BOTTOM_CULT 111 I

28 SUSPENDED_CULT1 1 I

29 NONE

$111 \quad I$

30 UNKNOWN

\section{STANDARD .PAT FILE (POIygOn)}

11 I - Presence/Absence flag ( 1 = present, $0=a b s e n t$ )

Presence/Absence flag $(1=$ present, $0=$ absent)

Presence/Absence flag $(1=$ present, $0=$ absent)

Presence/Absence flag $(1=$ present, $0=$ absent)

Presence/Absence flag ( $1=$ present, $0=$ absent)

Presence/Absence flag $(1=$ present, $0=$ absent)

Presence/Absence flag $(1=$ present, $0=$ absent)

Presence/Absence flag $(1=$ present, $0=$ absent

Presence/Absence flag $(1=$ present, $0=$ absent)

Presence/Absence flag $(1=$ present, $0=$ absent)

Presence/Absence flag $(1=$ present, $0=$ absent)

Presence/Absence flag ( 1 = present, $0=$ absent)

Polygon has no shellfish resource, ( 1 = no resource) Polygon shellfish resource unknown, ( 1 = resource unknown) 
Listed below are items from the above. PAT file that are either renamed or added to the shellfish resource-layer.

COMMERCIAL- Commercial clam, oyster and geoduck beds. Composite of CLAM_OY and GEO_COM.

RECREATIONAL - Item similar to Sport Fishing Areas from ATLAS Salmon Resources. Item not populated, added for future updates.

POTENTIAL_COM- Potential Commercial beds not currently utilized. Composite of CLAM_MAJ and GEO_MAJ.

NONE- - Limited or no shellfish resource present, item not populated, added for future updates.

UNKNOWN-- Shellfish resource unknown, item not populated, added for future updates.

INFO NAME DEFINITIONS FOR SHELLFISH.AAT FILE:

$$
\text { STANDARD . AAT FILE }
$$

COVERAGE NARRATIVE:

Abstract - The PSEA contains compiled information on the location of shellfish resources in the Puget sound. The Shellfish data layer in the Puget sound GIS is a reproduction of the information presented in the atlas in digital form, with associated database files which store attribute fields.

Processing steps - The Shellfish resources are represented in the PSEA as hachure filled polygons or simply a hachured areal distribution. Reselecting individual resources from the DXF composite coverage was a simple process when a single resource matched a DXF layer. However, when several resources were combined into the same layer the data needed to be separated, either manually or in some cases automatically, before attribution and final editing.

Shellfish resources were represented cartographically in the PSEA and DXF files as hachured areas, both bounded and unbounded polygons, and as dash-lined polygons without hachures. The processing methods were identical to the MARINE resource-layer. Each shellfish species or resource was given a unique identifier (the INFO COVERAGE-ID). The - ID numbers are listed below and are for the coverage SPECIES.UN-ID, where SPECIES is replaced by the name of the specific shellfish species or resource, for example, GEO_COM, (UN= UNIONED). 
PSEA Data Unique Feature Identification Numbers:

(From the INFO item SPECIES.UN-ID)

Name ID\# Definition

B_CULT 29 Bottom culture

CLAM_MAJ 30 Subtidal clams-major, potential commercial beds

CLAM_OY 31 Clams and oysters-commercial

CRAB - 32 Dungeness crab

GEO_COM 33 Geoducks commercial

GEO_MAJ 34 Geoducks-major, potential commercial beds

OYSTERS $\quad 35$ Oysters commercial

SHRIMP $\quad 36 \quad$ Shrimp

SUSP_CULT 37 Suspended culture

A separate data layer was created for each species or resource in the SHELLFISH resource-layer. An example INFO Polygon Attribute Table (.PAT) for these specific data layers follows, the term SPECIES would be replaced by the specific shellfish or resource, e.g., CRAB:

COLITEM NAMEWDTH OPUT TYP N.DEC DEFINITION

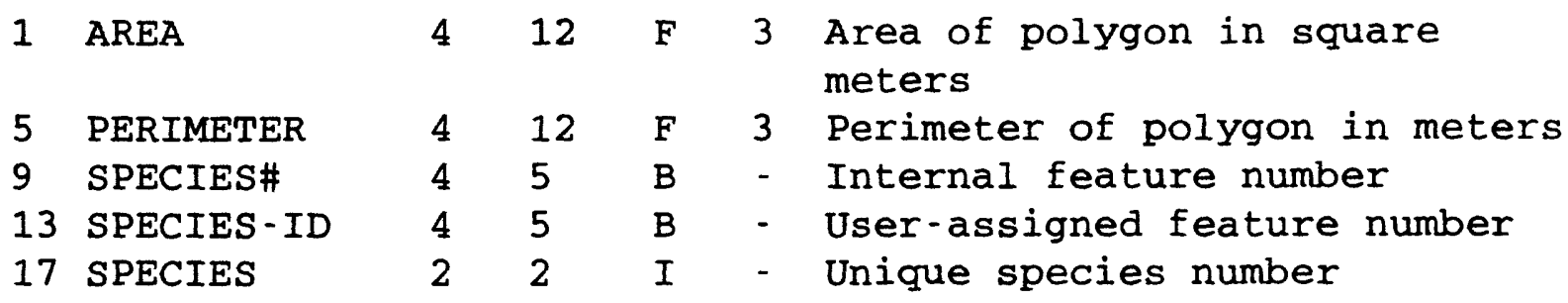




\section{APPENDIX C}

\section{Tic-Identification Numbers and Coordinates}

(All tics are numbered starting from the upper right corner and moving to the left, except for Region 3, which starts from the upper left corner and moves to the right. Tic-ID, Tic-identificaton number)

\begin{tabular}{|c|c|c|c|c|c|}
\hline Tic-ID & Longitude & Latitude & Tic-1D & Longitude & Latitude \\
\hline \multicolumn{6}{|c|}{ Region 1: Tics 1-24 } \\
\hline 101 & $-122^{\circ} 40^{\prime} 00^{\prime \prime}$ & $48^{\circ} 55^{\prime} 00^{\prime \prime}$ & 102 & $-122^{\circ} 45^{\prime} 00^{\prime \prime}$ & $48^{\circ} 55^{\prime} 00^{\prime \prime}$ \\
\hline 103 & $-122^{\circ} 50^{\prime} 00^{\prime \prime}$ & $48^{\circ} 55^{\prime} 00^{\prime \prime}$ & 104 & $-122^{\circ} 55^{\prime} 00^{\prime \prime}$ & $48^{\circ} 55^{\prime} 00^{\prime \prime}$ \\
\hline 105 & $-123^{\circ} 00^{\prime} 00^{\prime \prime}$ & $48^{\circ} 55^{\prime} 00^{\prime \prime}$ & 106 & $-123^{\circ} 05^{\prime} 00^{\prime \prime}$ & $48^{\circ} 55^{\prime} 00^{\prime \prime}$ \\
\hline 107 & $-123^{\circ} 10^{\prime} 00^{\prime \prime}$ & $48^{\circ} 55^{\prime} 00^{\prime \prime}$ & 108 & $-123^{\circ} 15^{\prime} 00^{\prime \prime}$ & $48^{\circ} 55^{\prime} 00^{\prime \prime}$ \\
\hline 109 & $-122^{\circ} 40^{\prime} 00^{\prime \prime}$ & $48^{\circ} 50^{\prime} 00^{\prime \prime}$ & 110 & $-122^{\circ} 45^{\prime} 00^{\prime \prime}$ & $48^{\circ} 50^{\prime} 00^{\prime \prime}$ \\
\hline 111 & $-122^{\circ} 50^{\prime} 00^{\prime \prime}$ & $48^{\circ} 50^{\prime} 00^{\prime \prime}$ & 112 & $-122^{\circ} 55^{\prime} 00^{\prime \prime}$ & $48^{\circ} 50^{\prime} 00^{\prime \prime}$ \\
\hline 113 & $-123^{\circ} 00^{\prime} 00^{\prime \prime}$ & $48^{\circ} 50^{\prime} 00^{\prime \prime}$ & 114 & $-123^{\circ} 05^{\prime} 00^{\prime \prime}$ & $48^{\circ} 50^{\circ} 00^{\prime \prime}$ \\
\hline 115 & $-123^{\circ} 10^{\prime} 00^{\prime \prime}$ & $48^{\circ} 50^{\prime} 00^{\prime \prime}$ & 116 & $-123^{\circ} 15^{\prime} 00^{\prime \prime}$ & $48^{\circ} 50^{\prime} 00^{\prime \prime}$ \\
\hline 117 & $-122^{\circ} 40^{\prime} 00^{\prime \prime}$ & $48^{\circ} 45^{\prime} 00^{\prime \prime}$ & 118 & $-122^{\circ} 45^{\prime} 00^{\prime \prime}$ & $48^{\circ} 45^{\prime} 00^{\prime \prime}$ \\
\hline 119 & $-122^{\circ} 50^{\prime} 00^{\prime \prime}$ & $48^{\circ} 45^{\prime} 00^{\prime \prime}$ & 120 & $-122^{\circ} 55^{\prime} 00^{\prime \prime}$ & $48^{\circ} 45^{\circ} 00^{\prime \prime}$ \\
\hline 121 & $-123^{\circ} 00^{\prime} 00^{\prime \prime}$ & $48^{\circ} 45^{\prime} 00^{\prime \prime}$ & 122 & $-123^{\circ} 05^{\prime} 00^{\prime \prime}$ & $48^{\circ} 45^{\prime} 00^{\prime \prime}$ \\
\hline 123 & $-123^{\circ} 10^{\prime} 00^{\prime \prime}$ & $48^{\circ} 45^{\prime} 00^{\prime \prime}$ & 124 & $-123^{\circ} 15^{\prime} 00^{\prime \prime}$ & $48^{\circ} 45^{\circ} 00^{\prime \prime}$ \\
\hline
\end{tabular}




\begin{tabular}{|c|c|c|c|c|c|}
\hline TIC-ID & Longitude & Latitude & Tic-ID & Longitude & Latitude \\
\hline \multicolumn{6}{|c|}{ Region 2: Tics 1-55 } \\
\hline 201 & $-122^{\circ} 25^{\prime} 00^{\prime \prime}$ & $48^{\circ} 45^{\prime} 00^{\prime \prime}$ & 202 & $-122^{\circ} 30^{\prime} 00^{\prime \prime}$ & $48^{\circ} 45^{\prime} 00^{\prime \prime}$ \\
\hline 203 & $-122^{\circ} 35^{\prime} 00^{\prime \prime}$ & $48^{\circ} 45^{\prime} 00^{\prime \prime}$ & 204 & $-122^{\circ} 40^{\prime} 00^{\prime \prime}$ & $48^{\circ} 45^{\prime} 00^{\prime \prime}$ \\
\hline 205 & $-122^{\circ} 45^{\prime} 00^{\prime \prime}$ & $48^{\circ} 45^{\prime} 00^{\prime \prime}$ & 206 & $-122^{\circ} 50^{\prime} 00^{\prime \prime}$ & $48^{\circ} 45^{\prime} 00^{\prime \prime}$ \\
\hline 207 & $-122^{\circ} 55^{\prime} 00^{\prime \prime}$ & $48^{\circ} 45^{\prime} 00^{\prime \prime}$ & 208 & $-123^{\circ} 00^{\prime} 00^{\prime \prime}$ & $48^{\circ} 45^{\prime} 00^{\prime \prime}$ \\
\hline 209 & $-123^{\circ} 05^{\prime} 00^{\prime \prime}$ & $48^{\circ} 45^{\prime} 00^{\prime \prime}$ & 210 & $-123^{\circ} 10^{\prime} 00^{\prime \prime}$ & $48^{\circ} 45^{\prime} 00^{\prime \prime}$ \\
\hline 211 & $-123^{\circ} 15^{\prime} 00^{\prime \prime}$ & $48^{\circ} 45^{\prime} 00^{\prime \prime}$ & 212 & $-122^{\circ} 25^{\prime} 00^{\prime \prime}$ & $48^{\circ} 40^{\prime} 00^{\prime \prime}$ \\
\hline 213 & $-122^{\circ} 30^{\prime} 00^{\prime \prime}$ & $48^{\circ} 40^{\prime} 00^{\prime \prime}$ & 214 & $-122^{\circ} 35^{\prime} 00^{\prime \prime}$ & $48^{\circ} 40^{\prime} 00^{\prime \prime}$ \\
\hline 215 & $-122^{\circ} 40^{\prime} 00^{\prime \prime}$ & $48^{\circ} 40^{\prime} 00^{\prime \prime}$ & 216 & $-122^{\circ} 45^{\prime} 00^{\prime \prime}$ & $48^{\circ} 40^{\prime} 00^{\prime \prime}$ \\
\hline 217 & $-122^{\circ} 50^{\prime} 00^{\prime \prime}$ & $48^{\circ} 40^{\prime} 00^{\prime \prime}$ & 218 & $-122^{\circ} 55^{\prime} 00^{\prime \prime}$ & $48^{\circ} 40^{\prime} 00^{\prime \prime}$ \\
\hline 219 & $-123^{\circ} 00^{\prime} 00^{\prime \prime}$ & $48^{\circ} 40^{\prime} 00^{\prime \prime}$ & 220 & $-123^{\circ} 05^{\prime} 00^{\prime \prime}$ & $48^{\circ} 40^{\prime} 00^{\prime \prime}$ \\
\hline 221 & $-123^{\circ} 10^{\prime} 00^{\prime \prime}$ & $48^{\circ} 40^{\prime} 00^{\prime \prime}$ & 222 & $-123^{\circ} 15^{\prime} 00^{\prime \prime}$ & $48^{\circ} 40^{\prime} 00^{\prime \prime}$ \\
\hline 223 & $-122^{\circ} 25^{\prime} 00^{\prime \prime}$ & $48^{\circ} 35^{\prime} 00^{\prime \prime}$ & 224 & $-122^{\circ} 30^{\prime} 00^{\prime \prime}$ & $48^{\circ} 35^{\prime} 00^{\prime \prime}$ \\
\hline 225 & $-122^{\circ} 35^{\prime} 00^{\prime \prime}$ & $48^{\circ} 35^{\prime} 00^{\prime \prime}$ & 226 & $-122^{\circ} 40^{\prime} 00^{\prime \prime}$ & $48^{\circ} 35^{\prime} 00^{\prime \prime}$ \\
\hline 227 & $-122^{\circ} 45^{\prime} 00^{\prime \prime}$ & $48^{\circ} 35^{\prime} 00^{\prime \prime}$ & 228 & $-122^{\circ} 50^{\prime} 00^{\prime \prime}$ & $48^{\circ} 35^{\prime} 00^{\prime \prime}$ \\
\hline 229 & $-122^{\circ} 55^{\prime} 00^{\prime \prime}$ & $48^{\circ} 35^{\prime} 00^{\prime \prime}$ & 230 & $-123^{\circ} 00^{\prime} 00^{\prime \prime}$ & $48^{\circ} 35^{\prime} 00^{\prime \prime}$ \\
\hline 231 & $-123^{\circ} 05^{\prime} 00^{\prime \prime}$ & $48^{\circ} 35^{\prime} 00^{\prime \prime}$ & 232 & $-123^{\circ} 10^{\prime} 00^{\prime \prime}$ & $48^{\circ} 35^{\prime} 00^{\prime \prime}$ \\
\hline 233 & $-123^{\circ} 15^{\prime} 00^{\prime \prime}$ & $48^{\circ} 35^{\prime} 00^{\prime \prime}$ & 234 & $-122^{\circ} 25^{\prime} 00^{\prime \prime}$ & $48^{\circ} 30^{\prime} 00^{\prime \prime}$ \\
\hline 235 & $-122^{\circ} 30^{\prime} 00^{\prime \prime}$ & $48^{\circ} 30^{\prime} 00^{\prime \prime}$ & 236 & $-122^{\circ} 35^{\prime} 00^{\prime \prime}$ & $48^{\circ} 30^{\prime} 00^{\prime \prime}$ \\
\hline 237 & $-122^{\circ} 40^{\prime} 00^{\prime \prime}$ & $48^{\circ} 30^{\circ} 00^{\prime \prime}$ & 238 & $-122^{\circ} 45^{\prime} 00^{\prime \prime}$ & $48^{\circ} 30^{\prime} 00^{\prime \prime}$ \\
\hline 239 & $-122^{\circ} 50^{\prime} 00^{\prime \prime}$ & $48^{\circ} 30^{\prime} 00^{\prime \prime}$ & 240 & $-122^{\circ} 55^{\prime} 00^{\prime \prime}$ & $48^{\circ} 30^{\prime} 00^{\prime \prime}$ \\
\hline 241 & $-123^{\circ} 00^{\prime} 00^{\prime \prime}$ & $48^{\circ} 30^{\prime} 00^{\prime \prime}$ & 242 & $-123^{\circ} 05^{\prime} 00^{\prime \prime}$ & $48^{\circ} 30^{\prime} 00^{\prime \prime}$ \\
\hline 243 & $-123^{\circ} 10^{\prime} 00^{\prime \prime}$ & $48^{\circ} 30^{\circ} 00^{\prime \prime}$ & 244 & $-123^{\circ} 15^{\prime} 00^{\prime \prime}$ & $48^{\circ} 30^{\prime} 00^{\prime \prime}$ \\
\hline 245 & $-122^{\circ} 25^{\prime} 00^{\prime \prime}$ & $48^{\circ} 25^{\prime} 00^{\prime \prime}$ & 246 & $-122^{\circ} 30^{\prime} 00^{\prime \prime}$ & $48^{\circ} 25^{\prime} 00^{\prime \prime}$ \\
\hline 247 & $-122^{\circ} 35^{\prime} 00^{\prime \prime}$ & $48^{\circ} 25^{\prime} 00^{\prime \prime}$ & 248 & $-122^{\circ} 40^{\prime} 00^{\prime \prime}$ & $48^{\circ} 25^{\prime} 00^{\prime \prime}$ \\
\hline 249 & $-122^{\circ} 45^{\prime} 00^{\prime \prime}$ & $48^{\circ} 25^{\prime} 00^{\prime \prime}$ & 250 & $-122^{\circ} 50^{\prime} 00^{\prime \prime}$ & $48^{\circ} 25^{\prime} 00^{\prime \prime}$ \\
\hline 251 & $-122^{\circ} 55^{\prime} 00^{\prime \prime}$ & $48^{\circ} 25^{\prime} 00^{\prime \prime}$ & 252 & $-123^{\circ} 00^{\prime} 00^{\prime \prime}$ & $48^{\circ} 25^{\prime} 00^{\prime \prime}$ \\
\hline 253 & $-123^{\circ} 05^{\prime} 00^{\prime \prime}$ & $48^{\circ} 25^{\prime} 00^{\prime \prime}$ & 254 & $-123^{\circ} 10^{\prime} 00^{\prime \prime}$ & $48^{\circ} 25^{\prime} 00^{\prime \prime}$ \\
\hline 255 & $-123^{\circ} 15^{\prime} 00^{\prime \prime}$ & $48^{\circ} 25^{\prime} 00^{\prime \prime}$ & & & \\
\hline
\end{tabular}




\begin{tabular}{|c|c|c|c|c|c|}
\hline Tic-ID & Longitude & Latitude & TIC-1D & Longitude & Latitude \\
\hline \multicolumn{6}{|c|}{ Region 3: Tics 1-32 } \\
\hline 301 & $-123^{\circ} 27^{\prime} 30^{\prime \prime}$ & $48^{\circ} 22^{\prime} 30^{\prime \prime}$ & 302 & $-123^{\circ} 22^{\prime} 30^{\prime \prime}$ & $48^{\circ} 22^{\prime} 30^{\prime \prime}$ \\
\hline 303 & $-123^{\circ} 17^{\prime} 30^{\prime \prime}$ & $48^{\circ} 22^{\prime} 30^{\prime \prime}$ & 304 & $-123^{\circ} 12^{\prime} 30^{\prime \prime}$ & $48^{\circ} 22^{\prime} 30^{\prime \prime}$ \\
\hline 305 & $-123^{\circ} 07^{\prime} 30^{\prime \prime}$ & $48^{\circ} 22^{\prime} 30^{\prime \prime}$ & 306 & $-123^{\circ} 02^{\prime} 30^{\prime \prime}$ & $48^{\circ} 22^{\prime} 30^{\prime \prime}$ \\
\hline 307 & $-122^{\circ} 57^{\prime} 30^{\prime \prime}$ & $48^{\circ} 22^{\prime} 30^{\prime \prime}$ & 308 & $-122^{\circ} 52^{\prime} 30^{\prime \prime}$ & $48^{\circ} 22^{\prime} 30^{\prime \prime}$ \\
\hline 309 & $-123^{\circ} 27^{\prime} 30^{\prime \prime}$ & $48^{\circ} 17^{\prime} 30^{\prime \prime}$ & 310 & $-123^{\circ} 22^{\prime} 30^{\prime \prime}$ & $48^{\circ} 17^{\prime} 30^{\prime \prime}$ \\
\hline 311 & $-123^{\circ} 17^{\prime} 30^{\prime \prime}$ & $48^{\circ} 17^{\prime} 30^{\prime \prime}$ & 312 & $-123^{\circ} 12^{\prime} 30^{\prime \prime}$ & $48^{\circ} 17^{\prime} 30^{\prime \prime}$ \\
\hline 313 & $-123^{\circ} 07^{\prime} 30^{\prime \prime}$ & $48^{\circ} 17^{\prime} 30^{\prime \prime}$ & 314 & $-123^{\circ} 02^{\prime} 30^{\prime \prime}$ & $48^{\circ} 17^{\prime} 30^{\prime \prime}$ \\
\hline 315 & $-122^{\circ} 57^{\prime} 30^{\prime \prime}$ & $48^{\circ} 17^{\prime} 30^{\prime \prime}$ & 316 & $-122^{\circ} 52^{\prime} 30^{\prime \prime}$ & $48^{\circ} 17^{\prime} 30^{\prime \prime}$ \\
\hline 317 & $-123^{\circ} 27^{\prime} 30^{\prime \prime}$ & $48^{\circ} 12^{\prime} 30^{\prime \prime}$ & 318 & $-123^{\circ} 22^{\prime} 30^{\prime \prime}$ & $48^{\circ} 12^{\prime} 30^{\prime \prime}$ \\
\hline 319 & $-123^{\circ} 17^{\prime} 30^{\prime \prime}$ & $48^{\circ} 12^{\prime} 30^{\prime \prime}$ & 320 & $-123^{\circ} 12^{\prime} 30^{\prime \prime}$ & $48^{\circ} 12^{\prime} 30^{\prime \prime}$ \\
\hline 321 & $-123^{\circ} 07^{\prime} 30^{\prime \prime}$ & $48^{\circ} 12^{\prime} 30^{\prime \prime}$ & 322 & $-123^{\circ} 02^{\prime} 30^{\prime \prime}$ & $48^{\circ} 12^{\prime} 30^{\prime \prime}$ \\
\hline 323 & $-122^{\circ} 57^{\prime} 30^{\prime \prime}$ & $48^{\circ} 12^{\prime} 30^{\prime \prime}$ & 324 & $-122^{\circ} 52^{\prime} 30^{\prime \prime}$ & $48^{\circ} 12^{\prime} 30^{\prime \prime}$ \\
\hline 325 & $-123^{\circ} 27^{\prime} 30^{\prime \prime}$ & $48^{\circ} 07^{\prime} 30^{\prime \prime}$ & 326 & $-123^{\circ} 22^{\prime} 30^{\prime \prime}$ & $48^{\circ} 07^{\prime} 30^{\prime \prime}$ \\
\hline 327 & $-123^{\circ} 17 \cdot 30^{\prime \prime}$ & $48^{\circ} 07^{\prime} 30^{\prime \prime}$ & 328 & $-123^{\circ} 12^{\prime} 30^{\prime \prime}$ & $48^{\circ} 07^{\prime} 30^{\prime \prime}$ \\
\hline 329 & $-123^{\circ} 07^{\prime} 30^{\prime \prime}$ & $48^{\circ} 07^{\prime} 30^{\prime \prime}$ & 330 & $-123^{\circ} 02^{\prime} 30^{\prime \prime}$ & $48^{\circ} 07^{\prime} 30^{\prime \prime}$ \\
\hline 331 & $-122^{\circ} 57^{\prime} 30^{\prime \prime}$ & $48^{\circ} 07^{\prime} 30^{\prime \prime}$ & 332 & $-122^{\circ} 52^{\prime} 30^{\prime \prime}$ & $48^{\circ} 07^{\prime} 30^{\prime \prime}$ \\
\hline \multicolumn{6}{|c|}{ Reqion 4: Tics 1-21 } \\
\hline 401 & $-122^{\circ} 22^{\prime} 30^{\prime \prime}$ & $48^{\circ} 22^{\prime} 30^{\prime \prime}$ & 402 & $-122^{\circ} 27^{\prime} 30^{\prime \prime}$ & $48^{\circ} 22^{\prime} 30^{\prime \prime}$ \\
\hline 403 & $-122^{\circ} 32^{\prime} 30^{\prime \prime}$ & $48^{\circ} 22^{\prime} 30^{\prime \prime}$ & 404 & $-122^{\circ} 37^{\prime} 30^{\prime \prime}$ & $48^{\circ} 22^{\prime} 30^{\prime \prime}$ \\
\hline 405 & $-122^{\circ} 42^{\prime} 30^{\prime \prime}$ & $48^{\circ} 22^{\prime} 30^{\prime \prime}$ & 406 & $-122^{\circ} 47^{\prime} 30^{\prime \prime}$ & $48^{\circ} 22^{\prime} 30^{\prime \prime}$ \\
\hline 407 & $-122^{\circ} 52^{\prime} 30^{\prime \prime}$ & $48^{\circ} 22^{\prime} 30^{\prime \prime}$ & 408 & $-122^{\circ} 22^{\prime} 30^{\prime \prime}$ & $48^{\circ} 17^{\prime} 30^{\prime \prime}$ \\
\hline 409 & $-122^{\circ} 27^{\prime} 30^{\prime \prime}$ & $48^{\circ} 17^{\prime} 30^{\prime \prime}$ & 410 & $-122^{\circ} 32^{\prime} 30^{\prime \prime}$ & $48^{\circ} 17^{\prime} 30^{\prime \prime}$ \\
\hline 411 & $-122^{\circ} 37^{\prime} 30^{\prime \prime}$ & $48^{\circ} 17^{\prime} 30^{\prime \prime}$ & 412 & $-122^{\circ} 42^{\prime} 30^{\prime \prime}$ & $48^{\circ} 17^{\prime} 30^{\prime \prime}$ \\
\hline 413 & $-122^{\circ} 47^{\prime} 30^{\prime \prime}$ & $48^{\circ} 17^{\prime} 30^{\prime \prime}$ & 414 & $-122^{\circ} 52^{\prime} 30^{\prime \prime}$ & $48^{\circ} 17^{\prime} 30^{\prime \prime}$ \\
\hline 415 & $-122^{\circ} 22^{\prime} 30^{\prime \prime}$ & $48^{\circ} 12^{\prime} 30^{\prime \prime}$ & 416 & $-122^{\circ} 27^{\prime} 30^{\prime \prime}$ & $48^{\circ} 12^{\prime} 30^{\prime \prime}$ \\
\hline 417 & $-122^{\circ} 32^{\prime} 30^{\prime \prime}$ & $48^{\circ} 12^{\prime} 30^{\prime \prime}$ & 418 & $-122^{\circ} 37^{\prime} 30^{\prime \prime}$ & $48^{\circ} 12^{\prime} 30^{\prime \prime}$ \\
\hline 419 & $-122^{\circ} 42^{\prime} 30^{\prime \prime}$ & $48^{\circ} 12^{\prime} 30^{\prime \prime}$ & 420 & $-122^{\circ} 47^{\prime} 30^{\prime \prime}$ & $48^{\circ} 12^{\prime} 30^{\prime \prime}$ \\
\hline 421 & $-122^{\circ} 52^{\prime} 30^{\prime \prime}$ & $48^{\circ} 12^{\prime} 30^{\prime \prime}$ & & & \\
\hline
\end{tabular}




\begin{tabular}{llllll}
\hline Tic-ID & Longitude & Latitude & Tic-ID & Longitude & Latitude \\
\hline
\end{tabular}

Region 5: Tics 1-21

\begin{tabular}{|c|c|c|c|c|c|}
\hline 501 & $-122^{\circ} 32^{\prime} 30^{\prime \prime}$ & $48^{\circ} 10^{\prime} 00^{\prime \prime}$ & 502 & $-122^{\circ} 37^{\prime} 30^{\prime \prime}$ & $48^{\circ} 10^{\prime} 00^{\prime \prime}$ \\
\hline 503 & $-122^{\circ} 42^{\prime} 30^{\prime \prime}$ & $48^{\circ} 10^{\prime} 00^{\prime \prime}$ & 504 & $-122^{\circ} 47^{\prime} 30^{\prime \prime}$ & $48^{\circ} 10^{\prime} 00^{\prime \prime}$ \\
\hline 505 & $-122^{\circ} 52^{\prime} 30^{\prime \prime}$ & $48^{\circ} 10^{\prime} 00^{\prime \prime}$ & 506 & $-122^{\circ} 57^{\prime} 30^{\prime \prime}$ & $48^{\circ} 10^{\prime} 00^{\prime \prime}$ \\
\hline 507 & $-123^{\circ} 02^{\prime} 30^{\prime \prime}$ & $48^{\circ} 10^{\prime} 00^{\prime \prime}$ & 508 & $-122^{\circ} 32^{\prime} 30^{\prime \prime}$ & $48^{\circ} 05^{\prime} 00^{\prime \prime}$ \\
\hline 509 & $-122^{\circ} 37^{\prime} 30^{\prime \prime}$ & $48^{\circ} 05^{\prime} 00^{\prime \prime}$ & 510 & $-122^{\circ} 42^{\prime} 30^{\prime \prime}$ & $48^{\circ} 05^{\prime} 00^{\prime \prime}$ \\
\hline 511 & $-122^{\circ} 47^{\prime} 30^{\prime \prime}$ & $48^{\circ} 05^{\prime} 00^{\prime \prime}$ & 512 & $-122^{\circ} 52^{\prime} 30^{\prime \prime}$ & $48^{\circ} 05^{\prime} 00^{\prime \prime}$ \\
\hline 513 & $-122^{\circ} 57^{\prime} 30^{\prime \prime}$ & $48^{\circ} 05^{\prime} 00^{\prime \prime}$ & 514 & $-123^{\circ} 02^{\prime} 30^{\prime \prime}$ & $48^{\circ} 05^{\prime} 00^{\prime \prime}$ \\
\hline 515 & $-122^{\circ} 32^{\prime} 30^{\prime \prime}$ & $48^{\circ} 00^{\prime} 00^{\prime \prime}$ & 516 & $-122^{\circ} 37^{\prime} 30^{\prime \prime}$ & $48^{\circ} 00^{\prime} 00^{\prime \prime}$ \\
\hline 517 & $-122^{\circ} 42^{\prime} 30^{\prime \prime}$ & $48^{\circ} 00^{\prime} 00^{\prime \prime}$ & 518 & $-122^{\circ} 47^{\prime} 30^{\prime \prime}$ & $48^{\circ} 00^{\prime} 00$ \\
\hline 519 & $-122^{\circ} 52^{\prime} 30^{\prime \prime}$ & $48^{\circ} 00^{\prime} 00^{\prime \prime}$ & 520 & $-122^{\circ} 57^{\prime} 30^{\prime \prime}$ & $48^{\circ} 00^{\prime} 00$ \\
\hline 521 & $-123^{\circ} 02^{\prime} 30^{\prime \prime}$ & $48^{\circ} 00^{\prime} 00^{\prime \prime}$ & & & \\
\hline
\end{tabular}

Region 6: Tics 1-25

$\begin{array}{llllll}601 & -122^{\circ} 10^{\prime} 00^{\prime \prime} & 48^{\circ} 15^{\prime} 00^{\prime \prime} & 602 & -122^{\circ} 15^{\prime} 00^{\prime \prime} & 48^{\circ} 15^{\prime} 00^{\prime \prime} \\ 603 & -122^{\circ} 20^{\prime} 00^{\prime \prime} & 48^{\circ} 15^{\prime} 00^{\prime \prime} & 604 & -122^{\circ} 25^{\prime} 00^{\prime \prime} & 48^{\circ} 15^{\prime} 00^{\prime \prime} \\ 605 & -122^{\circ} 30^{\prime} 00^{\prime \prime} & 48^{\circ} 15^{\prime} 00^{\prime \prime} & 606 & -122^{\circ} 10^{\prime} 00^{\prime \prime} & 48^{\circ} 10^{\prime} 00^{\prime \prime} \\ 607 & -122^{\circ} 15^{\prime} 00^{\prime \prime} & 48^{\circ} 10^{\prime} 00^{\prime \prime} & 608 & -122^{\circ} 20^{\prime} 00^{\prime \prime} & 48^{\circ} 10^{\prime} 00^{\prime \prime} \\ 609 & -122^{\circ} 25^{\prime} 00^{\prime \prime} & 48^{\circ} 10^{\prime} 00^{\prime \prime} & 610 & -122^{\circ} 30^{\prime} 00^{\prime \prime} & 48^{\circ} 10^{\prime} 00^{\prime \prime} \\ 611 & -122^{\circ} 10^{\prime} 00^{\prime \prime} & 48^{\circ} 05^{\prime} 00^{\prime \prime} & 612 & -122^{\circ} 15^{\prime} 00^{\prime \prime} & 48^{\circ} 05^{\prime} 00^{\prime \prime} \\ 613 & -122^{\circ} 20^{\prime} 00^{\prime \prime} & 48^{\circ} 05^{\prime} 00^{\prime \prime} & 614 & -122^{\circ} 25^{\prime} 00^{\prime \prime} & 48^{\circ} 05^{\prime} 00^{\prime \prime} \\ 615 & -122^{\circ} 30^{\prime} 00^{\prime \prime} & 48^{\circ} 05^{\prime} 00^{\prime \prime} & 616 & -122^{\circ} 10^{\prime} 00^{\prime \prime} & 48^{\circ} 00^{\prime} 00^{\prime \prime} \\ 617 & -122^{\circ} 15^{\prime} 00^{\prime \prime} & 48^{\circ} 00^{\prime} 00^{\prime \prime} & 618 & -122^{\circ} 20^{\prime} 00^{\prime \prime} & 48^{\circ} 00^{\prime} 00^{\prime \prime} \\ 619 & -122^{\circ} 25^{\prime} 00^{\prime \prime} & 48^{\circ} 00^{\prime} 00^{\prime \prime} & 620 & -122^{\circ} 30^{\prime} 00^{\prime \prime} & 48^{\circ} 00^{\prime} 00^{\prime \prime} \\ 621 & -122^{\circ} 10^{\prime} 00^{\prime \prime} & 47^{\circ} 55^{\prime} 00^{\prime \prime} & 622 & -122^{\circ} 15^{\prime} 00^{\prime \prime} & 47^{\circ} 55^{\prime} 00^{\prime \prime} \\ 623 & -122^{\circ} 20^{\prime} 00^{\prime \prime} & 47^{\circ} 55^{\prime} 00^{\prime \prime} & 624 & -122^{\circ} 25^{\prime} 00^{\prime \prime} & 47^{\circ} 55^{\prime} 00^{\prime \prime} \\ 625 & -122^{\circ} 30^{\prime} 00^{\prime \prime} & 47^{\circ} 55^{\prime} 00^{\prime \prime} & & & \end{array}$

\section{Region 7: Tics 1-25}

$\begin{array}{ll}701 & -122^{\circ} 45^{\prime} 00^{\prime \prime} \\ 703 & -122^{\circ} 55^{\prime} 00^{\prime \prime} \\ 705 & -123^{\circ} 05^{\prime} 00^{\prime \prime} \\ 707 & -122^{\circ} 50^{\prime} 00^{\prime \prime} \\ 709 & -122^{\circ} 60^{\prime} 00^{\prime \prime} \\ 711 & -122^{\circ} 45^{\prime} 00^{\prime \prime} \\ 713 & -122^{\circ} 55^{\prime} 00^{\prime \prime} \\ 715 & -123^{\circ} 05^{\prime} 00^{\prime \prime} \\ 717 & -122^{\circ} 50^{\prime} 00^{\prime \prime} \\ 719 & -122^{\circ} 60^{\prime} 00^{\prime \prime} \\ 721 & -122^{\circ} 45^{\prime} 00^{\prime \prime} \\ 723 & -122^{\circ} 55^{\prime} 00^{\prime \prime} \\ 725 & -123^{\circ} 05^{\circ} 00^{\prime \prime}\end{array}$

$\begin{array}{lll}47^{\circ} 52^{\prime} 30^{\prime \prime} & 702 & -122^{\circ} 50^{\prime} 00^{\prime \prime} \\ 47^{\circ} 52^{\prime} 30^{\prime \prime} & 704 & -122^{\circ} 60^{\prime} 00^{\prime \prime} \\ 47^{\circ} 52^{\prime} 30^{\prime \prime} & 706 & -122^{\circ} 45^{\prime} 00^{\prime \prime} \\ 47^{\circ} 47^{\prime} 30^{\prime \prime} & 708 & -122^{\circ} 55^{\prime} 00^{\prime \prime} \\ 47^{\circ} 47^{\prime} 30^{\prime \prime} & 710 & -123^{\circ} 05^{\prime} 00^{\prime \prime} \\ 47^{\circ} 42^{\prime} 30^{\prime \prime} & 712 & -122^{\circ} 50^{\prime} 00^{\prime \prime} \\ 47^{\circ} 42^{\prime} 30^{\prime \prime} & 714 & -122^{\circ} 60^{\prime} 00^{\prime \prime} \\ 47^{\circ} 42 \cdot 30^{\prime \prime} & 716 & -122^{\circ} 45^{\prime} 00^{\prime \prime} \\ 47^{\circ} 37^{\prime} 30^{\prime \prime} & 718 & -122^{\circ} 55^{\prime} 00^{\prime \prime} \\ 47^{\circ} 37^{\prime} 30^{\prime \prime} & 720 & -123^{\circ} 05^{\prime} 00^{\prime \prime} \\ 47^{\circ} 32 \cdot 30^{\prime \prime} & 722 & -122^{\circ} 50^{\prime} 00^{\prime \prime} \\ 47^{\circ} 32^{\prime} 30^{\prime \prime} & 724 & -122^{\circ} 60^{\prime} 00^{\prime \prime} \\ 47^{\circ} 32^{\prime} 30^{\prime \prime} & & \end{array}$

$47^{\circ} 52 \cdot 30^{\prime \prime}$ $47^{\circ} 52^{\prime} 30^{\prime \prime}$ $47^{\circ} 47^{\prime} 30^{\prime \prime}$ $47^{\circ} 47^{\prime} 30^{\prime \prime}$ $47^{\circ} 47^{\prime} 30^{\prime \prime}$ $47^{\circ} 42^{\prime} 30^{\prime \prime}$ $47^{\circ} 42^{\prime} 30^{\prime \prime}$ $47^{\circ} 37^{\prime} 30^{\prime \prime}$ $47^{\circ} 37^{\prime} 30^{\prime \prime}$ $47^{\circ} 37^{\prime} 30^{\prime \prime}$ $47^{\circ} 32$ ' $30^{\prime \prime}$ $47^{\circ} 32^{\prime} 30^{\prime \prime}$ 


\begin{tabular}{|c|c|c|c|c|c|}
\hline Tic-ID & Longitude & Latitude & Tic-1D & Longitude & Latitude \\
\hline \multicolumn{6}{|c|}{ Recion 8: Tics 1-21 } \\
\hline 801 & $-122^{\circ} 12^{\prime} 30^{\prime \prime}$ & $47^{\circ} 55^{\prime} 00^{\prime \prime}$ & 802 & $-122^{\circ} 17^{\prime} 30^{\prime \prime}$ & $47^{\circ} 55^{\prime} 00^{\prime \prime}$ \\
\hline 803 & $-122^{\circ} 22^{\prime} 30^{\prime \prime}$ & $47^{\circ} 55^{\prime} 00^{\prime \prime}$ & 804 & $-122^{\circ} 27^{\prime} 30^{\prime \prime}$ & $47^{\circ} 55^{\prime} 00^{\prime \prime}$ \\
\hline 805 & $-122^{\circ} 32^{\prime} 30^{\prime \prime}$ & $47^{\circ} 55^{\prime} 00^{\prime \prime}$ & 806 & $-122^{\circ} 37^{\prime} 30^{\prime \prime}$ & $47^{\circ} 55^{\prime} 00^{\prime \prime}$ \\
\hline 807 & $-122^{\circ} 42^{\prime} 30^{\prime \prime}$ & $47^{\circ} 55^{\prime} 00^{\prime \prime}$ & 808 & $-122^{\circ} 12^{\prime} 30^{\prime \prime}$ & $47^{\circ} 50^{\prime} 00^{\prime \prime}$ \\
\hline 809 & $-122^{\circ} 17^{\prime} 30^{\prime \prime}$ & $47^{\circ} 50^{\prime} 00^{\prime \prime}$ & 810 & $-122^{\circ} 22^{\prime} 30^{\prime \prime}$ & $47^{\circ} 50^{\prime} 00^{\prime \prime}$ \\
\hline 811 & $-122^{\circ} 27^{\prime} 30^{\prime \prime}$ & $47^{\circ} 50^{\prime} 00^{\prime \prime}$ & 812 & $-122^{\circ} 32^{\prime} 30^{\prime \prime}$ & $47^{\circ} 50^{\prime} 00^{\prime \prime}$ \\
\hline 813 & $-122^{\circ} 37^{\prime} 30^{\prime \prime}$ & $47^{\circ} 50^{\prime} 00^{\prime \prime}$ & 814 & $-122^{\circ} 42^{\prime} 30^{\prime \prime}$ & $47^{\circ} 50^{\prime} 00^{\prime \prime}$ \\
\hline 815 & $-122^{\circ} 12^{\prime} 30^{\prime \prime}$ & $47^{\circ} 45^{\prime} 00^{\prime \prime}$ & 816 & $-122^{\circ} 17^{\prime} 30^{\prime \prime}$ & $47^{\circ} 45^{\prime} 00^{\prime \prime}$ \\
\hline 817 & $-122^{\circ} 22^{\prime} 30^{\prime \prime}$ & $47^{\circ} 45^{\prime} 00^{\prime \prime}$ & 818 & $-122^{\circ} 27^{\prime} 30^{\prime \prime}$ & $47^{\circ} 45^{\prime} 00^{\prime \prime}$ \\
\hline 819 & $-122^{\circ} 32^{\prime} 30^{\prime \prime}$ & $47^{\circ} 45^{\prime} 00^{\prime \prime}$ & 820 & $-122^{\circ} 37^{\prime} 30^{\prime \prime}$ & $47^{\circ} 45^{\prime} 00^{\prime \prime}$ \\
\hline 821 & $-122^{\circ} 42^{\prime} 30^{\prime \prime}$ & $47^{\circ} 45^{\prime} 00^{\prime \prime}$ & & & \\
\hline
\end{tabular}

\section{Region 9: Tics 1-21}

$\begin{array}{ll}901 & -122^{\circ} 15^{\prime} 00^{\prime \prime} \\ 903 & -122^{\circ} 25^{\prime} 00^{\prime \prime} \\ 905 & -122^{\circ} 35^{\prime} 00^{\prime \prime} \\ 907 & -122^{\circ} 45^{\prime} 00^{\prime \prime} \\ 909 & -122^{\circ} 20^{\prime} 00^{\prime \prime} \\ 911 & -122^{\circ} 30^{\prime} 00^{\prime \prime} \\ 913 & -122^{\circ} 40^{\prime} 00^{\prime \prime} \\ 915 & -122^{\circ} 15^{\prime} 00^{\prime \prime} \\ 917 & -122^{\circ} 25^{\prime} 00^{\prime \prime} \\ 919 & -122^{\circ} 35^{\prime} 00^{\prime \prime} \\ 921 & -122^{\circ} 45^{\prime} 00^{\prime \prime}\end{array}$

$\begin{array}{lll}47^{\circ} 42^{\prime} 30^{\prime \prime} & 902 & -122^{\circ} 20^{\prime} 00^{\prime \prime} \\ 47^{\circ} 42^{\prime} 30^{\prime \prime} & 904 & -122^{\circ} 30^{\prime} 00^{\prime \prime} \\ 47^{\circ} 42 \cdot 30^{\prime \prime} & 906 & -122^{\circ} 40^{\prime} 00^{\prime \prime} \\ 47^{\circ} 42 \cdot 30^{\prime \prime} & 908 & -122^{\circ} 15^{\prime} 00^{\prime \prime} \\ 47^{\circ} 37 \cdot 30^{\prime \prime} & 910 & -122^{\circ} 25^{\prime} 00^{\prime \prime} \\ 47^{\circ} 37 \cdot 30^{\prime \prime} & 912 & -122^{\circ} 35^{\prime} 00^{\prime \prime} \\ 47^{\circ} 37 \cdot 30^{\prime \prime} & 914 & -122^{\circ} 45^{\prime} 00^{\prime \prime} \\ 47^{\circ} 32 \cdot 30^{\prime \prime} & 916 & -122^{\circ} 20^{\prime} 00^{\prime \prime} \\ 47^{\circ} 32 \cdot 30^{\prime \prime} & 918 & -122^{\circ} 30^{\prime} 00^{\prime \prime} \\ 47^{\circ} 32 \cdot 30^{\prime \prime} & 920 & -122^{\circ} 40^{\prime} 00^{\prime \prime} \\ 47^{\circ} 32 \cdot 30^{\prime \prime} & & \end{array}$

$47^{\circ} 42^{\prime} 30^{\prime \prime}$ $47^{\circ} 42^{\prime} 30^{\prime \prime}$ $47^{\circ} 42^{\prime} 30^{\prime \prime}$ $47^{\circ} 37^{\prime} 30^{\prime \prime}$ $47^{\circ} 37^{\prime} 30^{\prime \prime}$ $47^{\circ} 37^{\prime} 30^{\prime \prime}$ $47^{\circ} 37^{\prime} 30^{\prime \prime}$ $47^{\circ} 32^{\prime} 30^{\prime \prime}$ $47^{\circ} 32^{\prime} 30^{\prime \prime}$ $47^{\circ} 32^{\prime} 30^{\prime \prime}$

\section{Reqion 10: Tics 1-21}

$\begin{array}{ll}1001 & -122^{\circ} 40^{\prime} 00^{\prime \prime} \\ 1003 & -122^{\circ} 50^{\prime} 00^{\prime \prime} \\ 1005 & -123^{\circ} 00^{\prime} 00^{\prime \prime} \\ 1007 & -123^{\circ} 10^{\prime} 00^{\prime \prime} \\ 1009 & -122^{\circ} 45^{\prime} 00^{\prime \prime} \\ 1011 & -122^{\circ} 55^{\prime} 00^{\prime \prime} \\ 1013 & -123^{\circ} 05^{\prime} 00^{\prime \prime} \\ 1015 & -122^{\circ} 40^{\prime} 00^{\prime \prime} \\ 1017 & -122^{\circ} 50^{\prime} 00^{\prime \prime} \\ 1019 & -123^{\circ} 00^{\prime} 00^{\prime \prime} \\ 1021 & -123^{\circ} 10^{\prime} 00^{\prime \prime}\end{array}$

$\begin{array}{lrr}47^{\circ} 27 \cdot 30^{\prime \prime} & 1002 & -122^{\circ} 45^{\prime} 00^{\prime \prime} \\ 47^{\circ} 27 \cdot 30^{\prime \prime} & 1004 & -122^{\circ} 55^{\prime} 00^{\prime \prime} \\ 47^{\circ} 27 \cdot 30^{\prime \prime} & 1006 & -123^{\circ} 05^{\prime} 00^{\prime \prime} \\ 47^{\circ} 27 \cdot 30^{\prime \prime} & 1008 & -122^{\circ} 40^{\prime} 00^{\prime \prime} \\ 47^{\circ} 22^{\prime} 30^{\prime \prime} & 1010 & -122^{\circ} 50^{\prime} 00^{\prime \prime} \\ 47^{\circ} 22^{\prime} 30^{\prime \prime} & 1012 & -123^{\circ} 00^{\prime} 00^{\prime \prime} \\ 47^{\circ} 22^{\prime} 30^{\prime \prime} & 1014 & -123^{\circ} 10^{\prime} 00^{\prime \prime} \\ 47^{\circ} 17 \cdot 30^{\prime \prime} & 1016 & -122^{\circ} 45^{\prime} 00^{\prime \prime} \\ 47^{\circ} 17 \cdot 30^{\prime \prime} & 1018 & -122^{\circ} 55^{\prime} 00^{\prime \prime} \\ 47^{\circ} 17 \cdot 30^{\prime \prime} & 1020 & -123^{\circ} 05^{\prime} 00^{\prime \prime} \\ 47^{\circ} 17^{\prime} 30^{\prime \prime} 30^{\prime \prime} & \end{array}$

$47^{\circ} 27^{\prime} 30^{\prime \prime}$ $47^{\circ} 27^{\prime} 30^{\prime \prime}$ $47^{\circ} 27^{\prime} 30^{\prime \prime}$ $47^{\circ} 22^{\prime} 30^{\prime \prime}$ $47^{\circ} 22^{\prime} 30^{\prime \prime}$ $47^{\circ} 22^{\prime} 30^{\prime \prime}$ $47^{\circ} 22^{\prime} 30^{\prime \prime}$ $47^{\circ} 17^{\prime} 30^{\prime \prime}$ $47^{\circ} 17^{\prime} 30^{\prime \prime}$ $47^{\circ} 17^{\prime} 30^{\prime \prime}$ 


\begin{tabular}{|c|c|c|c|c|c|}
\hline Tic-ID & Longitude & Latitude & Tic-ID & Longitude & Latitude \\
\hline \multicolumn{6}{|c|}{ Reqion 11: Tics 1-25 } \\
\hline 1101 & $-122^{\circ} 20^{\prime} 00^{\prime \prime}$ & $47^{\circ} 30^{\prime} 00^{\prime \prime}$ & 1102 & $-122^{\circ} 25^{\prime} 00^{\prime \prime}$ & $47^{\circ} 30^{\circ} 00^{\prime \prime}$ \\
\hline 1103 & $-122^{\circ} 30^{\prime} 00^{\prime \prime}$ & $47^{\circ} 30^{\prime} 00^{\prime \prime}$ & 1104 & $-122^{\circ} 35^{\prime} 00^{\prime \prime}$ & $47^{\circ} 30^{\prime} 00^{\prime \prime}$ \\
\hline 1105 & $-122^{\circ} 40^{\prime} 00^{\prime \prime}$ & $47^{\circ} 30^{\prime} 00^{\prime \prime}$ & 1106 & $-122^{\circ} 20^{\prime} 00^{\prime \prime}$ & $47^{\circ} 25^{\prime} 00^{\prime \prime}$ \\
\hline 1107 & $-122^{\circ} 25^{\prime} 00^{\prime \prime}$ & $47^{\circ} 25^{\prime} 00^{\prime \prime}$ & 1108 & $-122^{\circ} 30^{\prime} 00^{\prime \prime}$ & $47^{\circ} 25^{\prime} 00^{\prime \prime}$ \\
\hline 1109 & $-122^{\circ} 35^{\prime} 00^{\prime \prime}$ & $47^{\circ} 25^{\prime} 00^{\prime \prime}$ & 1110 & $-122^{\circ} 40^{\prime} 00^{\prime \prime}$ & $47^{\circ} 25^{\prime} 00^{\prime \prime}$ \\
\hline 1111 & $-122^{\circ} 20^{\prime} 00^{\prime \prime}$ & $47^{\circ} 20^{\prime} 00^{\prime \prime}$ & 1112 & $-122^{\circ} 25^{\prime} 00^{\prime \prime}$ & $47^{\circ} 20^{\prime} 00^{\prime \prime}$ \\
\hline 1113 & $-122^{\circ} 30^{\prime} 00^{\prime \prime}$ & $47^{\circ} 20^{\prime} 00^{\prime \prime}$ & 1114 & $-122^{\circ} 35^{\prime} 00^{\prime \prime}$ & $47^{\circ} 20^{\prime} 00^{\prime \prime}$ \\
\hline 1115 & $-122^{\circ} 40^{\prime} 00^{\prime \prime}$ & $47^{\circ} 20^{\prime} 00^{\prime \prime}$ & 1116 & $-122^{\circ} 20^{\prime} 00^{\prime \prime}$ & $47^{\circ} 15^{\prime} 00^{\prime \prime}$ \\
\hline 1117 & $-122^{\circ} 25^{\prime} 00^{\prime \prime}$ & $47^{\circ} 15^{\prime} 00^{\prime \prime}$ & 1118 & $-122^{\circ} 30^{\prime} 00^{\prime \prime}$ & $47^{\circ} 15^{\prime} 00^{\prime \prime}$ \\
\hline 1119 & $-122^{\circ} 35^{\prime} 00^{\prime \prime}$ & $47^{\circ} 15^{\prime} 00^{\prime \prime}$ & 1120 & $-122^{\circ} 40^{\prime} 00^{\prime \prime}$ & $47^{\circ} 15^{\prime} 00^{\prime \prime}$ \\
\hline 1121 & $-122^{\circ} 20^{\prime} 00^{\prime \prime}$ & $47^{\circ} 10^{\prime} 00^{\prime \prime}$ & 1122 & $-122^{\circ} 25^{\prime} 00^{\prime \prime}$ & $47^{\circ} 10^{\prime} 00^{\prime \prime}$ \\
\hline 1123 & $-122^{\circ} 30^{\prime} 00^{\prime \prime}$ & $47^{\circ} 10^{\prime} 00^{\prime \prime}$ & 1124 & $-122^{\circ} 35^{\prime} 00^{\prime \prime}$ & $47^{\circ} 10^{\prime} 00^{\prime \prime}$ \\
\hline 1125 & $-122^{\circ} 40^{\prime} 00^{\prime \prime}$ & $47^{\circ} 10^{\prime} 00^{\prime \prime}$ & & & \\
\hline \multicolumn{6}{|c|}{ Region 12: Tics 1-21 } \\
\hline 1201 & $-122^{\circ} 40^{\prime} 00^{\prime \prime}$ & $47^{\circ} 12^{\prime} 30^{\prime \prime}$ & 1202 & $-122^{\circ} 45^{\prime} 00^{\prime \prime}$ & $47^{\circ} 12^{\prime} 30^{\prime \prime}$ \\
\hline 1203 & $-122^{\circ} 50^{\prime} 00^{\prime \prime}$ & $47^{\circ} 12^{\prime} 30^{\prime \prime}$ & 1204 & $-122^{\circ} 55^{\prime} 00^{\prime \prime}$ & $47^{\circ} 12^{\prime} 30^{\prime \prime}$ \\
\hline 1205 & $-123^{\circ} 00^{\prime} 00^{\prime \prime}$ & $47^{\circ} 12^{\prime} 30^{\prime \prime}$ & 1206 & $-123^{\circ} 05^{\prime} 00^{\prime \prime}$ & $47^{\circ} 12^{\prime} 30^{\prime \prime}$ \\
\hline 1207 & $-123^{\circ} 10^{\prime} 00^{\prime \prime}$ & $47^{\circ} 12^{\prime} 30^{\prime \prime}$ & 1208 & $-122^{\circ} 40^{\prime} 00^{\prime \prime}$ & $47^{\circ} 07^{\prime} 30^{\prime \prime}$ \\
\hline 1209 & $-122^{\circ} 45^{\prime} 00^{\prime \prime}$ & $47^{\circ} 07^{\prime} 30^{\prime \prime}$ & 1210 & $-122^{\circ} 50^{\prime} 00^{\prime \prime}$ & $47^{\circ} 07^{\prime} 30^{\prime \prime}$ \\
\hline 1211 & $-122^{\circ} 55^{\prime} 00^{\prime \prime}$ & $47^{\circ} 07^{\prime} 30^{\prime \prime}$ & 1212 & $-123^{\circ} 00^{\prime} 00^{\prime \prime}$ & $47^{\circ} 07^{\prime} 30^{\prime \prime}$ \\
\hline 1213 & $-123^{\circ} 05^{\prime} 00^{\prime \prime}$ & $47^{\circ} 07^{\prime} 30^{\prime \prime}$ & 1214 & $-123^{\circ} 10^{\prime} 00^{\prime \prime}$ & $47^{\circ} 07^{\prime} 30^{\prime \prime}$ \\
\hline 1215 & $-122^{\circ} 40^{\prime} 00^{\prime \prime}$ & $47^{\circ} 02^{\prime} 30^{\prime \prime}$ & 1216 & $-122^{\circ} 45^{\prime} 00^{\prime \prime}$ & $47^{\circ} 02^{\prime} 30^{\prime \prime}$ \\
\hline 1217 & $-122^{\circ} 50^{\prime} 00^{\prime \prime}$ & $47^{\circ} 02^{\prime} 30^{\prime \prime}$ & 1218 & $-122^{\circ} 55^{\prime} 00^{\prime \prime}$ & $47^{\circ} 02^{\prime} 30^{\prime \prime}$ \\
\hline 1219 & $-123^{\circ} 00^{\prime} 00^{\prime \prime}$ & $47^{\circ} 02 \cdot 30^{\prime \prime}$ & 1220 & $-123^{\circ} 05^{\prime} 00^{\prime \prime}$ & $47^{\circ} 02^{\prime} 30^{\prime \prime}$ \\
\hline 1221 & $-123^{\circ} 10^{\prime} 00^{\prime \prime}$ & $47^{\circ} 02 \cdot 30^{\prime \prime}$ & & & \\
\hline
\end{tabular}




\section{APPENDIX D}

\section{Root-Mean-Square Error \\ for Base and Extra Drawing Interchange Format File Conversion}

[input units $=$ millimeters; output units $=$ meters $]$

Region 1

Scale $(X, Y)=(1000.442,1001.797)$ Translation $=(506844.454,5409831.637)$

Rotation (degrees) $=(0.009)$ RMS Error (input, output) $=(0.027,27.073)$

\begin{tabular}{|c|c|c|c|c|}
\hline Tic-ID & $\begin{array}{l}\text { input } x \\
\text { output } y\end{array}$ & $\begin{array}{l}\text { input y } \\
\text { output y }\end{array}$ & $x$ error & y error \\
\hline \multirow[t]{2}{*}{101} & 17.565 & 8.190 & & \\
\hline & 524419.625 & 5418030.000 & -3.334 & -9.172 \\
\hline \multirow[t]{2}{*}{102} & 11.479 & 8.179 & & \\
\hline & 518316.688 & 5418007.000 & 10.466 & 8.633 \\
\hline \multirow[t]{2}{*}{103} & 5.371 & 8.169 & & \\
\hline & 512213.812 & 5417990.000 & 2.938 & 20.420 \\
\hline \multirow[t]{2}{*}{104} & -0.733 & 8.158 & & \\
\hline & 506103.000 & 5417980.000 & 7.272 & 25.211 \\
\hline \multirow[t]{2}{*}{105} & -6.820 & 8.148 & & \\
\hline & 500000.000 & 5417977.000 & 19.834 & 23.015 \\
\hline \multirow[t]{2}{*}{106} & -12.937 & 8.137 & & \\
\hline & 493897.000 & 5417980.000 & 3.746 & 14.794 \\
\hline \multirow[t]{2}{*}{107} & -19.056 & 8.127 & & \\
\hline & 487786.312 & 5417990.000 & -7.915 & -0.429 \\
\hline \multirow[t]{2}{*}{108} & -25.182 & 8.116 & & \\
\hline & 481683.312 & 5418007.000 & -33.046 & -22.657 \\
\hline \multirow[t]{2}{*}{109} & 17.583 & -1.074 & & \\
\hline & 524460.312 & 5408760.000 & -25.316 & -19.898 \\
\hline \multirow[t]{2}{*}{110} & 11.509 & -1.088 & & \\
\hline & 518347.188 & 5408736.000 & 11.072 & -4.539 \\
\hline \multirow[t]{2}{*}{111} & 5.393 & -1.102 & & \\
\hline & 512234.094 & 5408720.000 & 5.534 & 2.760 \\
\hline \multirow[t]{2}{*}{112} & -0.722 & -1.116 & & \\
\hline & 506113.094 & 5408710.000 & 9.704 & 4.062 \\
\hline
\end{tabular}




\section{Region 1 - Continued}

Scale $(X, Y)=(1000.442,1001.797)$ Translation $=(506844.454,5409831.637)$

Rotation (degrees) $=(0.009)$ RMS Error (input, output) $=(0.027,27.073)$

\begin{tabular}{|c|c|c|c|c|}
\hline Tic-1D & $\begin{array}{l}\text { input } x \\
\text { output } x\end{array}$ & $\begin{array}{l}\text { input y } \\
\text { output } y\end{array}$ & $x$ error & y error \\
\hline \multirow[t]{2}{*}{113} & -6.828 & -1.130 & & \\
\hline & 500000.000 & 5408706.000 & 13.541 & -0.625 \\
\hline \multirow[t]{2}{*}{114} & -12.950 & -1.144 & & \\
\hline & 493886.906 & 5408710.000 & 1.838 & -13.335 \\
\hline \multirow[t]{2}{*}{115} & -19.071 & -1.158 & & \\
\hline & 487765.906 & 5408720.000 & -0.513 & -32.042 \\
\hline \multirow[t]{2}{*}{116} & -25.197 & -1.172 & & \\
\hline & 481652.812 & 5408736.000 & -15.922 & -56.757 \\
\hline \multirow[t]{2}{*}{117} & 17.600 & -10.339 & & \\
\hline & 524500.812 & 5399500.000 & -47.109 & -41.236 \\
\hline \multirow[t]{2}{*}{118} & 11.538 & -10.340 & & \\
\hline & 518377.594 & 5399476.000 & 11.720 & -13.393 \\
\hline \multirow[t]{2}{*}{119} & 5.414 & -10.342 & & \\
\hline & 512254.312 & 5399460.000 & 8.115 & 6.490 \\
\hline \multirow[t]{2}{*}{120} & -0.711 & -10.343 & & \\
\hline & 506123.312 & 5399450.000 & 11.948 & 20.373 \\
\hline \multirow[t]{2}{*}{121} & -6.836 & -10.345 & & \\
\hline & 500000.000 & 5399446.000 & 7.290 & 28.256 \\
\hline \multirow[t]{2}{*}{122} & -12.964 & -10.346 & & \\
\hline & 493876.812 & 5399450.000 & 0.032 & 28.141 \\
\hline \multirow[t]{2}{*}{123} & -19.085 & -10.348 & & \\
\hline & 487745.688 & 5399460.000 & 6.836 & 22.022 \\
\hline \multirow[t]{2}{*}{124} & -25.211 & -10.349 & & \\
\hline & 481622.406 & 5399476.000 & 1.269 & 9.906 \\
\hline
\end{tabular}




\section{Reaion 2}

Scale $(X, Y)=(1000.068,999.768)$ Translation $=(513833.598,5379804.531)$

Rotation (degrees) $=(0.012)$ RMS Error (input, output) $=(0.037,36.650)$

\begin{tabular}{|c|c|c|c|c|}
\hline TIC-ID & $\begin{array}{l}\text { Input } x \\
\text { output } x\end{array}$ & $\begin{array}{l}\text { Input y } \\
\text { output y }\end{array}$ & $x$ error & y error \\
\hline \multirow[t]{2}{*}{201} & 29.045 & 19.755 & & \\
\hline & 542878.312 & 5399610.000 & -2.238 & -60.944 \\
\hline \multirow[t]{2}{*}{202} & 22.912 & 19.743 & & \\
\hline & 536755.125 & 5399567.000 & -11.846 & -28.677 \\
\hline \multirow[t]{2}{*}{203} & 16.790 & 19.731 & & \\
\hline & 530631.875 & 5399530.000 & -10.863 & -2.392 \\
\hline \multirow[t]{2}{*}{204} & 10.664 & 19.719 & & \\
\hline & 524500.812 & 5399500.000 & -6.312 & 16.885 \\
\hline \multirow[t]{2}{*}{205} & 4.540 & 19.707 & & \\
\hline & 518377.594 & 5399476.000 & -7.255 & 30.167 \\
\hline \multirow[t]{2}{*}{206} & -1.583 & 19.695 & & \\
\hline & 512254.312 & 5399460.000 & -8.039 & 35.448 \\
\hline \multirow[t]{2}{*}{207} & -7.628 & 19.683 & & \\
\hline & 506123.312 & 5399450.000 & 77.296 & 34.867 \\
\hline \multirow[t]{2}{*}{208} & -13.836 & 19.671 & & \\
\hline & 500000.000 & 5399446.000 & -7.498 & 28.002 \\
\hline \multirow[t]{2}{*}{209} & -19.962 & 19.659 & & \\
\hline & 493876.812 & 5399450.000 & -10.242 & 13.281 \\
\hline \multirow[t]{2}{*}{210} & -26.087 & 19.647 & & \\
\hline & 487745.688 & 5399460.000 & -4.831 & -7.441 \\
\hline \multirow[t]{2}{*}{211} & -32.213 & 19.635 & & \\
\hline & 481622.406 & 5399476.000 & -8.005 & -34.163 \\
\hline \multirow[t]{2}{*}{212} & 29.116 & 10.495 & & \\
\hline & 542949.125 & 5390351.000 & -0.166 & -60.153 \\
\hline \multirow[t]{2}{*}{213} & 22.974 & 10.479 & & \\
\hline & 536815.812 & 5390307.000 & -9.204 & -30.177 \\
\hline \multirow[t]{2}{*}{214} & 16.840 & 10.464 & & \\
\hline & 530682.375 & 5390270.000 & -9.277 & -7.180 \\
\hline \multirow[t]{2}{*}{215} & 10.706 & 10.449 & & \\
\hline & 524541.312 & 5390240.000 & -3.324 & 8.812 \\
\hline
\end{tabular}




\section{Region 2 -Continued}

Scale $(X, Y)=(1000.068,999.768)$ Translation $=(513833.598,5379804.531)$

Rotation (degrees) $=(0.012)$ RMS Error $($ input, output) $=(0.037,36.650)$

\begin{tabular}{|c|c|c|c|c|}
\hline TIC-1D & $\begin{array}{l}\text { input } x \\
\text { output } x\end{array}$ & $\begin{array}{l}\text { input y } \\
\text { output y }\end{array}$ & $x$ error & y error \\
\hline \multirow[t]{2}{*}{216} & 4.572 & 10.434 & & \\
\hline & 518407.906 & 5390217.000 & -4.608 & 17.806 \\
\hline \multirow[t]{2}{*}{217} & -1.563 & 10.418 & & \\
\hline & 512274.594 & 5390200.000 & -6.711 & 20.798 \\
\hline \multirow[t]{2}{*}{218} & -7.638 & 10.403 & & \\
\hline & 506133.312 & 5390190.000 & 59.400 & 16.927 \\
\hline \multirow[t]{2}{*}{219} & -13.836 & 10.388 & & \\
\hline & 500000.000 & 5390187.000 & -5.166 & 5.776 \\
\hline \multirow[t]{2}{*}{220} & -19.972 & 10.373 & & \\
\hline & 493866.688 & 5390190.000 & -8.359 & -11.234 \\
\hline \multirow[t]{2}{*}{221} & -26.108 & 10.357 & & \\
\hline & 487725.406 & 5390200.000 & -3.897 & -35.245 \\
\hline \multirow[t]{2}{*}{222} & -32.246 & 10.342 & & \\
\hline & 481592.094 & 5390217.000 & -8.647 & -66.259 \\
\hline \multirow[t]{2}{*}{223} & 29.187 & 1.228 & & \\
\hline & 543019.875 & 5381081.000 & 2.016 & -54.319 \\
\hline \multirow[t]{2}{*}{224} & 23.035 & 1.215 & & \\
\hline & 536876.500 & 5381037.000 & -6.561 & -21.962 \\
\hline \multirow[t]{2}{*}{225} & 16.891 & 1.203 & & \\
\hline & 530733.125 & 5381000.000 & -7.971 & 3.409 \\
\hline \multirow[t]{2}{*}{226} & 10.747 & 1.190 & & \\
\hline & 524581.688 & 5380970.000 & -0.263 & 21.782 \\
\hline \multirow[t]{2}{*}{227} & 4.603 & 1.177 & & \\
\hline & 518438.312 & 5380947.000 & -2.113 & 33.152 \\
\hline \multirow[t]{2}{*}{228} & -1.544 & 1.164 & & \\
\hline & 512294.812 & 5380930.000 & -5.372 & 38.519 \\
\hline \multirow[t]{2}{*}{229} & -7.648 & 1.151 & & \\
\hline & 506143.500 & 5380920.000 & 41.341 & 36.966 \\
\hline \multirow[t]{2}{*}{230} & -13.835 & 1.138 & & \\
\hline & 500000.000 & 5380916.000 & -2.843 & 29.256 \\
\hline
\end{tabular}




\section{Region 2-Continued}

Scale $(X, Y)=(1000.068,999.768)$ Translation $=(513833.598,5379804.531)$

Rotation (degrees) $=(0.012)$ RMS Error (input, output) $=(0.037,36.650)$

\begin{tabular}{|c|c|c|c|c|}
\hline Tic-ID & $\begin{array}{l}\text { input } x \\
\text { output } x\end{array}$ & $\begin{array}{l}\text { input y } \\
\text { output y }\end{array}$ & $x$ error & y error \\
\hline \multirow[t]{2}{*}{231} & -19.982 & 1.125 & & \\
\hline & 493856.500 & 5380920.000 & -6.379 & 13.623 \\
\hline \multirow[t]{2}{*}{232} & -26.129 & 1.112 & & \\
\hline & 487705.188 & 5380930.000 & -2.931 & -8.012 \\
\hline \multirow[t]{2}{*}{233} & -32.279 & 1.100 & & \\
\hline & 481561.812 & 5380947.000 & -9.152 & -36.650 \\
\hline \multirow[t]{2}{*}{234} & 29.257 & -8.017 & & \\
\hline & 543090.625 & 5371821.000 & 4.028 & -37.013 \\
\hline \multirow[t]{2}{*}{235} & 23.096 & -8.030 & & \\
\hline & 536937.125 & 5371778.000 & -3.981 & -6.301 \\
\hline \multirow[t]{2}{*}{236} & 16.941 & -8.044 & & \\
\hline & 530783.500 & 5371741.000 & -6.376 & 18.422 \\
\hline \multirow[t]{2}{*}{237} & 10.789 & -8.057 & & \\
\hline & 524622.125 & 5371710.000 & 2.678 & 37.153 \\
\hline \multirow[t]{2}{*}{238} & 4.633 & -8.071 & & \\
\hline & 518468.500 & 5371687.000 & 0.567 & 47.876 \\
\hline \multirow[t]{2}{*}{239} & -1.524 & -8.084 & & \\
\hline & 512315.000 & 5371670.000 & -4.016 & 52.595 \\
\hline \multirow[t]{2}{*}{240} & -7.658 & -8.098 & & \\
\hline & 506153.594 & 5371660.000 & 23.378 & 50.362 \\
\hline \multirow[t]{2}{*}{241} & -13.835 & -8.111 & & \\
\hline & 500000.000 & 5371657.000 & -0.520 & 41.043 \\
\hline \multirow[t]{2}{*}{242} & -19.992 & -8.125 & & \\
\hline & 493846.406 & 5371660.000 & -4.494 & 25.763 \\
\hline \multirow[t]{2}{*}{243} & -26.150 & -8.138 & & \\
\hline & 487685.000 & 5371670.000 & -2.009 & 3.480 \\
\hline \multirow[t]{2}{*}{244} & -32.311 & -8.152 & & \\
\hline & 481531.500 & 5371687.000 & -9.654 & -25.807 \\
\hline \multirow[t]{2}{*}{245} & 29.328 & -17.280 & & \\
\hline & 543161.125 & 5362562.000 & 6.438 & -39.518 \\
\hline
\end{tabular}




\section{Region 2-Continued}

Scale $(X, Y)=(1000.068,999.768)$ Translation $=(513833.598,5379804.531)$

Rotation (degrees) $=(0.012)$ RMS Error (input, output) $=(0.037,36.650)$

\begin{tabular}{|c|c|c|c|c|}
\hline Tic-ID & $\begin{array}{l}\text { input } x \\
\text { output } x\end{array}$ & $\begin{array}{l}\text { input y } \\
\text { output y }\end{array}$ & $x$ error & y error \\
\hline \multirow[t]{2}{*}{246} & 23.158 & -17.300 & & \\
\hline & 536997.500 & 5362518.000 & -0.985 & -13.813 \\
\hline \multirow[t]{2}{*}{247} & 16.991 & -17.319 & & \\
\hline & 530833.875 & 5362481.000 & -4.616 & 4.904 \\
\hline \multirow[t]{2}{*}{248} & 10.830 & -17.339 & & \\
\hline & 524662.375 & 5362451.000 & 5.970 & 16.640 \\
\hline \multirow[t]{2}{*}{249} & 4.665 & -17.358 & & \\
\hline & 518498.812 & 5362428.000 & 3.265 & 21.360 \\
\hline \multirow[t]{2}{*}{250} & -1.504 & -17.378 & & \\
\hline & 512335.188 & 5362411.000 & -2.554 & 20.070 \\
\hline \multirow[t]{2}{*}{251} & -7.668 & -17.397 & & \\
\hline & 506163.594 & 5362401.000 & 5.466 & 11.798 \\
\hline \multirow[t]{2}{*}{252} & -13.834 & -17.417 & & \\
\hline & 500000.000 & 5362398.000 & 1.817 & -3.485 \\
\hline \multirow[t]{2}{*}{253} & -20.002 & -17.436 & & \\
\hline & 493836.406 & 5362401.000 & -2.758 & -24.771 \\
\hline \multirow[t]{2}{*}{254} & -26.172 & -17.456 & & \\
\hline & 487664.812 & 5362411.000 & -1.226 & -53.063 \\
\hline \multirow[t]{2}{*}{255} & -32.344 & -17.475 & & \\
\hline & 481501.188 & 5362428.000 & -10.398 & $-88 \cdot 362$ \\
\hline
\end{tabular}


Region 3

Scale $(X, Y)=(1000.356,995.358)$ Translation $=(486840.646,5336832.782)$

Rotation (degrees) $=(0.034)$ RMS Error (input, output) $=(0.031,30.897)$

\begin{tabular}{|c|c|c|c|c|}
\hline Tic-ID & $\begin{array}{l}\text { input } x \\
\text { output } x\end{array}$ & $\begin{array}{l}\text { input y } \\
\text { output y }\end{array}$ & $x$ error & y error \\
\hline \multirow[t]{2}{*}{301} & -20.780 & 21.146 & & \\
\hline & 466060.500 & 5357864.000 & -20.013 & -29.817 \\
\hline \multirow[t]{2}{*}{302} & -14.608 & 21.116 & & \\
\hline & 472229.188 & 5357831.000 & -14.008 & -12.993 \\
\hline \multirow[t]{2}{*}{303} & -8.409 & 21.086 & & \\
\hline & 478397.812 & 5357804.000 & 18.694 & -2.238 \\
\hline \multirow[t]{2}{*}{304} & -2.206 & 21.055 & & \\
\hline & 484574.406 & 5357784.000 & 46.771 & 1.507 \\
\hline \multirow[t]{2}{*}{305} & 3.892 & 21.026 & & \\
\hline & 490743.000 & 5357770.000 & -20.889 & -0.475 \\
\hline \multirow[t]{2}{*}{306} & 10.085 & 20.995 & & \\
\hline & 496911.688 & 5357763.000 & 4.797 & -9.702 \\
\hline \multirow[t]{2}{*}{307} & 16.232 & 20.965 & & \\
\hline & 503088.312 & 5357763.000 & -22.154 & -25.812 \\
\hline \multirow[t]{2}{*}{308} & 22.427 & 20.935 & & \\
\hline & 509257.000 & 5357770.000 & 6.531 & -49.048 \\
\hline \multirow[t]{2}{*}{309} & -20.834 & 11.877 & & \\
\hline & 466005.188 & 5348605.000 & -12.863 & 3.117 \\
\hline \multirow[t]{2}{*}{310} & -14.653 & 11.847 & & \\
\hline & 472183.906 & 5348571.000 & -8.786 & 20.998 \\
\hline \multirow[t]{2}{*}{311} & -8.453 & 11.817 & & \\
\hline & 478362.594 & 5348545.000 & 14.745 & 30.828 \\
\hline \multirow[t]{2}{*}{312} & -2.254 & 11.787 & & \\
\hline & 484549.312 & 5348524.000 & 30.040 & 35.659 \\
\hline \multirow[t]{2}{*}{313} & 3.882 & 11.757 & & \\
\hline & 490728.000 & 5348511.000 & -10.780 & 32.656 \\
\hline \multirow[t]{2}{*}{314} & 10.069 & 11.727 & & \\
\hline & 496906.688 & 5348504.000 & -0.638 & 23.522 \\
\hline \multirow[t]{2}{*}{315} & 16.233 & 11.696 & & \\
\hline & 503093.312 & 5348504.000 & -20.319 & 7.444 \\
\hline
\end{tabular}


Scale $(X, Y)=(1000.356,995.358)$ Translation $=(486840.646,5336832.782)$

Rotation (degrees) $=(0.034)$ RMS Error (input, output) $=(0.031,30.897)$

\begin{tabular}{|c|c|c|c|c|}
\hline Tic-ID & $\begin{array}{l}\text { input } x \\
\text { output } x\end{array}$ & $\begin{array}{l}\text { input y } \\
\text { output y }\end{array}$ & $x$ error & y error \\
\hline \multirow[t]{2}{*}{316} & 22.439 & 11.666 & & \\
\hline & 509272.000 & 5348511.000 & 9.076 & -15.741 \\
\hline \multirow[t]{2}{*}{317} & -20.888 & 2.511 & & \\
\hline & 465949.906 & 5339335.000 & -6.250 & -49.845 \\
\hline \multirow[t]{2}{*}{318} & -14.699 & 2.495 & & \\
\hline & 472138.594 & 5339302.000 & -3.891 & -18.813 \\
\hline \multirow[t]{2}{*}{319} & -8.498 & 2.479 & & \\
\hline & 478327.406 & 5339275.000 & 10.472 & 6.215 \\
\hline \multirow[t]{2}{*}{320} & -2.301 & 2.463 & & \\
\hline & 484524.094 & 5339255.000 & 13.187 & 24.244 \\
\hline \multirow[t]{2}{*}{321} & 3.872 & 2.447 & & \\
\hline & 490712.906 & 5339241.000 & -0.598 & 36.281 \\
\hline \multirow[t]{2}{*}{322} & 10.053 & 2.431 & & \\
\hline & 496901.688 & 5339235.000 & -6.103 & 40.315 \\
\hline \multirow[t]{2}{*}{323} & 16.235 & 2.415 & & \\
\hline & 503098.312 & 5339235.000 & -18.475 & 38.349 \\
\hline \multirow[t]{2}{*}{324} & 22.451 & 2.399 & & \\
\hline & 509287.094 & 5339241.000 & 11.524 & 30.372 \\
\hline \multirow[t]{2}{*}{325} & -20.942 & -6.757 & & \\
\hline & 465894.688 & 5330077.000 & 0.810 & -17.025 \\
\hline \multirow[t]{2}{*}{326} & -14.745 & -6.791 & & \\
\hline & 472093.500 & 5330043.000 & 1.072 & -2.550 \\
\hline \multirow[t]{2}{*}{327} & -8.543 & -6.824 & & \\
\hline & 478292.312 & 5330016.000 & 6.252 & 4.910 \\
\hline \multirow[t]{2}{*}{328} & -2.349 & -6.858 & & \\
\hline & 484499.000 & 5329996.000 & -3.779 & 5.393 \\
\hline \multirow[t]{2}{*}{329} & 3.861 & -6.892 & & \\
\hline & 490697.812 & 5329983.000 & 9.568 & -1.173 \\
\hline \multirow[t]{2}{*}{330} & 10.037 & -6.925 & & \\
\hline & 496896.594 & 5329976.000 & -11.543 & -13.630 \\
\hline \multirow[t]{2}{*}{331} & 16.236 & -6.959 & & \\
\hline & 503103.406 & 5329976.000 & -16.657 & -33.163 \\
\hline \multirow[t]{2}{*}{332} & 22.464 & -6.993 & & \\
\hline & 509302.188 & 5329983.000 & 14.208 & -59.784 \\
\hline
\end{tabular}




\section{Region 4}

Scale $(X, Y)=(1.000,1.000)$ Translation $=(-308.519,842.465)$

Rotation (degrees) $=(0.003)$ RMS Error (input, output) $=(12.175,12.174)$

\begin{tabular}{|c|c|c|c|c|}
\hline Tic-ID & $\begin{array}{l}\text { Input } x \\
\text { output } x\end{array}$ & $\begin{array}{l}\text { input y } \\
\text { output y }\end{array}$ & $x$ error & y error \\
\hline \multirow[t]{2}{*}{401} & 546284.631 & 5357941.560 & & \\
\hline & 546284.688 & 5357951.000 & 1.170 & -16.302 \\
\hline \multirow[t]{2}{*}{402} & 540111.132 & 5357912.996 & & \\
\hline & 540116.125 & 5357904.000 & -3.680 & 0.849 \\
\hline \multirow[t]{2}{*}{403} & 533940.996 & 5357884.447 & & \\
\hline & 533939.500 & 5357864.000 & 2.895 & 11.017 \\
\hline \multirow[t]{2}{*}{404} & 527769.402 & 5357855.892 & & \\
\hline & 527770.875 & 5357831.000 & 0.011 & 14.178 \\
\hline \multirow[t]{2}{*}{405} & 521598.832 & 5357827.342 & & \\
\hline & 521602.188 & 5357804.000 & -1.785 & 11.344 \\
\hline \multirow[t]{2}{*}{406} & 515426.812 & 5357798.785 & & \\
\hline & 515425.594 & 5357784.000 & 2.875 & 1.503 \\
\hline \multirow[t]{2}{*}{407} & 509253.751 & 5357770.743 & & \\
\hline & 509257.000 & 5357770.000 & -1.507 & -13.824 \\
\hline \multirow[t]{2}{*}{408} & 546360.945 & 5348677.052 & & \\
\hline & 546360.125 & 5348692.000 & 1.497 & -20.128 \\
\hline \multirow[t]{2}{*}{409} & 540177.362 & 5348648.443 & & \\
\hline & 540181.375 & 5348645.000 & -3.250 & -3.024 \\
\hline \multirow[t]{2}{*}{410} & 533996.258 & 5348619.845 & & \\
\hline & 533994.812 & 5348605.000 & 2.294 & 7.093 \\
\hline \multirow[t]{2}{*}{411} & 527814.579 & 5348591.245 & . & \\
\hline & 527816.125 & 5348571.000 & -0.611 & 11.206 \\
\hline \multirow[t]{2}{*}{412} & 521634.800 & 5348562.653 & & \\
\hline & 521637.406 & 5348545.000 & -1.586 & 7.329 \\
\hline \multirow[t]{2}{*}{413} & 515453.122 & 5348534.053 & & \\
\hline & 515450.812 & 5348524.000 & 3.416 & -1.557 \\
\hline \multirow[t]{2}{*}{414} & 509269.089 & 5348505.442 & & \\
\hline & 509272.000 & 5348511.000 & -1.718 & -18.455 \\
\hline \multirow[t]{2}{*}{415} & 546437.264 & 5339412.063 & & \\
\hline & 546435.625 & 5339423.000 & 1.765 & -14.436 \\
\hline
\end{tabular}




\section{Region 4 Continued}

Scale $(X, Y)=(1.000,1.000)$ Translation $=(-308.519,842.465)$

Rotation (degrees) $=(0.003)$ RMS Error (input, output) $=(12.175,12.174)$

\begin{tabular}{lllll}
\hline Tic-ID & $\begin{array}{l}\text { input } x \\
\text { output } x\end{array}$ & $\begin{array}{l}\text { input } y \\
\text { output } y\end{array}$ & x error & y error \\
\hline \multirow{2}{*}{416} & 540243.600 & 5339382.850 & & \\
& 540246.812 & 5339376.000 & -3.000 & 2.063 \\
417 & 534051.529 & 5339353.645 & & \\
& 534050.125 & 5339335.000 & 1.703 & 12.570 \\
418 & 527859.767 & 5339324.441 & & 15.078 \\
& 527861.375 & 5339302.000 & -1.223 & \\
419 & 521670.778 & 5339295.250 & & 11.600 \\
420 & 521672.594 & 5339275.000 & -1.345 & \\
& 515479.440 & 5339266.049 & & \\
421 & 515475.906 & 5339255.000 & 4.091 & -19.214
\end{tabular}




\section{Region 5}

Scale $(X, Y)=(1002.545,1001.556)$ Translation $=(6386.976,-7976.827)$

Rotation (degrees) $=(0.083)$ RMS Error (input, output) $=(0.053,53.224)$

\begin{tabular}{|c|c|c|c|c|}
\hline Tic-ID & $\begin{array}{l}\text { input } x \\
\text { output } x\end{array}$ & $\begin{array}{l}\text { input y } \\
\text { output y }\end{array}$ & x error & y error \\
\hline \multirow[t]{2}{*}{501} & 534.081 & 5334.714 & & \\
\hline & 534077.688 & 5334711.000 & 14.929 & -8.104 \\
\hline \multirow[t]{2}{*}{502} & 527.883 & 5334.689 & & \\
\hline & 527883.875 & 5334678.000 & -4.967 & 3.364 \\
\hline \multirow[t]{2}{*}{503} & 521.688 & 5334.663 & & \\
\hline & 521690.188 & 5334651.000 & -21.999 & 8.843 \\
\hline \multirow[t]{2}{*}{504} & 515.490 & 5334.638 & & \\
\hline & 515488.406 & 5334631.000 & -33.214 & 7.314 \\
\hline \multirow[t]{2}{*}{505} & 509.295 & 5334.613 & & \\
\hline & 509294.688 & 5334617.000 & -50.862 & -0.210 \\
\hline \multirow[t]{2}{*}{506} & 503.098 & 5334.587 & & \\
\hline & 503100.906 & 5334611.000 & -69.443 & -15.737 \\
\hline \multirow[t]{2}{*}{507} & 497.147 & 5334.563 & & \\
\hline & 496899.094 & 5334611.000 & 165.741 & -36.412 \\
\hline \multirow[t]{2}{*}{508} & 534.136 & 5325.456 & & \\
\hline & 534132.875 & 5325442.000 & 28.987 & -11.557 \\
\hline \multirow{2}{*}{509} & 527.928 & 5325.437 & & \\
\hline & 527929.125 & 5325408.000 & 8.837 & 7.688 \\
\hline \multirow[t]{2}{*}{510} & 521.723 & 5325.419 & & \\
\hline & 521725.312 & 5325381.000 & -8.245 & 19.941 \\
\hline \multirow[t]{2}{*}{511} & 515.516 & 5325.400 & & \\
\hline & 515513.500 & 5325361.000 & -19.595 & 25.188 \\
\hline \multirow[t]{2}{*}{512} & 509.310 & 5325.382 & & \\
\hline & 509309.688 & 5325348.000 & -37.296 & 23.439 \\
\hline \multirow[t]{2}{*}{513} & 503.103 & 5325.363 & & \\
\hline & 503105.906 & 5325341.000 & -56.015 & 15.688 \\
\hline \multirow[t]{2}{*}{514} & 497.046 & 5325.345 & & \\
\hline & 496894.094 & 5325341.000 & 83.183 & 1.292 \\
\hline \multirow[t]{2}{*}{515} & 534.192 & 5316.193 & & \\
\hline & 534188.000 & 5316183.000 & 43.143 & -29.860 \\
\hline
\end{tabular}




\section{Region 5 -Continued}

Scale $(X, Y)=(1002.545,1001.556)$ Translation $=(6386.976,-7976.827)$

Rotation (degrees) $=(0.083)$ RMS Error (input, output) $=(0.053,53.224)$

\begin{tabular}{|c|c|c|c|c|}
\hline Tic-1D & $\begin{array}{l}\text { input } x \\
\text { output } x\end{array}$ & $\begin{array}{l}\text { input y } \\
\text { output y }\end{array}$ & $x$ error & y error \\
\hline \multirow[t]{2}{*}{516} & 527.974 & 5316.175 & & \\
\hline & 527974.188 & 5316150.000 & 22.899 & -11.189 \\
\hline \multirow[t]{2}{*}{517} & 521.758 & 5316.157 & & \\
\hline & 521760.312 & 5316123.000 & 5.726 & 1.489 \\
\hline \multirow[t]{2}{*}{518} & 515.541 & 5316.139 & & \\
\hline & 515538.594 & 5316103.000 & -5.877 & 7.162 \\
\hline \multirow[t]{2}{*}{519} & 509.325 & 5316.120 & & \\
\hline & 509324.688 & 5316089.000 & -23.637 & 6.838 \\
\hline \multirow[t]{2}{*}{520} & 503.108 & 5316.102 & & \\
\hline & 503110.906 & 5316082.000 & -42.514 & -0.487 \\
\hline \multirow[t]{2}{*}{521} & 496.945 & 5316.084 & & \\
\hline & 496889.094 & 5316082.000 & 0.219 & -14.690 \\
\hline
\end{tabular}




\section{Region 6}

Scale $(X, Y)=(1003.621,1000.530)$ Translation $=(4007.221,-3149.250)$

Rotation (degrees) $=(0.065)$ RMS Error $($ input, output $)=(0.043,43.030)$

\begin{tabular}{|c|c|c|c|c|}
\hline TIC-1D & $\begin{array}{l}\text { input } x \\
\text { output } x\end{array}$ & $\begin{array}{l}\text { input y } \\
\text { output y }\end{array}$ & $x$ error & y error \\
\hline 601 & $\begin{array}{l}561.857 \\
561861.125\end{array}$ & $\begin{array}{l}5344.185 \\
5344204.000\end{array}$ & -1.699 & 3.051 \\
\hline 602 & $\begin{array}{l}555.681 \\
555677.375\end{array}$ & $\begin{array}{l}5344.135 \\
5344140.000\end{array}$ & -16.611 & 13.563 \\
\hline 603 & $\begin{array}{l}549.490 \\
549493.688\end{array}$ & $\begin{array}{l}5344.086 \\
5344083.000\end{array}$ & -45.960 & 16.950 \\
\hline 604 & $\begin{array}{l}543.308 \\
543302.125\end{array}$ & $\begin{array}{l}5344.036 \\
5344033.000\end{array}$ & -58.993 & 13.411 \\
\hline 605 & $\begin{array}{l}537.328 \\
537118.312\end{array}$ & $\begin{array}{l}5343.988 \\
5343989.000\end{array}$ & 123.201 & 5.622 \\
\hline 606 & $\begin{array}{l}561.958 \\
561961.375\end{array}$ & $\begin{array}{l}5334.895 \\
5334945.000\end{array}$ & 10.039 & -33.095 \\
\hline 607 & $\begin{array}{l}555.770 \\
555767.812\end{array}$ & $\begin{array}{l}5334.852 \\
5334882.000\end{array}$ & -7.287 & -17.139 \\
\hline 608 & $\begin{array}{l}549.570 \\
549574.000\end{array}$ & $\begin{array}{l}5334.808 \\
5334825.000\end{array}$ & -35.568 & -7.268 \\
\hline 609 & $\begin{array}{l}543.376 \\
543372.312\end{array}$ & $\begin{array}{l}5334.765 \\
5334774.000\end{array}$ & -49.794 & -3.350 \\
\hline 610 & $\begin{array}{l}537.337 \\
537178.625\end{array}$ & $\begin{array}{l}5334.723 \\
5334731.000\end{array}$ & 83.075 & -6.257 \\
\hline 611 & $\begin{array}{l}562.059 \\
562061.875\end{array}$ & $\begin{array}{l}5325.653 \\
5325676.000\end{array}$ & 20.949 & -11.303 \\
\hline 612 & $\begin{array}{l}555.858 \\
555858.125\end{array}$ & $\begin{array}{l}5325.603 \\
5325612.000\end{array}$ & 1.787 & -0.953 \\
\hline 613 & $\begin{array}{l}549.650 \\
549654.312\end{array}$ & $\begin{array}{l}5325.553 \\
5325555.000\end{array}$ & -25.390 & 2.327 \\
\hline 614 & $\begin{array}{l}543.445 \\
543442.625\end{array}$ & $\begin{array}{l}5325.503 \\
5325505.000\end{array}$ & -40.794 & -1.359 \\
\hline 615 & $\begin{array}{l}537.347 \\
537238.812\end{array}$ & $\begin{array}{l}5325.454 \\
5325461.000\end{array}$ & 43.082 & -10.122 \\
\hline 616 & $\begin{array}{l}562.159 \\
562162.000\end{array}$ & $\begin{array}{l}5316.419 \\
5316418.000\end{array}$ & & 8.386 \\
\hline 617 & 555.947 & 5316.365 & 32.127 & 0.200 \\
\hline & 555948.312 & 5316354.000 & 10.867 & 14.311 \\
\hline 618 & $\begin{array}{l}549.729 \\
549734.375\end{array}$ & $\begin{array}{l}5316.310 \\
5316297.000\end{array}$ & -15.090 & 13.190 \\
\hline
\end{tabular}




\section{Reaion 6-Continued}

Scale $(X, Y)=(1003.621,1000.530)$ Translation $=(4007.221,-3149.250)$

Rotation (degrees) $=(0.065)$ RMS Error (input, output) $=(0.043,43.030)$

\begin{tabular}{|c|c|c|c|c|}
\hline Tic-ID & $\begin{array}{l}\text { Input } x \\
\text { output } x\end{array}$ & $\begin{array}{l}\text { Input y } \\
\text { output y }\end{array}$ & $x$ error & y error \\
\hline \multirow[t]{2}{*}{619} & 543.513 & 5316.256 & & \\
\hline & 543512.688 & 5316246.000 & -31.677 & 6.084 \\
\hline \multirow[t]{2}{*}{620} & 537.357 & 5316.202 & & \\
\hline & 537298.875 & 5316203.000 & 3.176 & -8.469 \\
\hline \multirow[t]{2}{*}{621} & 562.260 & 5307.157 & & \\
\hline & 562262.000 & 5307159.000 & 43.778 & 0.175 \\
\hline \multirow[t]{2}{*}{622} & 556.035 & 5307.104 & & \\
\hline & 556038.312 & 5307095.000 & 20.385 & 7.231 \\
\hline \multirow[t]{2}{*}{623} & 549.809 & 5307.050 & & \\
\hline & 549814.375 & 5307038.000 & -4.555 & 7.270 \\
\hline \multirow[t]{2}{*}{624} & 543.582 & 5306.997 & & \\
\hline & 543582.688 & 5306988.000 & -22.393 & 0.303 \\
\hline \multirow[t]{2}{*}{625} & 537.366 & 5306.944 & & \\
\hline & 537358.875 & 5306944.000 & -36.653 & -12.559 \\
\hline
\end{tabular}


Region 7

Scale $(X, Y)=(999.971,1000.050)$ Translation $=(512836.826,5280839.638)$

Rotation (degrees) $=(0.000)$ RMS Error (input, output) $=(0.014,13.647)$

\begin{tabular}{|c|c|c|c|c|}
\hline Tic-ID & $\begin{array}{l}\text { input } x \\
\text { output } x\end{array}$ & $\begin{array}{l}\text { input y } \\
\text { output y }\end{array}$ & $x$ error & y error \\
\hline \multirow[t]{2}{*}{701} & 5.857 & 21.382 & & \\
\hline & 518694.500 & 5302219.000 & -0.571 & 3.096 \\
\hline \multirow[t]{2}{*}{702} & -0.373 & 21.372 & & \\
\hline & 512465.594 & 5302202.000 & -2.042 & 10.582 \\
\hline \multirow[t]{2}{*}{703} & -6.605 & 21.362 & & \\
\hline & 506228.812 & 5302192.000 & 3.138 & 11.066 \\
\hline \multirow[t]{2}{*}{704} & -12.836 & 21.351 & & \\
\hline & 500000.000 & 5302189.000 & 0.897 & 4.552 \\
\hline \multirow[t]{2}{*}{705} & -19.068 & 21.341 & & \\
\hline & 493771.188 & 5302192.000 & -1.348 & -7.963 \\
\hline \multirow[t]{2}{*}{706} & 5.887 & 12.119 & & \\
\hline & 518724.406 & 5292960.000 & -0.435 & -1.294 \\
\hline \multirow[t]{2}{*}{707} & -0.353 & 12.102 & & \\
\hline & 512485.594 & 5292944.000 & -2.021 & -1.355 \\
\hline \multirow[t]{2}{*}{708} & -6.595 & 12.086 & & \\
\hline & 506238.812 & 5292934.000 & 3.096 & -7.420 \\
\hline \multirow[t]{2}{*}{709} & -12.836 & 12.069 & & \\
\hline & 500000.000 & 5292930.000 & 0.817 & -19.483 \\
\hline \multirow[t]{2}{*}{710} & -19.078 & 12.052 & & \\
\hline & 493761.188 & 5292934.000 & -1.480 & -39.547 \\
\hline \multirow[t]{2}{*}{711} & 5.917 & 2.845 & & \\
\hline & 518754.312 & 5283692.000 & -0.263 & -7.652 \\
\hline \multirow[t]{2}{*}{712} & -0.333 & 2.842 & & \\
\hline & 512505.594 & 5283675.000 & -2.019 & 6.623 \\
\hline \multirow[t]{2}{*}{713} & -6.585 & 2.838 & & \\
\hline & 506248.812 & 5283665.000 & 3.022 & 13.897 \\
\hline \multirow[t]{2}{*}{714} & -12.836 & 2.835 & & \\
\hline & 500000.000 & 5283661.000 & 0.738 & 15.172 \\
\hline \multirow[t]{2}{*}{715} & -19.088 & 2.832 & & \\
\hline & 493751.188 & 5283665.000 & -1.537 & 8.446 \\
\hline
\end{tabular}




\section{Region 7 -Continued}

Scale $(X, Y)=(999.971,1000.050)$ Translation $=(512836.826,5280839.638)$

Rotation (degrees) $=(0.000)$ RMS Error (input, output) $=(0.014,13.647)$

\begin{tabular}{|c|c|c|c|c|}
\hline TIC-ID & $\begin{array}{l}\text { Input } x \\
\text { output } x\end{array}$ & $\begin{array}{l}\text { input y } \\
\text { output y }\end{array}$ & $x$ error & y error \\
\hline \multirow[t]{2}{*}{716} & 5.947 & -6.403 & & \\
\hline & 518784.188 & 5274434.000 & -0.144 & 1.573 \\
\hline \multirow[t]{2}{*}{717} & -0.313 & -6.410 & & \\
\hline & 512525.500 & 5274417.000 & -1.942 & 12.452 \\
\hline \multirow[t]{2}{*}{718} & -6.575 & -6.417 & & \\
\hline & 506258.688 & 5274407.000 & 3.081 & 16.329 \\
\hline \multirow[t]{2}{*}{719} & -12.836 & -6.423 & & \\
\hline & 500000.000 & 5274403.000 & 0.659 & 14.206 \\
\hline \multirow[t]{2}{*}{720} & -19.098 & -6.430 & & \\
\hline & 493741.312 & 5274407.000 & -1.765 & 4.084 \\
\hline \multirow[t]{2}{*}{721} & 5.978 & -15.691 & & \\
\hline & 518814.000 & 5265176.000 & 0.168 & -29.227 \\
\hline \multirow[t]{2}{*}{722} & -0.293 & -15.691 & & \\
\hline & 512545.406 & 5265159.000 & -1.801 & -11.550 \\
\hline \multirow[t]{2}{*}{723} & -6.565 & -15.691 & & \\
\hline & 506268.688 & 5265149.000 & 3.037 & -0.873 \\
\hline \multirow[t]{2}{*}{724} & -12.836 & -15.691 & & \\
\hline & 500000.000 & 5265145.000 & 0.580 & 3.804 \\
\hline \multirow[t]{2}{*}{725} & -19.108 & -15.691 & & \\
\hline & 493731.312 & 5265149.000 & -1.867 & 0.481 \\
\hline
\end{tabular}


Region 8

Scale $(X, Y)=(999.897,999.510) \mathrm{D}$ Translation $=(535837.952,5296823.247)$

Rotation (degrees) $=(0.006) \mathrm{D}$ RMS Error (input, output) $=(0.012,11.846)$

\begin{tabular}{|c|c|c|c|c|}
\hline TIC-ID & $\begin{array}{l}\text { input } x \\
\text { output } x\end{array}$ & $\begin{array}{l}\text { input y } \\
\text { output y }\end{array}$ & $x$ error & y error \\
\hline \multirow[t]{2}{*}{801} & 23.316 & 10.284 & & \\
\hline & 559154.125 & 5307126.000 & -1.816 & -16.562 \\
\hline \multirow[t]{2}{*}{802} & 17.088 & 10.242 & & \\
\hline & 552922.375 & 5307066.000 & 2.437 & -0.408 \\
\hline \multirow[t]{2}{*}{803} & 10.860 & 10.200 & & \\
\hline & 546698.625 & 5307012.000 & -0.713 & 9.749 \\
\hline \multirow[t]{2}{*}{804} & 4.632 & 10.158 & & \\
\hline & 540474.812 & 5306965.000 & -3.849 & 12.906 \\
\hline \multirow[t]{2}{*}{805} & -1.591 & 10.116 & & \\
\hline & 534243.000 & 5306925.000 & 4.751 & 9.090 \\
\hline \multirow[t]{2}{*}{806} & -7.821 & 10.074 & & \\
\hline & 528019.188 & 5306891.000 & -0.241 & -0.766 \\
\hline \multirow[t]{2}{*}{807} & -14.045 & 10.032 & & \\
\hline & 521795.406 & 5306864.000 & -0.428 & -17.588 \\
\hline \multirow[t]{2}{*}{808} & 23.412 & 1.014 & & \\
\hline & 559249.125 & 5297857.000 & -1.116 & -12.894 \\
\hline \multirow[t]{2}{*}{809} & 17.173 & 0.971 & & \\
\hline & 553007.312 & 5297797.000 & 1.947 & 2.541 \\
\hline \multirow[t]{2}{*}{810} & 10.937 & 0.929 & & \\
\hline & 546773.625 & 5297743.000 & 0.056 & 11.998 \\
\hline \multirow[t]{2}{*}{811} & 4.699 & 0.886 & & \\
\hline & 540539.812 & 5297696.000 & -3.628 & 14.442 \\
\hline \multirow[t]{2}{*}{812} & -1.536 & 0.844 & & \\
\hline & 534298.000 & 5297656.000 & 3.760 & 9.908 \\
\hline \multirow[t]{2}{*}{813} & -7.776 & 0.801 & & \\
\hline & 528064.188 & 5297622.000 & -1.060 & -0.657 \\
\hline \multirow[t]{2}{*}{814} & -14.009 & 0.758 & & \\
\hline & 521830.406 & 5297595.000 & -0.242 & -18.181 \\
\hline \multirow[t]{2}{*}{815} & 23.509 & -8.256 & & \\
\hline & 559343.875 & 5288599.000 & -0.168 & -20.110 \\
\hline
\end{tabular}




\section{Region 8 - Continued}

Scale $(X, Y)=(999.897,999.510) \mathrm{D}$ Translation $=(535837.952,5296823.247)$

Rotation (degrees) $=(0.006) \mathrm{D}$ RMS Error (input, output) $=(0.012,11.846)$

\begin{tabular}{|c|c|c|c|c|}
\hline Tic-1D & $\begin{array}{l}\text { input } x \\
\text { output } x\end{array}$ & $\begin{array}{l}\text { input y } \\
\text { output y }\end{array}$ & $x$ error & y error \\
\hline \multirow[t]{2}{*}{816} & 17.258 & -8.296 & & \\
\hline & 553092.125 & 5288539.000 & 1.557 & -2.788 \\
\hline \multirow[t]{2}{*}{817} & $\quad 11.013$ & -8.337 & & \\
\hline & 546848.375 & 5288485.000 & 1.032 & 8.574 \\
\hline \multirow[t]{2}{*}{818} & 4.765 & -8.378 & & \\
\hline & 540604.625 & 5288438.000 & -3.275 & 12.911 \\
\hline \multirow[t]{2}{*}{819} & -1.482 & -8.419 & & \\
\hline & 534352.812 & 5288398.000 & 2.895 & 10.264 \\
\hline \multirow[t]{2}{*}{820} & -7.731 & -8.459 & & \\
\hline & 528109.125 & 5288364.000 & -1.878 & 1.597 \\
\hline \multirow[t]{2}{*}{821} & -13.973 & -8.500 & & \\
\hline & 521865.312 & 5288337.000 & -0.022 & -14.025 \\
\hline
\end{tabular}




\section{Region 9}

Scale $(X, Y)=(1000.012,999.041)$ Translation $=(535837.543,5274828.555)$

Rotation (degrees) $=(0.007)$ RMS Error (input, output) $=(0.013,13.448)$

\begin{tabular}{|c|c|c|c|c|}
\hline TIC-ID & $\begin{array}{l}\text { input } x \\
\text { output } x\end{array}$ & $\begin{array}{l}\text { input y } \\
\text { output y }\end{array}$ & $x$ error & y error \\
\hline \multirow[t]{2}{*}{901} & 20.423 & 9.102 & & \\
\hline & 556262.875 & 5283934.000 & -0.464 & -8.228 \\
\hline \multirow[t]{2}{*}{902} & 14.176 & 9.059 & & \\
\hline & 550014.125 & 5283877.000 & 0.645 & 4.966 \\
\hline \multirow[t]{2}{*}{903} & 7.921 & 9.017 & & \\
\hline & 543757.375 & 5283826.000 & 2.657 & 12.110 \\
\hline \multirow[t]{2}{*}{904} & 1.668 & 8.974 & & \\
\hline & 537508.625 & 5283782.000 & -2.073 & 12.262 \\
\hline \multirow[t]{2}{*}{905} & -4.582 & 8.931 & & \\
\hline & 531259.875 & 5283746.000 & -3.176 & 4.440 \\
\hline \multirow[t]{2}{*}{906} & -10.834 & 8.889 & & \\
\hline & 525003.125 & 5283715.000 & 1.257 & -8.400 \\
\hline \multirow[t]{2}{*}{907} & -17.083 & 8.846 & & \\
\hline & 518754.312 & 5283692.000 & 1.376 & -29.214 \\
\hline \multirow[t]{2}{*}{908} & 20.515 & -0.170 & & \\
\hline & 556352.500 & 5274676.000 & -0.046 & -13.260 \\
\hline \multirow[t]{2}{*}{909} & 14.257 & -0.210 & & \\
\hline & 550093.812 & 5274619.000 & 0.376 & 3.277 \\
\hline \multirow[t]{2}{*}{910} & 7.991 & -0.249 & & \\
\hline & 543827.125 & 5274568.000 & 1.252 & 13.765 \\
\hline \multirow[t]{2}{*}{911} & 1.730 & -0.288 & & \\
\hline & 537568.375 & 5274524.000 & -1.326 & 17.283 \\
\hline \multirow[t]{2}{*}{912} & -4.531 & -0.327 & & \\
\hline & 531309.688 & 5274487.000 & -3.323 & 13.805 \\
\hline \multirow[t]{2}{*}{913} & -10.792 & -0.366 & & \\
\hline & 525042.875 & 5274457.000 & 2.182 & 3.322 \\
\hline \multirow[t]{2}{*}{914} & -17.053 & -0.405 & & \\
\hline & 518784.188 & 5274434.000 & 0.440 & -14.154 \\
\hline \multirow[t]{2}{*}{915} & 20.606 & -9.453 & & \\
\hline & 556441.875 & 5265418.000 & 0.728 & -29.166 \\
\hline
\end{tabular}




\section{Region 9-Continued}

Scale $(X, Y)=(1000.012,999.041)$ Translation $=(535837.543,5274828.555)$

Rotation (degrees) $=(0.007)$ RMS Error (input, output) $=(0.013,13.448)$

\begin{tabular}{|c|c|c|c|c|}
\hline TIC-ID & $\begin{array}{l}\text { input } x \\
\text { output } x\end{array}$ & $\begin{array}{l}\text { input y } \\
\text { output y }\end{array}$ & $x$ error & y error \\
\hline \multirow[t]{2}{*}{916} & 14.337 & -9.489 & & \\
\hline & 550173.312 & 5265361.000 & 0.384 & -8.951 \\
\hline \multirow[t]{2}{*}{917} & 8.060 & -9.524 & & \\
\hline & 543896.688 & 5265310.000 & 0.110 & 5.217 \\
\hline \multirow[t]{2}{*}{918} & 1.791 & -9.560 & & \\
\hline & 537628.000 & 5265267.000 & -0.389 & 11.430 \\
\hline \multirow[t]{2}{*}{919} & -4.480 & -9.595 & & \\
\hline & 531359.375 & 5265230.000 & -3.294 & 11.629 \\
\hline \multirow[t]{2}{*}{920} & -10.750 & -9.631 & & \\
\hline & 525082.688 & 5265199.000 & 3.086 & 5.835 \\
\hline \multirow[t]{2}{*}{921} & -17.023 & -9.666 & & \\
\hline & 518814.000 & 5265176.000 & -0.405 & -7.969 \\
\hline
\end{tabular}


Region 10

Scale $(X, Y)=(999.923,999.280)$ Translation $=(504836.908,5243828.240)$

Rotation (degrees) $=(0.001)$ RMS Error (input, output) $=(0.012,12.324)$

\begin{tabular}{|c|c|c|c|c|}
\hline Tic-1D & $\begin{array}{l}\text { input } x \\
\text { output } x\end{array}$ & $\begin{array}{l}\text { input y } \\
\text { output y }\end{array}$ & $x$ error & y error \\
\hline \multirow[t]{2}{*}{1001} & 20.289 & 12.095 & & \\
\hline & 525122.375 & 5255931.000 & 1.879 & -18.168 \\
\hline \multirow[t]{2}{*}{1002} & 14.005 & 12.088 & & \\
\hline & 518843.812 & 5255907.000 & -3.579 & -0.387 \\
\hline \multirow[t]{2}{*}{1003} & 7.727 & 12.081 & & \\
\hline & 512565.312 & 5255891.000 & -2.476 & 9.400 \\
\hline \multirow[t]{2}{*}{1004} & 1.444 & 12.075 & & \\
\hline & 506278.594 & 5255880.000 & 2.157 & 14.183 \\
\hline \multirow[t]{2}{*}{1005} & -4.836 & 12.068 & & \\
\hline & 500000.000 & 5255877.000 & 1.339 & 10.968 \\
\hline \multirow[t]{2}{*}{1006} & -11.119 & 12.061 & & \\
\hline & 493721.406 & 5255880.000 & -3.108 & 1.750 \\
\hline \multirow[t]{2}{*}{1007} & -17.399 & 12.055 & & \\
\hline & 487434.812 & 5255891.000 & 3.839 & -15.465 \\
\hline \multirow[t]{2}{*}{1008} & 20.329 & 2.837 & & \\
\hline & 525162.125 & 5246673.000 & 2.437 & -11.597 \\
\hline \multirow[t]{2}{*}{1009} & 14.035 & 2.828 & & \\
\hline & 518873.594 & 5246650.000 & -2.883 & 2.809 \\
\hline \multirow[t]{2}{*}{1010} & 7.747 & 2.819 & & \\
\hline & 512585.094 & 5246633.000 & -2.064 & 11.223 \\
\hline \multirow[t]{2}{*}{1011} & 1.454 & 2.810 & & \\
\hline & 506288.500 & 5246623.000 & 2.717 & 12.632 \\
\hline \multirow[t]{2}{*}{1012} & -4.836 & 2.800 & & \\
\hline & 500000.000 & 5246619.000 & 1.399 & 8.043 \\
\hline \multirow[t]{2}{*}{1013} & -11.130 & 2.791 & & \\
\hline & 493711.500 & 5246623.000 & -3.556 & -4.550 \\
\hline \multirow[t]{2}{*}{1014} & -17.421 & 2.782 & & \\
\hline & 487414.906 & 5246633.000 & 1.850 & -23.141 \\
\hline \multirow[t]{2}{*}{1015} & 20.370 & -6.436 & & \\
\hline & 525201.688 & 5237416.000 & 3.247 & -20.874 \\
\hline
\end{tabular}




\section{Region 10 -Continued}

Scale $(X, Y)=(999.923,999.280)$ Translation $=(504836.908,5243828.240)$

Rotation (degrees) $=(0.001)$ RMS Error (input, output) $=(0.012,12.324)$

\begin{tabular}{|c|c|c|c|c|}
\hline Tic-ID & $\begin{array}{l}\text { input } x \\
\text { output } x\end{array}$ & $\begin{array}{l}\text { input y } \\
\text { output y }\end{array}$ & $x$ error & y error \\
\hline \multirow[t]{2}{*}{1016} & 14.065 & -6.442 & & \\
\hline & 518903.312 & 5237392.000 & -2.093 & -2.284 \\
\hline \multirow[t]{2}{*}{1017} & 7.767 & -6.448 & & \\
\hline & 512604.906 & 5237375.000 & -1.675 & 9.310 \\
\hline \multirow[t]{2}{*}{1018} & 1.465 & -6.454 & & \\
\hline & 506298.406 & 5237365.000 & 3.275 & 13.901 \\
\hline \multirow[t]{2}{*}{1019} & -4.836 & -6.460 & & \\
\hline & 500000.000 & 5237362.000 & 1.473 & 11.493 \\
\hline \multirow[t]{2}{*}{1020} & -11.140 & -6.466 & & \\
\hline & 493701.594 & 5237365.000 & -3.988 & 3.082 \\
\hline \multirow[t]{2}{*}{1021} & -17.443 & -6.472 & & \\
\hline & 487395.094 & 5237375.000 & -0.190 & -12.328 \\
\hline
\end{tabular}




\section{Region 11}

Scale $(X, Y)=(1000.320,996.613)$ Translation $=(540837.890,5241875.240)$

Rotation (degrees) $=(0.029)$ RMS Error (input, output) $=(0.062,61.771)$

\begin{tabular}{|c|c|c|c|c|}
\hline Tic-ID & $\begin{array}{l}\text { input } x \\
\text { output } x\end{array}$ & $\begin{array}{l}\text { input y } \\
\text { output } y\end{array}$ & $x$ error & y error \\
\hline \multirow[t]{2}{*}{1101} & 9.326 & 18.892 & & \\
\hline & 550213.125 & 5260727.000 & -37.059 & -2.922 \\
\hline \multirow[t]{2}{*}{1102} & 3.100 & 18.849 & & \\
\hline & 543931.375 & 5260676.000 & 17.052 & -8.376 \\
\hline \multirow[t]{2}{*}{1103} & -3.179 & 18.806 & & \\
\hline & 537657.875 & 5260632.000 & 9.383 & -21.315 \\
\hline \multirow[t]{2}{*}{1104} & -9.453 & 18.763 & & \\
\hline & 531384.312 & 5260595.000 & 6.884 & -41.207 \\
\hline \multirow[t]{2}{*}{1105} & -15.734 & 18.720 & & \\
\hline & 525102.625 & 5260565.000 & 5.288 & -68.166 \\
\hline \multirow[t]{2}{*}{1106} & 9.424 & 9.626 & & \\
\hline & 550292.500 & 5251469.000 & -22.558 & 20.963 \\
\hline \multirow[t]{2}{*}{1107} & 3.170 & 9.583 & & \\
\hline & 544000.875 & 5251418.000 & 12.971 & 15.249 \\
\hline \multirow[t]{2}{*}{1108} & -3.119 & 9.540 & & \\
\hline & 537717.375 & 5251375.000 & 5.231 & 1.216 \\
\hline \multirow[t]{2}{*}{1109} & -9.403 & 9.497 & & \\
\hline & 531433.812 & 5251338.000 & 2.632 & -18.770 \\
\hline \multirow[t]{2}{*}{1110} & -15.694 & 9.454 & & \\
\hline & 525142.312 & 5251307.000 & 1.734 & -44.813 \\
\hline \multirow[t]{2}{*}{1111} & 9.523 & 0.359 & & \\
\hline & 550371.812 & 5242201.000 & -7.976 & 52.933 \\
\hline \multirow[t]{2}{*}{1112} & 3.240 & 0.319 & & \\
\hline & 544070.312 & 5242150.000 & 8.945 & 49.948 \\
\hline \multirow[t]{2}{*}{1113} & -3.059 & 0.278 & & \\
\hline & 537776.875 & 5242107.000 & 1.055 & 38.818 \\
\hline \multirow[t]{2}{*}{1114} & -9.353 & 0.238 & & \\
\hline & 531483.375 & 5242070.000 & -1.717 & 21.732 \\
\hline \multirow[t]{2}{*}{1115} & -15.653 & 0.198 & & \\
\hline & 525181.875 & 5242039.000 & -1.735 & -1.399 \\
\hline
\end{tabular}




\section{Region 11 -Continued}

Scale $(X, Y)=(1000.320,996.613)$ Translation $=(540837.890,5241875.240)$

Rotation (degrees) $=(0.029)$ RMS Error (input, output) $=(0.062,61.771)$

\begin{tabular}{|c|c|c|c|c|}
\hline TIC-ID & $\begin{array}{l}\text { input } x \\
\text { output } x\end{array}$ & $\begin{array}{l}\text { input y } \\
\text { output y }\end{array}$ & $x$ error & y error \\
\hline \multirow[t]{2}{*}{1116} & 9.621 & -8.903 & & \\
\hline & 550451.000 & 5232943.000 & 6.672 & 80.699 \\
\hline \multirow[t]{2}{*}{1117} & 3.310 & -8.942 & & \\
\hline & 544139.625 & 5232893.000 & 5.014 & 78.003 \\
\hline \multirow[t]{2}{*}{1118} & -2.999 & -8.981 & & \\
\hline & 537836.312 & 5232849.000 & -3.076 & 69.321 \\
\hline \multirow[t]{2}{*}{1119} & -9.303 & -9.019 & & \\
\hline & 531532.875 & 5232812.000 & -6.010 & 53.681 \\
\hline \multirow[t]{2}{*}{1120} & -15.612 & -9.058 & & \\
\hline & 525221.500 & 5232782.000 & -5.267 & 31.005 \\
\hline \multirow[t]{2}{*}{1121} & 9.723 & -18.459 & & \\
\hline & 550530.125 & 5223686.000 & 24.356 & -184.990 \\
\hline \multirow[t]{2}{*}{1122} & 3.382 & -18.426 & & \\
\hline & 544208.812 & 5223636.000 & 2.786 & -116.816 \\
\hline \multirow[t]{2}{*}{1123} & -2.938 & -18.394 & & \\
\hline & 537895.625 & 5223592.000 & -6.162 & -54.701 \\
\hline \multirow[t]{2}{*}{1124} & -9.253 & -18.361 & & \\
\hline & 531582.312 & 5223555.000 & -9.828 & 0.399 \\
\hline \multirow[t]{2}{*}{1125} & -15.571 & -18.329 & & \\
\hline & 525261.000 & 5223524.000 & -8.615 & 49.507 \\
\hline
\end{tabular}


Scale $(X, Y)=(1000.100,999.424)$ Translation $=(506836.474,5220821.830)$

Rotation (degrees) $=(0.007)$ RMS Error (input, output) $=(0.012,12.295)$

\begin{tabular}{|c|c|c|c|c|}
\hline Tic-ID & $\begin{array}{l}\text { input } x \\
\text { output } x\end{array}$ & $\begin{array}{l}\text { input y } \\
\text { output y }\end{array}$ & $x$ error & y error \\
\hline \multirow[t]{2}{*}{1201} & 18.403 & 7.323 & & \\
\hline & 525241.312 & 5228148.000 & 1.247 & -17.005 \\
\hline \multirow[t]{2}{*}{1202} & 12.097 & 7.313 & & \\
\hline & 518933.000 & 5228124.000 & 2.802 & 0.255 \\
\hline \multirow[t]{2}{*}{1203} & 5.783 & 7.303 & & \\
\hline & 512624.688 & 5228107.000 & -3.317 & 10.506 \\
\hline \multirow[t]{2}{*}{1204} & -0.527 & 7.293 & & \\
\hline & 506308.312 & 5228097.000 & 1.793 & 13.760 \\
\hline \multirow[t]{2}{*}{1205} & -6.838 & 7.283 & & \\
\hline & 500000.000 & 5228094.000 & -1.859 & 10.014 \\
\hline \multirow[t]{2}{*}{1206} & -13.148 & 7.273 & & \\
\hline & 493691.688 & 5228097.000 & -3.552 & 0.270 \\
\hline \multirow[t]{2}{*}{1207} & -19.458 & 7.263 & & \\
\hline & 487375.312 & 5228107.000 & 2.495 & -16.474 \\
\hline \multirow[t]{2}{*}{1208} & 18.444 & -1.941 & & \\
\hline & 525280.812 & 5218891.000 & 1.652 & -18.132 \\
\hline \multirow[t]{2}{*}{1209} & 12.126 & -1.950 & & \\
\hline & 518962.594 & 5218867.000 & 0.988 & -0.689 \\
\hline \multirow[t]{2}{*}{1210} & 5.804 & -1.960 & & \\
\hline & 512644.406 & 5218850.000 & -3.197 & 9.751 \\
\hline \multirow[t]{2}{*}{1211} & -0.517 & -1.970 & & \\
\hline & 506318.188 & 5218840.000 & 1.305 & 13.191 \\
\hline \multirow[t]{2}{*}{1212} & -6.838 & -1.980 & & \\
\hline & 500000.000 & 5218837.000 & -2.918 & 9.631 \\
\hline \multirow[t]{2}{*}{1213} & -13.157 & -1.990 & & \\
\hline & 493681.812 & 5218840.000 & -4.354 & 0.073 \\
\hline \multirow[t]{2}{*}{1214} & -19.471 & -1.999 & & \\
\hline & 487355.594 & 5218850.000 & 7.305 & -16.479 \\
\hline \multirow[t]{2}{*}{1215} & 18.485 & -11.201 & & \\
\hline & 525320.188 & 5209634.000 & 2.169 & -16.076 \\
\hline
\end{tabular}




\section{Region 12 -Continued}

Scale $(X, Y)=(1000.100,999.424)$ Translation $=(506836.474 .5220821 .830)$

Rotation (degrees) $=(\mathbf{0 . 0 0 7 )}$ RMS Error (input, output) $=(0.012,12.295)$

\begin{tabular}{|c|c|c|c|c|}
\hline Tic-1D & $\begin{array}{l}\text { input } x \\
\text { output } x\end{array}$ & $\begin{array}{l}\text { input y } \\
\text { output y }\end{array}$ & $x$ error & y error \\
\hline \multirow[t]{2}{*}{1216} & 12.155 & -11.211 & & \\
\hline & 518992.188 & 5209610.000 & -0.833 & 0.869 \\
\hline \multirow[t]{2}{*}{1217} & 5.828 & -11.221 & & \\
\hline & 512664.188 & 5209593.000 & -0.704 & 10.818 \\
\hline \multirow[t]{2}{*}{1218} & -0.505 & -11.232 & & \\
\hline & 506328.000 & 5209583.000 & 2.405 & 13.761 \\
\hline \multirow[t]{2}{*}{1219} & -6.838 & -11.242 & & \\
\hline & 500000.000 & 5209580.000 & -3.979 & 9.703 \\
\hline \multirow[t]{2}{*}{1220} & -13.169 & -11.252 & & \\
\hline & 493672.000 & 5209583.000 & -7.426 & -0.353 \\
\hline \multirow[t]{2}{*}{1221} & -19.489 & -11.263 & & \\
\hline & 487335.812 & 5209593.000 & 7.978 & -17.396 \\
\hline
\end{tabular}




\section{APPENDIX E}

\section{ARC/INFO Hachure Processing Commands}

[ARC/INFO commands are capitalized; system prompts in standard text; user input italicized]

1. Execute RENODE on the data layer. This assigns each node a unique identification number.

2. Execute TURNTABLE on the DXF data layer to create a . TRN file (like the .AAT). One of the attributes in. TRN file is the azimuth of the arcs, which will be used later in selecting arcs with specific azimuth directions. In this example the 141 data layer (Dungeness crab) is used. TURNTABLE is a command in the optional NETWORK module of ARC.

3. To be able to relate to the .TRN file call INFO and redefine the NODE\# item to FNODE\# (from node) and TNODE\# (to node); so that the FNODE\# and TNODE\# items in the .AAT will match. The commands are as follows:

$\begin{array}{ll}\text { ARC: } \quad \text { info } & \\ \text { ENTER USER NAME> } & \text { aIC } \\ \text { ENTER COMMAND> } & \text { SEL L41.TRN } \\ \text { ENTER COMMAND> } & \text { REDEFINE } \\ \text { ENTER DATAFILE } & \text { DEFINITION } \\ \text { ITEM STARTING } & \text { COLUMN } 1 \\ \text { ITEM NAME> } & \text { FNODE\# } \\ \text { ITEM WIDTH> } & 4 \\ \text { ITEM OUTPUT WIDTH> } & 5 \\ \text { ITEM TYPE> } & B \\ & \\ \text { ENTER STARTING COLUMN> } & 1 \\ \text { ITEM NAME> } & \text { TNODE\# } \\ \text { ITEM WIDTH> } & 4 \\ \text { ITEM OUTPUT WIDTH> } & 5 \\ \text { ITEM TYPE> } & B \\ \text { ENTER STARTING COLUMN> } & <\text { hit retUrn> } \\ \text { ENTER COMMAND> } & \mathbf{Q} \text { STOP }\end{array}$


4. Start the ARCEDIT module and set up an environment that uniquely displays the 'from' and 'to' nodes on the arcs. This is accomplished by using the arrows option for the DRAWENVIRONMENT, which will allow you to distinguish the 'from' and 'to' nodes on the display screen. The RELATE command in ARCEDIT is also used to associate the editcoverage to the .TRN file. An example of these ARCEDIT start-up and relate sessions is as follows:

ARC: $\quad$ arcedit

Arcedit: display 4207 or 9999

Arcedit: editcoverage $L 41$

Arcedit: editfeature arc

Arcedit: drawenvironment arc arrows

Arcedit: relate add

What follows is the ARCEDIT: RELATE environment dialogue:

Relation name: turn

Table Identifier: L41.TRN

Database: info

INFO Item: fnode\#

Relate Column: fnode\#

Relate Type: Iinear

5. Use the "turn" relation just established to select all of the arcs for a given set of hachures. This is accomplished by determining the azimuth of a representative set of hachure arcs and then selecting all arcs with that azimuth value. The commands are:

Arcedit: select many

Select with the cursor the desired set of similar hachure arcs.

Arcedit: list turn//azimuth

Record TURN//AZIMUTH

224.233

In this example all arcs selected have the azimuth: 224.233 
6. Select all the arcs with that azimuth. Since azimuth is specified to three decimal places, it is best to select within a range of values. The command is:

Arcedit: select turn//azimuth $<225$ and turn//azimuth $>224$

7. To view what has been selected use the ARCEDIT command:

Arcedit: setdraw 2 (establishes a color, 2 = red) Arcedit: drawselect

8. In some cases, the direction of the arcs are reversed. Add to this selected set all azimuths in the reverse direction so a complete set of resource hachures can be obtained. In this example, the reverse of 224.233 is $44.233(224.233-180=$ 44.233). Therefore, execute the following command:

Arcedit: aselect turn//azimuth $>43$ and turn//azimuth $<46$

9. Put the selected features into a new data layer, such as "CRAB".

The command is:

Arcedit: put crab

10. Delete the hachures out of the original data-layer and repeat the procedure for the next resource. 